\title{
NYKYISEN JA TULEVAN ILMASTON SÄÄTIETOJA RAKENNUSFYSIKAALISIA LASKELMIA JA ENERGIALASKENNAN TESTIVUOTTA 2020 VARTEN
}

KIRSTI JYLHÄ

KIMMO RUOSTEENOJA

HERMAN BÖÖK ANDERS LINDFORS

PENTTI PIRINEN MIKKO LAAPAS ANTTI MÄKELÄ
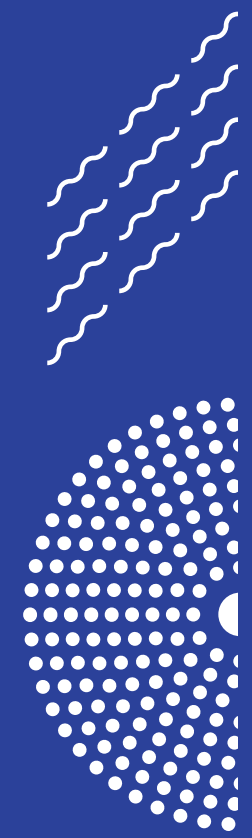
RAPORTTEJA

RAPPORTER

REPORTS

No. 2020: 6

$551.5,551.582,628.8$

$644.1,697.1$

Nykyisen ja tulevan ilmaston säätietoja

rakennusfysikaalisia laskelmia ja energialaskennan testivuotta 2020 varten

Kirsti Jylhä

Kimmo Ruosteenoja

Herman Böök

Anders Lindfors

Pentti Pirinen

Mikko Laapas

Antti Mäkelä

IImatieteen laitos

Meteorologiska Institutet

Finnish Meteorological Institute

Helsinki 2020 
IImatieteen laitos, raportteja 2020:6

ISBN 978-952-336-128-7

\section{ISSN 0782-6079}

DOI: https://doi.org/10.35614/isbn.9789523361287 
Julkaisija

IImatieteen laitos

(Erik Palménin aukio 1)

PL 503, 00101 Helsinki
Julkaisun sarja, numero ja raporttikoodi

Raportteja 2020:6

Päiväys: Marraskuu 2020

Kuva 4.2 päivitetty 29.9.2021

Tekijät

Kirsti Jylhä, Kimmo Ruosteenoja, Herman Böök,

Projektin nimi

RASMI

Anders Lindfors, Pentti Pirinen, Mikko Laapas ja Antti Mäkelä

\section{Nimeke}

Nykyisen ja tulevan ilmaston säätietoja rakennusfysikaalisia laskelmia ja energialaskennan testivuotta 2020

varten

\section{Tiivistelmä}

Ilmaston lämmetessä ja vesisateiden talvisinkin yleistyessä myös rakennetussa ympäristössä tulisi varautua muuttuviin sääolosuhteisiin. Tässä tutkimushankkeessa on luotu säähavaintoihin pohjautuvia tiedostoja, joita voidaan käyttää laskelmien pohjana arvioitaessa rakennusten energiantarvetta ja rakennusfysikaalista toimintaa nykyisessä ja tulevassa ilmastossa.

Aluksi tarkasteltiin neljän paikkakunnan (Vantaa, Jokioinen, Jyväskylä ja Sodankylä) säähavaintoja 30 vuoden pituiselta aikajaksolta 1989-2018; paikat edustavat kutakin neljää energialaskennan lämpötilavyöhykettä. Havaintojen pohjalta muodostettiin lämpötilan, ilman suhteellisen kosteuden, auringon kokonaissäteilyn, hajasäteilyn, sädettä vastaan kohtisuoralle pinnalle saapuvan suoran säteilyn, tuulen suunnan ja nopeuden sekä sademäärän tunnittaiset aikasarjat vuosille 1989-2018. Ilmastomallien ennustamien muutosten perusteella nämä aikasarjat muunnettiin kuvaamaan tulevaisuuden olosuhteita vuosina 2015-2044 (lähitulevaisuutta kuvaava vuoden 2030 ilmasto), 20352064 (vuosisadan puoliväliä kuvaava v. 2050 ilmasto) ja 2065-2094 (vuosisadan loppupuolen eli v. 2080 ilmasto). Kaikki nämä tulevaisuuden ilmaston sääaikasarjat muodostettiin erikseen kolmelle kasvihuonekaasuskenaariolle, joista RCP2.6 vastaa vähäistä, RCP4.5 kohtalaista ja RCP8.5 hyvin voimakasta ilmastonmuutosta.

Jakson 1989-2018 ilmastoa kuvaavista aikasarjoista haettiin kutakin 12 kuukautta kohti se vuosi, jona kyseisen kuukauden sääolot olivat vastanneet mahdollisimman hyvin keskimääräisiä ilmasto-oloja. Yhdistämällä nämä 12 kuukautta saatiin muodostettua kullekin energialaskennan vyöhykkeelle uusi rakennusten energialaskennan testivuosi TRY2020. Testivuotta kuvaavassa tiedostossa ovat mukana lämpötila, kosteus, auringon säteily (kokonaissäteily, suora säteily kohtisuoralle pinnalle ja hajasäteily) sekä tuulen suunta ja nopeus, mutta ei sademäärää. Samoja valittuja kuukausia käyttämällä muodostettiin vastaavat energialaskennan testivuodet myös kolmelle tulevaisuuden jaksolle, erikseen kullekin kasvihuonekaasuskenaariolle.

Aiemmin laadittuun testivuoteen TRY2012 verrattuna uusi testivuosi TRY2020 koostuu lämpötilavyöhykkeestä riippuen 7-11 uudesta tyyppikuukaudesta, kun taas loput kuukaudet ovat samoja kuin aikaisemmin. Vantaalla, Jyväskylässä ja Sodankylässä, joita tarkasteltiin molempia testivuosia muodostettaessa, TRY2020 on koko vuotta ajatellen $0.17-0.36^{\circ} \mathrm{C}$ lämpimämpi kuin TRY2012, vaikka joinakin yksittäisinä kuukausina se onkin viileämpi. Vuotuisen kokonaissäteilyn erot uuden ja aiemman testivuoden välillä ovat pieniä, mutta joinakin yksittäisinä kuukausina säteilymäärät kyllä poikkeavat melko selvästi.

Rakennusten energialaskennan testivuosien ohella koottiin rakennusfysikaalisten tarkastelujen vertailuja varten todellisen menneen vuoden (Jokioinen v. 2015) tunnittain mitatut säätiedot; näitä muokattiin myös kuvaamaan tulevaisuuden ajanjaksoja. Lisäksi hankkeessa tuotettuja 30-vuotisia nykyisen ja tulevaisuuden ilmaston säätietoja voidaan käyttää esimerkiksi aiemmin valittujen rakennusfysikaalisten testivuosien päivittämiseen.

Raportissa tarkasteltiin myös lämmitysjärjestelmien mitoitukseen käytettäviä kylmiä lämpötiloja sekä sitä, miten ilmastonmuutos vaikuttaa nykyään harvoin esiintyvien lämpötilojen, sademäärien ja tuulen nopeuksien yleisyyteen tulevaisuudessa.

Julkaisijayksikkö

Sään ja ilmastonmuutoksen vaikutustutkimus

\begin{tabular}{lll}
\hline Luokitus (UDK) & Asiasanat \\
$551.5,551.582,628.8,644.1,697.1$ & $\begin{array}{l}\text { Ilmasto, ilmastonmuutos, rakennusfysiikka, } \\
\text { lämmitysenergia, jäähdytysenergia }\end{array}$ & \\
\hline ISSN ja avainnimeke & ISBN & \\
0782-6079 Raportteja - Rapporter - Reports & $978-952-336-128-7$ & Sivumäärä \\
\hline DOI & Kieli & 81 \\
https://doi.org/10.35614/isbn.9789523361287 & suomi (tiivistelmä ruotsiksi ja englanniksi) & \\
\hline
\end{tabular}


Utgivare Meteorologiska institutet

(Erik Palméns plats 1)

PB 503, 00101 Helsingfors
Publikationens serie och nummer

Rapporter 2020:6

Datum: November 2020

Bild 4.2 uppdaterad 29.9.2021

Författare

Kirsti Jylhä, Kimmo Ruosteenoja, Herman Böök,

Projektnamn

RASMI

Anders Lindfors, Pentti Pirinen, Mikko Laapas ja Antti Mäkelä

Rubrik

Väderdata för det nuvarande och framtida klimatet för byggnadsfysikaliska beräkningar och typåret 2020 för energibehov

Sammandrag

Då det finska klimatet blir varmare och nederbörd i form av regn allt vanligare också vintertid, måste den bebyggda miljön vara beredd på förändringar i väderförhållanden. I detta arbete har vi framställt väderdata, som kan användas för att bedöma behovet av värme- och kylenergi samt byggnadsfysikalisk funktion i det nuvarande och framtida klimatet.

Väderdata samlades från fyra orter i Finland, Sodankylä, Jyväskylä, Jockis och Vanda, som representerar de olika temperaturzonerna för energiberäkning i byggnader. Timvis väderdata för åren 1989-2018 sammanställdes för följande väderparametrar: temperatur, relativ luftfuktighet, vindhastighet och riktning, global-, diffus- och direkt solstrålning samt nederbörd. De här trettioåriga tidsserierna omräknades för att representera det framtida klimatet i enlighet med simuleringar gjorda med klimatmodeller. Tre framtida perioder betraktades: 2015-2044 beskriver den nära framtiden, 2035-2064 mitten av seklet och 2065-2094 klimatet i slutet av seklet. Perioderna har namngetts enligt året i mitten av perioden, dvs. 2030, 2050 och 2080. Alla de tidsserier som representerar det framtida klimatet sammanställdes för tre växthusgasscenarier: RCP2.6 motsvarar små, RCP4.5 medelmåttliga och RCP8.5 mycket stora utsläpp.

Därefter användes de 30-åriga tidsserierna för att konstruera det nya testreferensåret, eller typåret, för efterfrågan av byggnadsenergi (TRY2020) för alla fyra termiska zoner. Typåret innehåller hela kalendermånader, som valts ut så att de rådande väderleksförhållandena under månaden motsvarar typiska långtida statistiska fördelningarna. I datafilerna för TRY2020 inkluderades alla ovannämnda väderparametrar förutom nederbörd. De valda månaderna användes också för att sammanställa typårsdata, som beskriver det framtida klimatet. Detta gjordes separat för alla tre framtida perioder och de tre växthusgasscenarierna.

Jämfört med det tidigare typåret TRY2012 består det nya typåret TRY2020 av 7-11 nya typmånader, beroende på den termiska zonen, medan resten av månaderna är desamma som i TRY2012. Då man granskar de tre orterna, för vilka båda typår finns tillgängliga, är den årliga medeltemperaturen i TRY2020 0,17-0,36 ${ }^{\circ} \mathrm{C}$ högre än i TRY2012, även om några enstaka månader är svalare. Den årliga summan av global solstrålning är nästan identisk i de två typåren, men under några enskilda månader skiljer strålningsmängden sig tydligt.

Förutom typåren för energiberäkningar, sammanställdes väderdata för ett historiskt år (Jockis 2015) som kan användas för exempelvis byggnadsfysiska studier. Även detta jämförelseår omräknades till att representera framtida förhållanden. Dessutom kan de 30-åriga tidsserier, som utarbetats i projektet, användas för att uppdatera tidigare byggnadsfysiska typår.

Rapporten undersöker också förekomsten av mycket låga temperaturer, som är relevanta för dimensioneringen av värmesystem. Dessutom granskade vi, hur den förväntade klimatförändringen inverkar på extrema temperaturer, nederbördsmängder och vindhastigheter i framtiden.

Publikationsenhet

Forskning av väder och klimatförändringens effekter

\begin{tabular}{lll}
\hline Klassificering (UDK) & Nyckelord \\
$551.5,551.582,628.8,644.1,697.1$ & $\begin{array}{l}\text { Klimat, klimatförändring, byggnadsfysik, testreferensår, } \\
\text { energi för uppvärmning och kylning av byggnader }\end{array}$ \\
\hline ISSN ja och serietitel & ISBN & Sidantal \\
0782-6079 Raportteja - Rapporter - Reports & $978-952-336-128-7$ & 81 \\
\hline DOI & Språk & finska (sammandrag också på svenska) \\
https://doi.org/10.35614/isbn.9789523361287 & &
\end{tabular}


Finnish Meteorological Institute (Erik Palménin aukio 1), P.O. BOX 503 FIN-00101 Helsinki
Series title and number

Reports 2020:6

Date: November 2020

Figure 4.2 updated 29.9.2021

Name of project

RASMI

Author(s)

Kirsti Jylhä, Kimmo Ruosteenoja, Herman Böök, Anders Lindfors, Pentti Pirinen, Mikko Laapas and Antti Mäkelä

Title

Weather data for building-physical studies and the building energy reference year 2020 in a changing climate

\section{Abstract}

As the Finnish climate becomes warmer and liquid precipitation events will be increasingly frequent even in winter, it is necessary to be prepared for changing weather conditions in the built-up environment. In this study, we have elaborated weather data files that can be utilized in assessing energy demand and physical functioning in buildings in the current and future climate.

Weather datasets were compiled for four measurement sites in Finland, Sodankylä, Jyväskylä, Jokioinen and Vantaa, each of them representing different thermal zones for building energy demand. The datasets, comprising years 1989-2018, contained the following variables at hourly resolution: temperature, relative humidity, wind speed and direction, total, diffuse and direct normal solar radiation and precipitation. The tridecadal datasets were transformed to represent future climate by modifying the hourly values of the weather variables in accordance with climate model projections. Three future periods were considered, 2015-2044 representing the immediate future, 2035-2064 mid-century and 2065-2094 the late century climate. Henceforth, the periods will be referred to according to the mid-point year, i.e., 2030, 2050 and 2080, respectively. All the time series representing future climate were compiled for three representative concentration pathways, RCP2.6 representing small, RCP4.5 medium and RCP8.5 very large greenhouse-gas emissions.

Next, the 30-year datasets were used to find for each of the twelve calendar months a "standard" month during which weather conditions have been as close as possible to typical long-term statistical distributions. These twelve months originating from different years were merged to create the new test reference year of building energy demand (TRY2020) for all four thermal zones. In the test reference year datasets, all the above-mentioned weather variables were included apart from precipitation. The months selected were likewise used to extract test reference year data from the data files representing future climate, separately for all three future periods and the three representative concentration pathways.

Compared to the previously-compiled test reference year TRY2012, the new reference year TRY2020 consists of 7-11 fresh months, depending on the thermal zone, the remaining months being the same as in TRY2012. Regarding the three measurement sites for which both references years are available, the annual mean temperature in TRY2020 is $0.17-0.36^{\circ} \mathrm{C}$ higher than in TRY2012, even though some individual months are cooler. The total annual solar radiation sum in the two test reference years is nearly identical, while some single months exhibit quite remarkable differences.

In addition to the test reference year for building energy demand, hourly measurements during a historical year (Jokioinen 2015) were collected for comparison purposes in building physical calculations. This comparison year data was also transformed to represent future climates. Moreover, the 30-year datasets elaborated in the project can be used to update previously-selected building physical test years for the Finnish climate.

The report likewise examines very cold temperatures relevant for the design of heating systems. As well, we explored how the projected climate change affects the future occurrence of temperature, precipitation and wind speed extremes.

\begin{tabular}{lll}
\hline $\begin{array}{l}\text { Publishing unit } \\
\text { Weather and Climate Change Impact Research }\end{array}$ \\
\hline \begin{tabular}{lll} 
Classification (UDK) & Keywords: \\
$551.5,551.582,628.8,644.1,697.1$ & $\begin{array}{l}\text { Climate, climate change, building physics, test reference year, } \\
\text { heating energy, cooling energy }\end{array}$ & \\
\hline ISSN and series title & ISBN & \\
$0782-6079$ Raportteja - Rapporter - Reports & ISBN 978-952-336-128-7 & Pages \\
\hline DOI & Language & 81 \\
https://doi.org/10.35614/isbn.9789523361287 & Finnish (abstract also in English) & \\
\hline
\end{tabular}
\end{tabular}




\section{Esipuhe}

Säätiedon merkitys rakennussuunnittelussa korostuu ilmaston muuttuessa. Tähän mennessä käytössä olleet rakennusten lämmitys- ja jäähdytysenergian kulutuksen laskentaa sekä sisäilmaston ja rakennusfysiikan tarkasteluja varten kehitetyt testivuodet pohjautuvat vuosien 1980-2009 säähavaintotietoihin. Testivuosien uudelleentarkastelua alettiin kaavailla Ympäristöministeriön ja Ilmatieteen laitoksen välillä vuonna 2018. Ajantasaistamisen tarpeeseen vaikuttivat tuoreimpien vuosien puuttuminen testivuosien pohjana olevista säätiedoista ja säähavaintojen käsittelyyn liittyvien tieteellisten menetelmien kehittyminen. Samalla ilmastomallit ovat kehittyneet ja kasvihuonekaasujen päästöjä kuvaavia skenaarioita on päivitetty. Lisäksi tutkimus on kasvattanut ymmärrystämme sään ääri-ilmiöiden esiintyvyydestä ja merkityksestä.

Hankkeen tavoitteena oli arvioida, millaisiin sääolosuhteisiin rakennetussa ympäristössä tulisi varautua ilmaston jatkuvasti muuttuessa. Tietoja voidaan ensinnäkin käyttää rakennusten vuotuisen lämmitys- ja jäähdytysenergian tarpeen sekä lämmitysjärjestelmien mitoitustehon laskemiseen. Toisena painopistealueena oli ilmastonmuutoksen vaikutusten huomioonottaminen sellaisten sääolojen esiintymisessä, jotka voivat aiheuttaa ongelmia sisäilman lämpö- ja kosteusolosuhteissa sekä häiritä rakennusten kosteusteknistä toimintaa. Ilmastonmuutoksen vaikutusta arvioitiin vertaamalla vuosien 2030, 2050 ja 2080 ilmastoa nykyisin vallitsevaan tilanteeseen. Erikseen tarkasteltiin rakennetun ympäristön kannalta merkityksellisiä sään ääriilmiöitä.

Hankkeen toteutti Ilmatieteen laitos Ympäristöministeriön rahoituksella. Laitoksen puolelta hankkeen vastuullisena johtajana toimi ryhmäpäällikkö FT Antti Mäkelä, vastuullisena päätutkijana dosentti FT Kirsti Jylhä ja muina tutkijoina FT Kimmo Ruosteenoja, FM Herman Böök, dosentti FT Anders Lindfors, FM Pentti Pirinen ja FM Mikko Laapas. Ympäristöministeriön puolelta hankkeen ohjausryhmään kuuluivat rakennusneuvos Jukka Bergman, rakennusneuvos Pekka Kalliomäki, yli-insinööri Katja Outinen sekä 1.6.2020 lähtien yli-insinööri Timo Lahti.

Hankkeen tuloksena syntynyttä, avoimesti saatavilla olevaa tietoa voidaan hyödyntää laajasti pohjatietona rakennusten energiankäyttöön, sisäilmastoon sekä rakenteiden rakennusfysikaaliseen toimintaan liittyvissä selvityksissä ja tutkimuksissa.

Juhani Damski

Kansliapäällikkö

Ympäristöministeriö 


\begin{abstract}
Alkusanat
Terveellinen ja tarkoituksenmukaisesti rakennettu ympäristö on yksi keskeisimmistä asioista nykyihmisen elämässä, sillä se vaikuttaa niin asumiseen, työntekoon kuin vapaa-ajan harrastuksiinkin. Ilmaston ennustetaan lämpenevän täällä Pohjolassa voimakkaammin kuin maapallolla keskimäärin. Näin ollen myös suomalaiset rakennukset joutuvat keskelle tätä muutosta.
\end{abstract}

Suomessa rakentamista säätelevät maankäyttö- ja rakennuslaki sekä siihen liittyvät Ympäristöministeriön rakennusmääräykset. Meidän kaikkien hyvinvoinnin ja turvallisuuden sekä ilmaston kannalta keskeisiä ovat etenkin rakenteiden lujuuteen, terveellisyyteen ja energiatehokkuuteen liittyvät määräykset. Energiatehokas rakentaminen myös omalta osaltaan hillitsee ilmastonmuutosta. Onneksi meillä Suomessa on jo pitkään hyödynnetty ajantasaista sää- ja ilmastotietoa rakennusmääräysten ja niihin liittyvien tutkimusten taustatietona. Esimerkiksi tekniikan alan tutkijat ovat voineet käyttää säätietoja osana rakennusten toiminnan mallinnusta.

Nyt päättynyt hanke ajoittui harmillisesti keskelle koronaviruksen aiheuttamia poikkeusoloja, jotka hakevat vertaistaan. Meille ilmastotutkijoille perinteisesti keskeiset keskustelu- ja suunnittelutuokiot tutkijatovereiden kesken vaihtuivat tiedonvaihtoon sähköpostien ja videopuheluiden välityksellä, jotka eivät pysty korvaamaan vuorovaikutusta kasvotusten. Tästä aiheutui matkan varrella ylimääräistä ja päällekkäistä työtä. Hankkeen päätösseminaari toteutettiin niin ikään videomuotoisena. Hyviäkin puolia etäyhteyksin toteutetusta seminaarista toki on: osallistua voi periaatteessa mistä päin maailmaa tahansa ilman matkustamista.

Ilmatieteen laitokselta tämän työn toteutukseen osallistui seitsemän tutkijaa seuraavin keskeisimmin tehtävin:

Kirsti Jylhä: Hankkeen päätutkija; raportin sekä tulostiedostojen pääasiallinen laatija.

Kimmo Ruosteenoja: Ilmastonmuutosta koskevat laskelmat ja selostukset.

Herman Böök ja Anders Lindfors: Nykyisen ilmaston auringonsäteilytietojen tuottaminen.

Pentti Pirinen: Säähavaintotietojen kerääminen ja täydentäminen; opastus.

Mikko Laapas: Ääriarvoanalyysit.

Antti Mäkelä: Hankkeen vastuullinen johtaja; raportin koostamisessa avustaminen.

Kiitämme Ilmatieteen laitoksen Havaintoyksikköä sen tarjoamasta avusta säähavaintoihin liittyvien tietojen täsmentämisessä, kansainvälisiä yhteisöjä satelliittihavaintojen ja ilmastonmuutosmallien tulosten saattamisesta tutkijoiden käyttöön, FM Matti Kämäräistä ns. harhankorjausten tekemisestä ilmastomallien vuorokautisiin tulostietoihin ja FT Ilari Lehtosta raportin tarkistamisesta. Erityisesti kiitämme tämän hankkeen rahoittajana toiminutta Ympäristöministeriötä. Tutkimuksen loppuvaiheessa työtä tehtiin myös Suomen Akatemian rahoittamassa HEATCLIM-hankkeessa (päätösnumero 329307).

Tässä hankkeessa saadut tulokset ovat koko suomalaisen yhteiskunnan käytettävissä. Mitä paremmin rakentaminen sopeutuu muuttuvaan ilmastoon, sitä paremmat edellytykset myös meillä pohjolan asukkailla on sopeutua muuttuviin olosuhteisiin. Lisäksi energiatehokas rakentaminen on osa ilmastonmuutoksen hillintää.

Helsingissä 28.10.2020

Antti Mäkelä

Ryhmäpäällikkö

Ilmatieteen laitos 


\section{Sisällysluettelo}

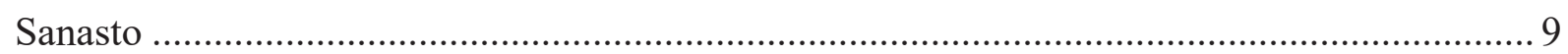

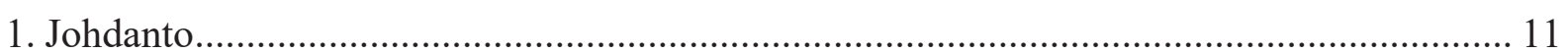

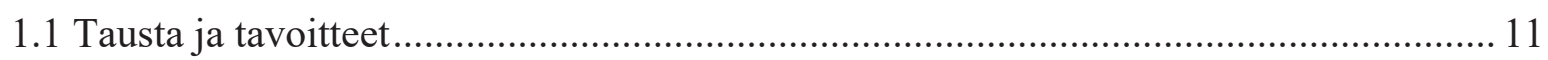

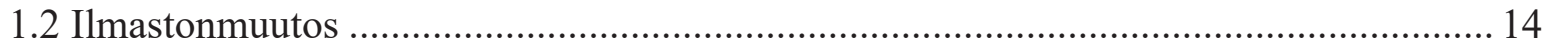

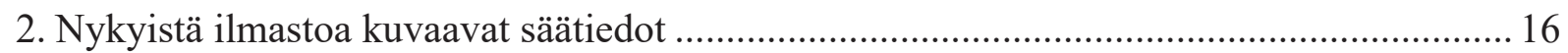

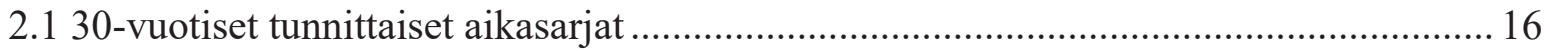

2.2 Rakennusten energialaskennan uudet testivuodet (TRY2020)..................................... 20

2.3 Vertailua käytössä olevaan energialaskennan testivuoteen (TRY2012) ........................ 22

2.4 Rakennusfysikaalisten tarkastelujen vertailuvuosi....................................................... 24

3. Tulevaisuuden ilmaston säätietojen arviointimenetelmät .................................................25

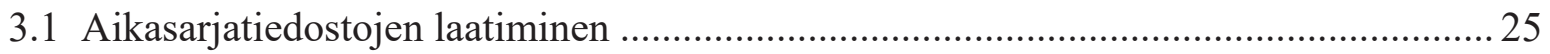

3.2 Ilmastosuureitten kuukausikeskiarvojen mutokset.................................................2 25

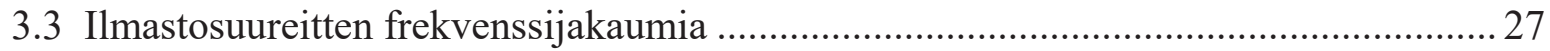

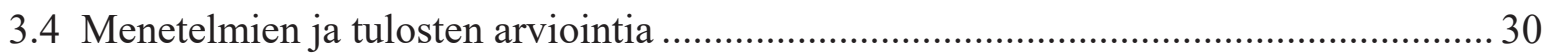

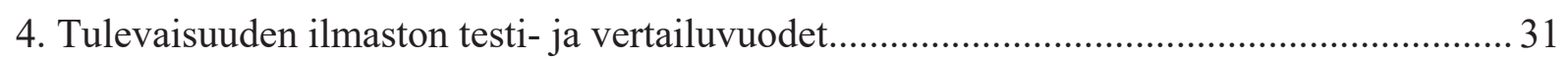

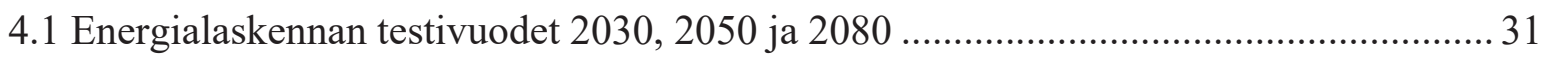

4.2 Rakennusfysikaalisten tarkastelujen vertailuvuodet 2030,2050 ja $2080 \ldots \ldots \ldots \ldots \ldots \ldots \ldots \ldots . . . .32$

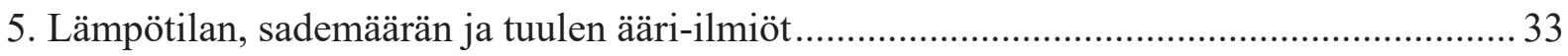

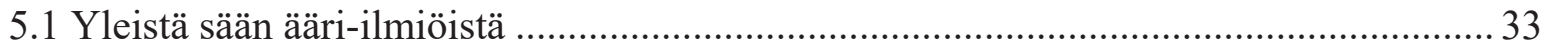

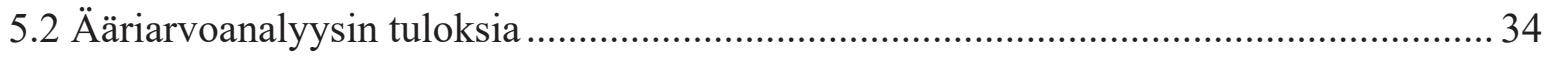

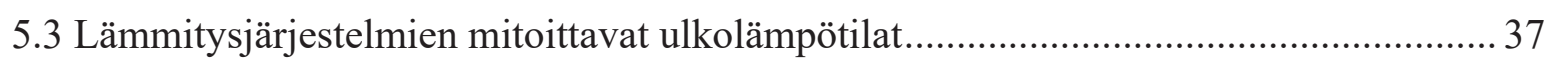

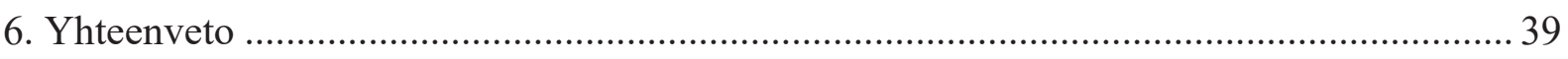

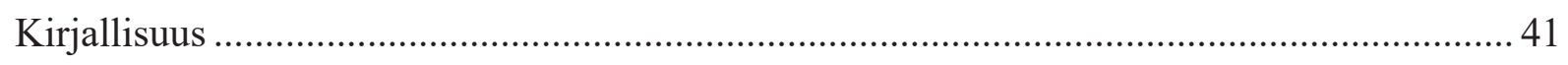

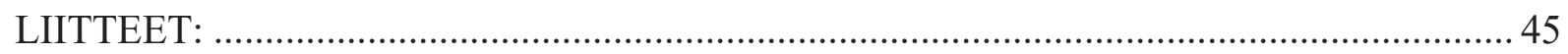

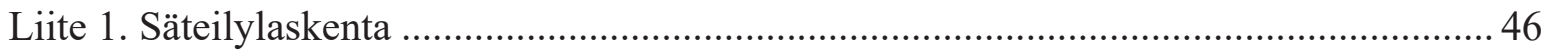

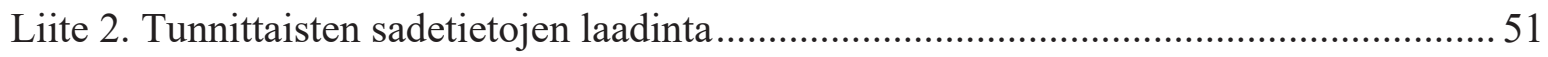

Liite 3. Energialaskennan testivuosien valinta ja lisävertailuja............................................ 64

Liite 4. Eri ilmastosuureitten muuntaminen kuvaamaan tulevaisuuden ilmastoa ................. 73

Liite 5. Ilmastosuureiden kuukausikeskiarvojen muutokset 30-vuotisista aikasarjatiedostoista .78

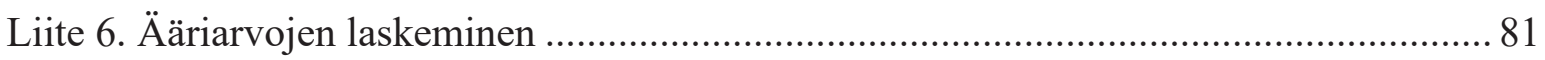




\section{Sanasto}

\begin{tabular}{|c|c|}
\hline $\begin{array}{l}\text { Automaattinen } \\
\text { sääasema }\end{array}$ & $\begin{array}{l}\text { Säähavaintoasema, jolla toimii Suomen sääolosuhteisiin sopiva } \\
\text { automaattinen havaintolaite kullekin havaintosuureelle erikseen. } \\
\text { Säähavainnot välitetään eteenpäin vähintään tunnin ja } \\
\text { tiheimmillään minuutin välein. }{ }^{1}\end{array}$ \\
\hline CMIP5 (Coupled & Lukuisten kansainvälisten ilmastomallinnusryhmien yhteisö, joka \\
\hline Model & koordinoi mallisimulaatioiden tekoa ja tulosten vertailua ja joka \\
\hline Intercomparison & tarjoaa kootusti ilmastomallien tuloksia muiden tutkijoiden \\
\hline Project Phase 5) & käyttöön. Tässä raportissa hyödynnetään 5 . vaiheen mallidataa. ${ }^{2}$ \\
\hline DHI (Diffuse & Auringon hajasäteily vaakasuoralle pinnalle (pinta-ala $1 \mathrm{~m}^{2}$ ) \\
\hline Horizontal Irradiance) & $\begin{array}{l}\text { ilmaistuna joko säteilytehona (yksikkö } \mathrm{W} / \mathrm{m}^{2} \text { ) tai tarkasteltavan } \\
\text { jakson aikana kertyneenä säteilysummana/-energiana (yksikkö } \\
\left.\mathrm{kWh} / \mathrm{m}^{2}\right) .^{3}\end{array}$ \\
\hline $\begin{array}{l}\text { DNI (Direct Normal } \\
\text { Irradiance) }\end{array}$ & $\begin{array}{l}\text { Auringon suora säteily aurinkoon nähden kohtisuoralle pinnalle } \\
\text { ilmaistuna säteilytehona (yksikkö } \mathrm{W} / \mathrm{m}^{2} \text { ) tai säteilysummana } \\
\left(\mathrm{kWh} / \mathrm{m}^{2}\right) .{ }^{3}\end{array}$ \\
\hline $\begin{array}{l}\text { GHI (Global } \\
\text { Horizontal Irradiance) }\end{array}$ & $\begin{array}{l}\text { Auringon kokonaissäteily vaakasuoralle pinnalle ilmaistuna } \\
\text { säteilytehona }\left(\text { yksikkö } \mathrm{W} / \mathrm{m}^{2}\right) \text { tai säteilysummana }\left(\mathrm{kWh} / \mathrm{m}^{2}\right){ }^{3}\end{array}$ \\
\hline Harvinainen sääilmiö & $\begin{array}{l}\text { Ilmatieteen laitoksen määritelmän mukaan harvemmin kuin } \\
\text { keskimäärin kerran } 10 \text { vuodessa esiintyvä sääilmiö. }{ }^{4}\end{array}$ \\
\hline Ilmasto & $\begin{array}{l}\text { Jonkin paikan säämuuttujien (lämpötila, sademäärä, tuulen } \\
\text { nopeus ja suunta, ilman kosteus jne.) mitatuista tai mallinne- } \\
\text { tuista arvoista laskettu pitkän ajan keskiarvo sekä vaihtelevai- } \\
\text { suus. Tarkastelujakson tyypillinen pituus on } 30 \text { vuotta. }^{5}\end{array}$ \\
\hline Ilmastomalli & $\begin{array}{l}\text { Ilmakehän, merten, kasvillisuuden, jäätiköiden ja lumen } \\
\text { vuorovaikutuksia kuvaavien mallien yhdistelmä, jolla } \\
\text { simuloidaan hetki hetkeltä esimerkiksi ilmakehän } \\
\text { kasvihuonekaasupitoisuuksien kasvun vaikutuksia ilmastoon. } \\
\text { Katso päästöskenaario. }\end{array}$ \\
\hline $\begin{array}{l}\text { IPCC (International } \\
\text { Panel on Climate } \\
\text { Change) }\end{array}$ & $\begin{array}{l}\text { YK:n alainen hallitustenvälinen ilmastonmuutospaneeli, joka } \\
\text { tuottaa arvioita meneillään olevasta ja tulevasta ilmastonmuutok- } \\
\text { sesta. }{ }^{6}\end{array}$ \\
\hline $\begin{array}{l}\text { Jäähdytysenergian } \\
\text { tarve }\end{array}$ & $\begin{array}{l}\text { Rakennuksen tilojen ja tuloilman jäähdyttämiseksi tarvittava } \\
\text { energia. }{ }^{7}\end{array}$ \\
\hline $\begin{array}{l}\text { Lämmitysenergian } \\
\text { tarve }\end{array}$ & $\begin{array}{l}\text { Rakennuksen tilojen, ilmanvaihdon ja lämpimän käyttöveden } \\
\text { lämmittämiseen tarvittava energia. }{ }^{8}\end{array}$ \\
\hline
\end{tabular}

\footnotetext{
${ }^{1}$ https://www.ilmatieteenlaitos.fi/saahavainnot

2 https://pcmdi.llnl.gov/mips/cmip5/

${ }^{3}$ https://www.ilmatieteenlaitos.fi/neuvoja-havaintosuureisiin

${ }^{4}$ https://www.ilmatieteenlaitos.fi/saa-on-harvoin-poikkeuksellinen

${ }^{5} \mathrm{https}: / /$ www.ilmatieteenlaitos.fi/ilmakeha-abc?term=Ilmasto

${ }^{6}$ https://www.ilmatieteenlaitos.fi/ipcc-ilmastopaneeli; https://www.ipcc.ch/

${ }^{7}$ https://www.finlex.fi/data/normit/37188-D3-2012_Suomi.pdf

${ }^{8}$ https://www.finlex.fi/fi/laki/alkup/2017/20171010\#Pidp447167344
} 


\begin{tabular}{|c|c|}
\hline $\begin{array}{l}\text { Manuaalinen } \\
\text { sääasema }\end{array}$ & $\begin{array}{l}\text { Manuaalisella säähavaintoasemalla havainnontekijä lukee } \\
\text { havaintolaitteiden lukemat ja tekee aistinvaraiset havainnot näky- } \\
\text { vyydestä, pilvisyydestä, vallitsevasta säästä ja maanpinnan laa- } \\
\text { dusta kahdeksan kertaa vuorokaudessa (katso synoptiset } \\
\text { säähavainnot). }{ }^{1}\end{array}$ \\
\hline $\begin{array}{l}\text { Mitoittava } \\
\text { ulkolämpötila }\end{array}$ & $\begin{array}{l}\text { Lämmitysjärjestelmän lämmitystehon mitoituksessa käytettävä } \\
\text { ulkolämpötila. Lämmitystehon mitoituksessa rakennuksen sisäi- } \\
\text { siä ja auringon aiheuttamia lämpökuormia ei oteta huomioon. }{ }^{7}\end{array}$ \\
\hline $\begin{array}{l}\text { Poikkeuksellinen } \\
\text { sääilmiö }\end{array}$ & $\begin{array}{l}\text { Ilmatieteen laitoksen määritelmän mukaan keskimäärin } 2-3 \\
\text { kertaa sadan vuoden aikana tai harvemmin esiintyvä sääilmiö. }{ }^{4}\end{array}$ \\
\hline Päästöskenaario & $\begin{array}{l}\text { Ihmiskunnan ilmakehään vapauttamien kasvihuonekaasujen } \\
\text { määrää ja pitoisuutta ilmakehässä kuvaavat vaihtoehtoiset } \\
\text { kehityskulut, joita käytetään arvioitaessa ilmaston muuttumista. } \\
\text { Nykyään käytössä ovat ns. RCP-skenaariot RCP2.6, RCP4.5, } \\
\text { RCP6.0 ja RCP8.5 (Representative Concentration Pathways), } \\
\text { jotka johtavat kuluvan vuosisadan loppuun mennessä tietynvah- } \\
\text { vuiseen säteilypakotteeseen }\left(2.6,4.5,6.0 \text { tai } 8.5 \mathrm{~W} / \mathrm{m}^{2}\right) . .^{9}\end{array}$ \\
\hline $\mathrm{RCP}$ & Katso päästöskenaario. \\
\hline $\begin{array}{l}\text { Synoptiset } \\
\text { säähavainnot } \\
\text { (synop-havainnot) }\end{array}$ & $\begin{array}{l}\text { Kansainvälisesti sovitut samanaikaisesti eri puolilla maapalloa } \\
\text { kolmen tunnin välein (kello } 00,03,06,09,12,15,18 \text { ja } 21 \text { UTC) } \\
\text { tehtävät säähavainnot ilmakehän lämpötilasta, paineesta, } \\
\text { kosteudesta ja muista ominaisuuksista. }\end{array}$ \\
\hline Testi & $\begin{array}{l}\text { Joltakin ilmastolliselta kaudelta (esim. menneeltä } 30 \text { vuoden } \\
\text { jaksolta) tiettyyn tarkoitukseen valittu vuoden pituinen } \\
\text { sääaineisto. Rakennusten energialaskennan testivuosi TRY kuvaa } \\
\text { tilastollisilta ominaisuuksiltaan mahdollisimman tyypillisiä } \\
\text { sääoloja. }{ }^{10} \text { Rakennusfysiikan testivuosi taas edustaa esimerkiksi } \\
\text { homeen kasvun ja kosteuden rakenteisiin tiivistymisen kannalta } \\
\text { ongelmallista vuotta. }{ }^{11}\end{array}$ \\
\hline TRY & Katso testivuosi. \\
\hline $\begin{array}{l}\text { Uusanalyysi } \\
\text { (reanalyysi) }\end{array}$ & $\begin{array}{l}\text { Säähavaintojen sekä sääennustemallin avulla tuotettu arvio ilma- } \\
\text { kehän hetkellisestä tilasta ajassa taaksepäin (usein maailman- } \\
\text { laajuisesti ja usean vuosikymmenen ajalta). Esimerkiksi ERA5- } \\
\text { uusanalyysi on tällainen. }{ }^{12}\end{array}$ \\
\hline Ääri-ilmiö & $\begin{array}{l}\text { Ilmakehätieteissä jokin harvinainen sääilmiö tai säämuuttujan } \\
\text { poikkeuksellisen iso tai pieni arvo. Tilanteesta riippuen ääri- } \\
\text { ilmiö voidaan määrittää eri tavoin (maksimi/minimi, } \\
\text { esiintymistodennäköisyys, toistuvuus, voimakkuus jne). } \\
\text { Esimerkki lämpötilan ääri-ilmiöstä on Suomen nykyinen } \\
\text { lämpötilaennätys }+37.2^{\circ} \mathrm{C} \text { vuodelta } 2010 .{ }^{13}\end{array}$ \\
\hline
\end{tabular}

\footnotetext{
${ }^{9} \mathrm{https}: / /$ sedac.ciesin.columbia.edu/ddc/ar5_scenario_process/RCPs.html

${ }^{10} \mathrm{https}: / /$ www.iso.org/standard/41371.html

${ }^{11} \mathrm{https} / /$ research.tuni.fi/rakennusfysiikka/kosteusanalysointimenetelma/rakennusfysikaaliset-testivuodet/

$12 \mathrm{https} / / /$ climate.copernicus.eu/climate-reanalysis

${ }^{13} \mathrm{https} / / /$ www.ilmatieteenlaitos.fi/saaennatyksia
} 


\section{Johdanto}

\subsection{Tausta ja tavoitteet}

Ilmaston lämmetessä ja vesisateiden yleistyessä lumisateiden kustannuksella myös rakennetussa ympäristössä tulisi varautua muuttuviin sääolosuhteisiin. Tämän tutkimustyön tavoitteena on tuottaa uutta tutkimustietoa Suomen ilmaston muuttumisen vaikutuksesta sellaisiin sääoloihin, jotka ovat oleellisia rakennusten lämmitys- ja jäähdytysenergian tarpeen sekä rakennuksen kokeman kosteusrasituksen kannalta. Työ keskittyy sää- ja ilmastotietoihin käsittelemättä rakennusten energiantarpeen tai rakenteiden toiminnan mallinnusta.

Suomen ilmastossa rakennusten lämmitys- ja jäähdytysenergian tarpeeseen vaikuttavista sääsuureista tärkeimmät ovat ulkoilman lämpötila ja kesällä auringon säteily. Niihin verrattuna tuulen nopeuden ja ilman kosteuden merkitykset ovat pienehköjä (Jylhä ym., 2011; Kalamees ym., 2012). Näiden neljän suureen ohella myös sateisuus vaikuttaa sellaisten sääolojen esiintymiseen ja kestoon, jotka voivat lisätä homeen kasvua ja kosteuden tiivistymistä rakenteisiin sekä hidastaa rakenteiden kuivumista (Vinha ym., 2013).

Rakennusten lämmitys- ja jäähdytysenergiankulutuksen tarkasteluja varten Suomi on jaettu neljään säävyöhykkeeseen (YMa 1010/2017: Liite 1). Vuonna 2011 kehitetty energialaskennan ilmastollinen testivuosi TRY2012 perustui säävyöhykkeillä I ja II Vantaan, vyöhykkeellä III Jyväskylän ja vyöhykkeellä IV Sodankylän säähavaintoihin vuosina 1980-2009 (taulukko 1.1; Jylhä ym., 2011). Useimpia sääsuureita koskevat havainnot oli tehty kolmen tunnin välien, ja ajan suhteen interpoloiden muodostettiin niiden pohjalta koko 30-vuotisjakson kattavat tunnittaisten säätietojen aikasarjat. Kyseisten säätietojen (Ruosteenoja ym., 2013) avulla valittiin myös kaksi rakennusfysiikan ilmastollista testivuotta (Jokioinen 2004 ja Vantaa 2007), jolloin sääolot olivat kosteusvaurioiden syntyä ajatellen tavallista hankalampia (Vinha ym., 2013). Sekä energialaskentaa että rakennusfysikaalisia tarkasteluja varten muodostettiin tuolloin myös tulevaisuuteen ulottuvat testivuodet säätietoineen kuvaamaan vuosien 2030, 2050 ja 2100 vaiheilla vallitsevaa ilmastoa; nämä perustuivat skenaarioon, jonka toteutuessa kasvihuonekaasujen päästöt jatkaisivat kasvuaan koko kuluvan vuosisadan.

Taulukko 1.1. Rakennetun ympäristön säätietoja koottaessa käytetyt säähavaintoasemat asemanumeroineen. Vyöhykkeet I-IV viittaavat rakennusten energialaskennan aluejakoon Suomessa (YMa 1010/2017: Liite 1). Pitkäaikaiset keskilämpötilat on ilmoitettu ilmastollisille vertailujaksoille 1971-2000 ja 1981-2010 sekä tässä työssä tarkastellulle jaksolle 1989-2018. Kahdessa viimeisessä sarakkeessa on annettu energialaskennan testivuosien TRY2012 ja TRY2020 keskilämpötilat.

\begin{tabular}{llrrrrrr}
\hline \multicolumn{1}{c}{ Havaintoasema } & $\begin{array}{l}\text { Aseman } \\
\text { numero } \\
\text { (FMISID) }\end{array}$ & Vyöhyke & \multicolumn{7}{c}{ Keskilämpötila $\left({ }^{\circ} \mathrm{C}\right)$} \\
& & & $1971-$ & $1981-$ & $1989-$ & TRY & TRY \\
& & & 2000 & 2010 & 2018 & 2012 & 2020 \\
\hline Vantaa, lentoasema & 100968 & I & 4,9 & 5,3 & 5,8 & 5,6 & 5,8 \\
Jokioinen, IImala & 101104 & II & 4,3 & 4,6 & 5,1 & - & 5,0 \\
Jyväskylä, lentoasema & 101339 & III & 2,9 & 3,3 & 3,8 & 3,4 & 3,6 \\
Sodankylä, Tähtelä & 101932 & IV & $-0,8$ & $-0,4$ & 0,3 & 0,1 & 0,4 \\
\hline
\end{tabular}


Kuten esimerkiksi taulukon 1.1 pitkäaikaiset tilastot osoittavat, ilmasto on yleisesti lämmennyt viimeisten vuosikymmenien aikana. Tämä herättää kysymyksen siitä, kuinka hyvin aiemmin laadittu testivuosi TR2012 kuvaa tuoreimman 30-vuotisjakson ilmastoa. Tämän tutkimuksen tavoitteena on tuottaa uusia, ajanmukaisia säätietoja sen arviointiin, miten ilmastonmuutos vaikuttaa rakennetun ympäristön sääolosuhteisiin. Keskimääräisten sääolojen lisäksi tarkastellaan rakennetun ympäristön kannalta merkityksellisiä sään ääri-ilmiöitä. Tarkasteluja varten on koottu 30 vuoden säähavainnot energialaskennan neljää säävyöhykettä edustavilta paikkakunnilta (Vantaa, Jokioinen, Jyväskylä ja Sodankylä) ajanjaksolta 1989-2018 ja muodostettu niistä tunnittaiset säätietojen aikasarjat. Näiden perusteella on valittu kullekin säävyöhykkeelle uusi rakennusten energialaskennan ilmastollinen testivuosi TRY2020 tunnittaisine säätietoineen. Toisaalta koska tähän työhön ei sisälly rakennusten kosteusteknisen toiminnan mallinnusta, ei myöskään ole laadittu uusia rakennusfysikaalisia testivuosia. Säähavaintojen laaja automatisointi noin kymmenen vuotta sitten tekee kuitenkin mahdolliseksi muodostaa tosiasiallisesti tunnin välein mitattujen säätietojen aikasarjoja. Rakennusfysikaalisia tarkasteluja varten on koottu tällainen vertailuvuosi, joka koostuu Jokioisten vuoden 2015 tunnittaisista säähavainnoista.

Säähavaintoihin perustuvien sääaineistojen lisäksi työssä on muodostettu 30-vuotiset säätietojen aikasarjat jaksoille 2015-2046 (lähitulevaisuutta kuvaava ilmasto), 2035-2064 (kuluvan vuosisadan puoliväliä kuvaava ilmasto) ja 2065-2094 (kuluvan vuosisadan loppupuolen ilmasto); kyseiset ilmastolliset jaksot on nimetty keskikohtiensa eli vuosien 2030, 2050 ja 2080 mukaan. Arviot perustuvat ilmastomallien tuloksiin, ja huomioon on otettu kolme vaihtoehtoista maailmanlaajuisten kasvihuonekaasujen pitoisuuksien skenaariota. Mainituille tulevaisuuden jaksoille on laadittu rakennusten energialaskennan tulevaisuuden testivuosiaineistot. Samoin on arvioitu, millaisia olisivat rakennusfysikaalisten tarkastelujen vertailuvuotta vastaavat sääolot tulevaisuuden muuttuneessa ilmastossa.

Kuvien 1.1-1.2 lohkokaaviot valottavat tässä työssä tuotettujen aineistojen laadintaa verrattuna siihen, miten rakennusten energialaskennan testivuosi TRY2012 ja rakennusfysiikan ilmastolliset testivuodet (Jokioinen 2004 ja Vantaa 2007) on aikanaan muodostettu. Paitsi että tässä raportissa käytetään työn pohjana aiempaa tuoreempaa 30-vuotisjaksoa, myös hyödynnetyt ilmastomallien tulokset ovat uudempia. Menetelmät ovat pääpiirteiltään samoja kuin mitä Jylhä ym. (2011) ja Ruosteenoja ym. (2013) käyttivät, mutta joissakin yksityiskohdissa menetelmiä on pyritty kehittämään.

Samoin kuin aiempien ilmastollisten testivuosien säätiedot, myös tässä raportissa kuvattavat uudet ajantasaiset säätiedot ovat ladattavissa Ilmatieteen laitoksen verkkosivuilta. Työn tuloksia voidaan hyödyntää pyrittäessä parantamaan rakennetun ympäristön toimijoiden ja toimialojen varautumista tulevaan ilmastonmuutokseen. Lisäksi tämän raportin tutkimustulosten on tarkoitus herättää keskustelua rakentamiseen ja rakennuksiin liittyvistä näkemyksistä ja kehitysideoista, esimerkiksi siitä, kuinka rakennuksen kokeman kosteuskuormituksen lisääntymiseen ja sisäolosuhteiden kuormittavuuteen voitaisiin tulevaisuuden ilmastossa varautua ja miten näiden asioiden tulisi näkyä rakentamisen ohjeistamisessa.

Tämän raportin luvut 1-6 koostavat lyhyesti tehdyn työn ja keskeiset tulokset. Liitteissä 1-6 esitetään yksityiskohtaisemmat kuvaukset työn eri vaiheista. 


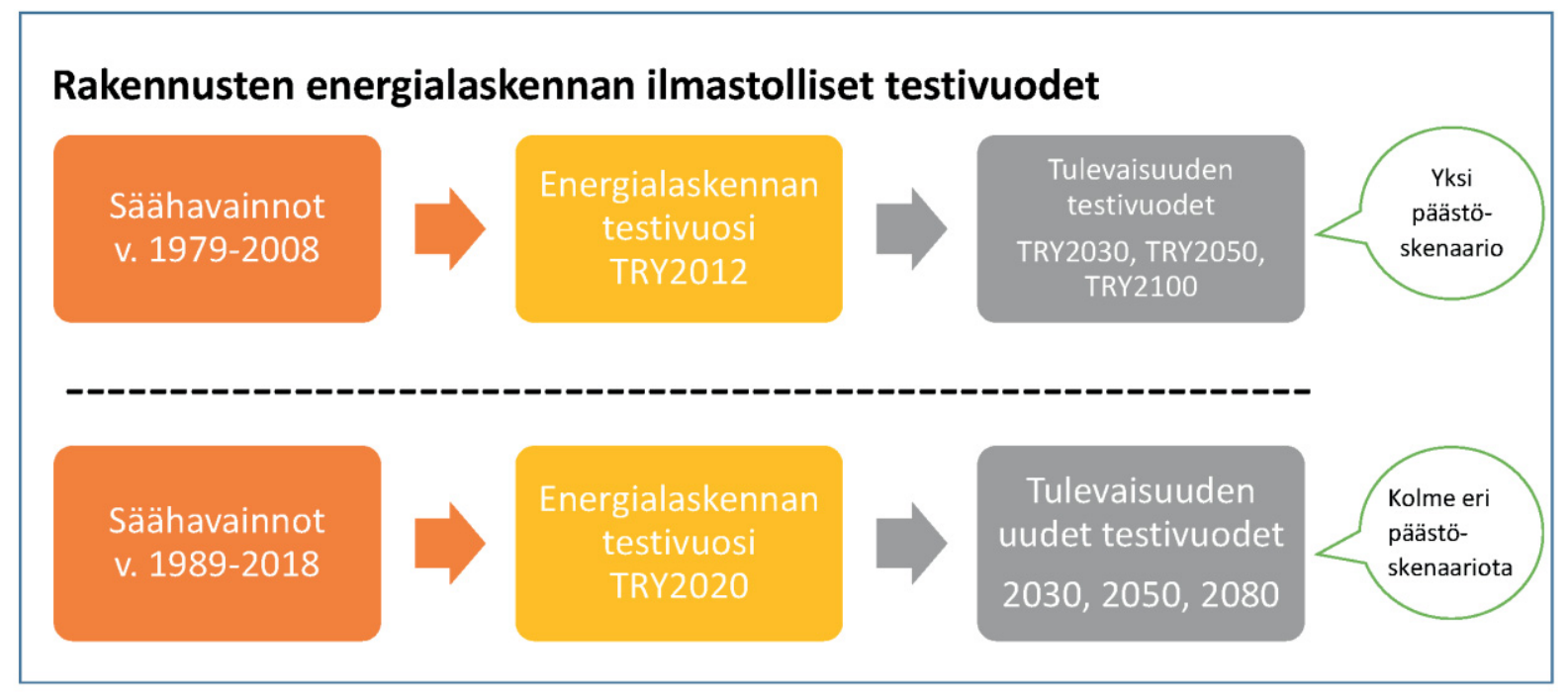

Kuva 1.1: Kaaviokuva aiemmin laaditun energialaskennan ilmastollisen testivuosiaineiston TRY2012 (ylärivi) ja tässä työssä muodostetun TRY2020-aineiston (alarivi) tuottamisesta.

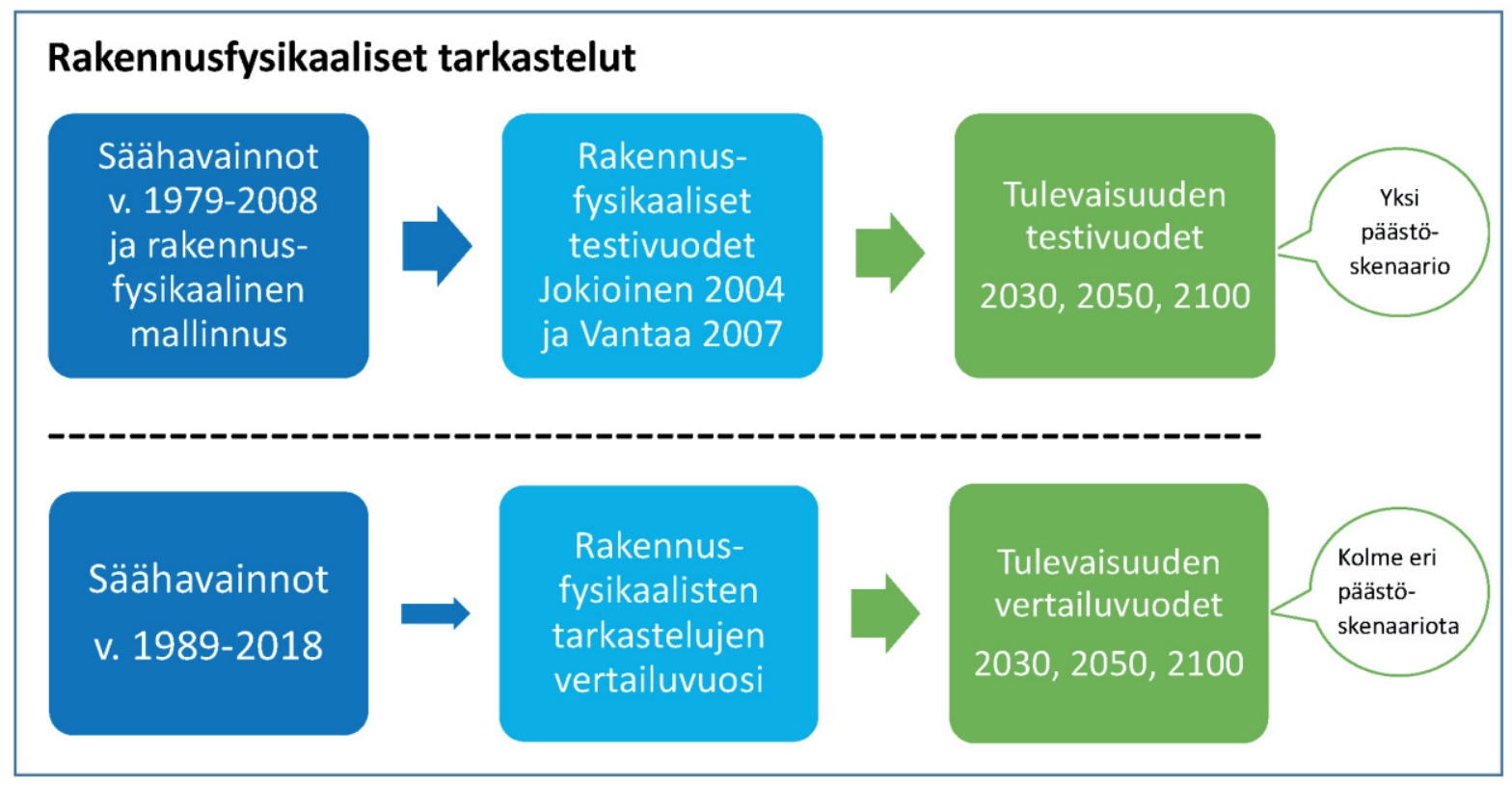

Kuva 1.2: Kaaviokuva rakennusfysiikan ilmastollisten testivuosiaineistojen (ylärivi) ja tässä työssä laaditun rakennusfysikaalisten tarkastelujen vertailuvuosiaineiston (alarivi) tuottamisesta.

Tämän hankkeen eräs osatehtävä oli selvittää vastaavan tutkimusaiheen viimeaikaisia tuloksia naapurimaissa (etenkin Ruotsi, Norja, Tanska). Tähän liittyen voidaan lyhyesti todeta, ettei naapurimaissa eikä itse asiassa liiemmin koko Euroopassakaan ole viime vuosina julkaistu päivitettyjä rakennusenergian testivuosien aineistoja; tuoreimmat vertaisarvioidut julkaisut löytyvät Suomesta (Kalamees ym. 2012; Jylhä ym., 2015a, 2015b). On myös mahdollista, että jokin maa on julkaissut omalla kielellään sisäisiä raportteja tai selvityksiä, joita ei tavanomisin 
kirjallisuushakumenetelmin löydy. Huomattakoon, että asiasta konsultoitiin Ilmatieteen laitoksen pohjoismaisia sisarlaitoksia sekä Euroopan ilmastopalveluiden EUMETNET-konsortiota.

Sen sijaan ilmastonmuutoksen vaikutuksia rakennetussa ympäristössä, rakennetun ympäristön sopeutumista muuttuviin olosuhteisiin, hulevesien hallintaa yms. on käsitelty useissa eurooppalaisissa tutkimushankkeissa. Esimerkiksi Norjassa on meneillään laajahko Klima $2050^{14}$-tutkimusohjelma, jossa on mukana tutkimuslaitosten ohella sekä yksityisen että julkisen sektorin toimijoita. Ko. ohjelman julkaisuluettelossa on laaja joukko julkaisuja; nämä eivät kuitenkaan käsittele säätietojen tuottamista.

\subsection{Ilmastonmuutos}

Meneillään oleva ilmastonmuutos vaikuttaa sekä tyypillisiin, harvinaisiin että poikkeuksellisiin sääoloihin. Meteorologinen tilanne voi olla äärevä sekä tasoltaan, siis poikkeamana keskiarvosta, että kestoltaan. Äärevät olosuhteet ovat merkittäviä rakennusten kosteusrasituksen kannalta; erityisesti vaikuttavat lämpötila, suhteellinen kosteus ja sade sekä varsinkin viistosateen esiintyminen ja kesto. Energiankulutusta tarkasteltaessa tärkeitä ovat lämpötila, auringon säteily, tuulisuus ja suhteellinen kosteus.

Suomessa ilmasto on lämmennyt noin kaksi astetta 1900-luvun alusta nykypäivään (kuva 1.3), ja lämpeneminen on kiihtynyt viime vuosikymmeninä.

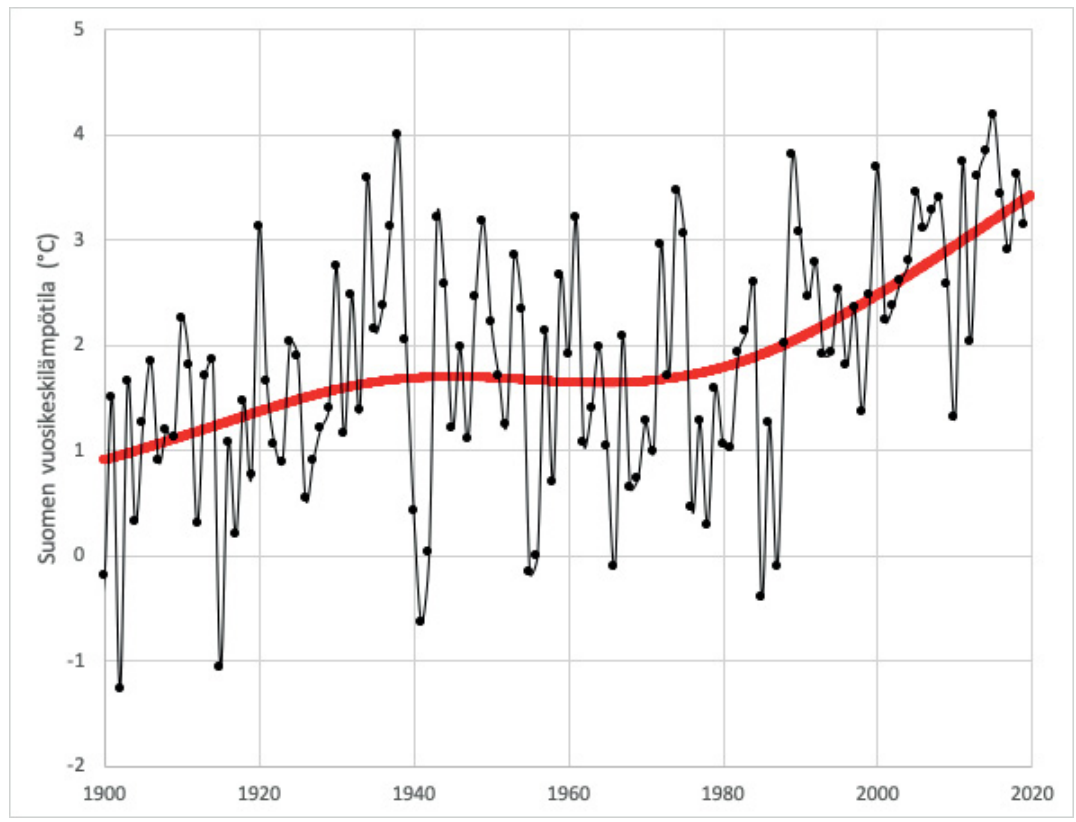

Kuva 1.3: Suomen vuosikeskilämpötila 1900-2019. Mustilla pisteillä merkityt vuosittaiset arvot perustuvat koko Suomen kattavaan hila-aineistoon. Punainen viiva osoittaa tilastollisen mallin mukaista keskimääräisen vuosikeskilämpötilan kulkua. Muokattu alkuperäisestä Mikkosen ym. (2015) esittämästä aikasarjasta.

\footnotetext{
14 http://www.klima2050.no/
} 
Vuodenajoista eniten on lämmennyt talvi (lämpeneminen $2-3{ }^{\circ} \mathrm{C}$ ) ja vähiten kesä (noin $1{ }^{\circ} \mathrm{C}$ ). Kuten kuvasta 1.3 selvästi nähdään, keskilämpötilan vaihtelu vuodesta toiseen on suurta; huomattakoon, että vaihtelua on odotettavissa myös tulevaisuudessa. Toinen selvä havainto kuvasta 1.3 on erityisen voimakas lämpeneminen viime vuosikymmeninä.

Nykyisin käytössä olevat ilmastomallitulokset pohjautuvat ns. CMIP5-malleihin ja RCPkasvihuonekaasuskenaarioihin, joita hallitustenvälinen ilmastonmuutospaneeli IPCC käyttää arvioissaan. kolmen eri skenaarion mukaan Kuvassa 1.4 on esitetty ihmiskunnan ilmakehään vuosittain päästämän hiilidioksidin $\left(\mathrm{CO}_{2}\right)$ määrä ja sen havaittu pitoisuus vuodesta 1950 lähtien sekä päästöjen ja ilmakehän hiilidioksidipitoisuuden ennustettu kehitys vuoteen 2100 asti kolmen eri skenaarion mukaan. Skenaariojakson ensimmäisen vuosikymmenen kuluessa toteutuneet päästöt ja pitoisuudet (mustat katkoviivat) ovat seuranneet suurten päästöjen skenaariota.

Ilmatieteen laitos on tuottanut Suomea koskevia ilmastonmuutosarvioita näiden samojen CMIP5-mallien tuloksia käyttäen (Ruosteenoja ym. 2016) sekä tehnyt ja ollut mukana tekemässä näiden pohjalta räätälöityjä tilaustutkimuksia sekä julkiselle että yksityiselle sektorille (mm. pääkaupunkiseutu [Mäkelä ym., 2016, Pilli-Sihvola ym., 2018], Kemijoki Oy [Veijalainen ym., 2018], UPM-Kymmene Oyj [Venäläinen ym., 2019], Caruna Oy [Lehtonen ym., 2019a] ja Tapio Oy [Lehtonen ym., 2020]).
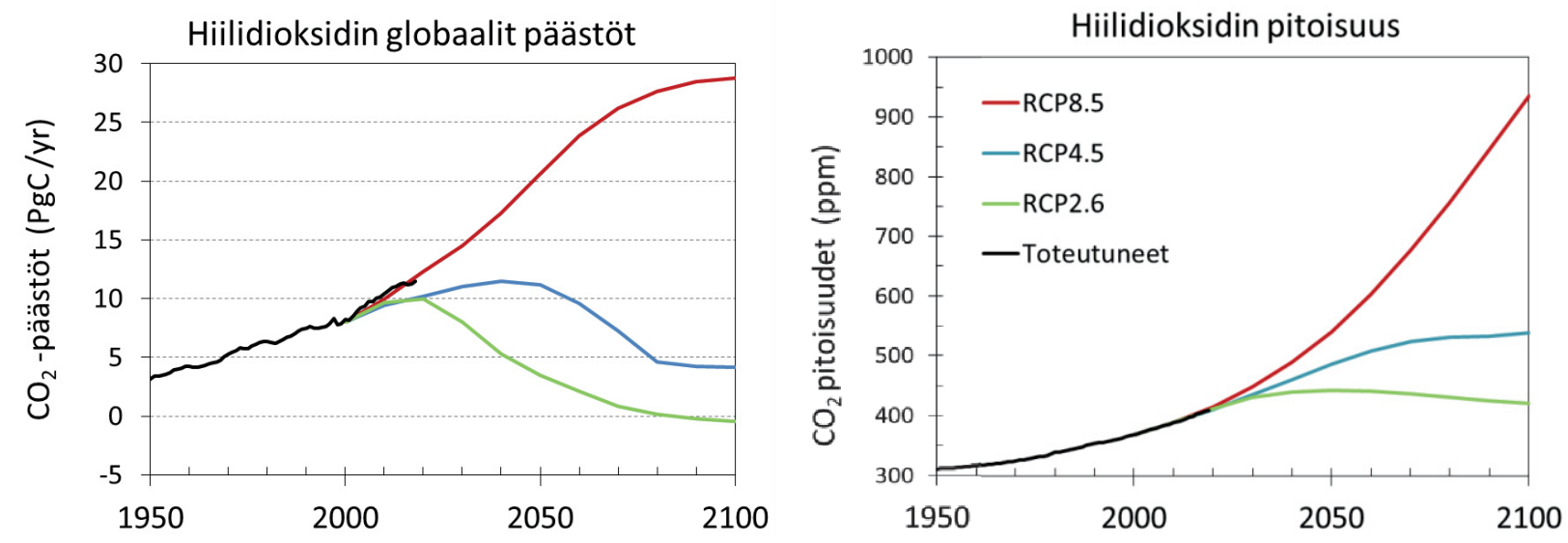

Kuva 1.4: Hiilidioksidin ( $\mathrm{CO}_{2}$ ) maailmanlaajuiset päästöt (vasen) sekä pitoisuus ilmakehässä (oikea) kolmen RCP-skenaarion mukaan. Musta käyrä esittää toteutuneita päästöjä (vasen) ja havaittuja pitoisuuksia (oikea). Lähteet: IPCC (2013) liitteen II taulukot AII.2.1c ja AII.4.1; Global Carbon Project (2019); NOAA ESRL DATA (6.10.2020).

Suomessa ja muualla Pohjois-Euroopassa ilmasto on muuttunut ja muuttuu eri tavoin kuin Keski- ja Etelä-Euroopassa. Tämä nähdään kuvasta 1.5, joka esittää Vantaan sekä muutamien muiden eurooppalaisten kaupunkien ilmastonmuutosarvioita. Etelä-Euroopassa kesien voimakas lämpeneminen sekä sademäärien väheneminen (ja siihen liittyvä kuivuus) aiheuttavat hyvin erilaisia haasteita kuin mitä Suomessa talvisten sateiden runsastuminen ja talvien leudontuminen. 

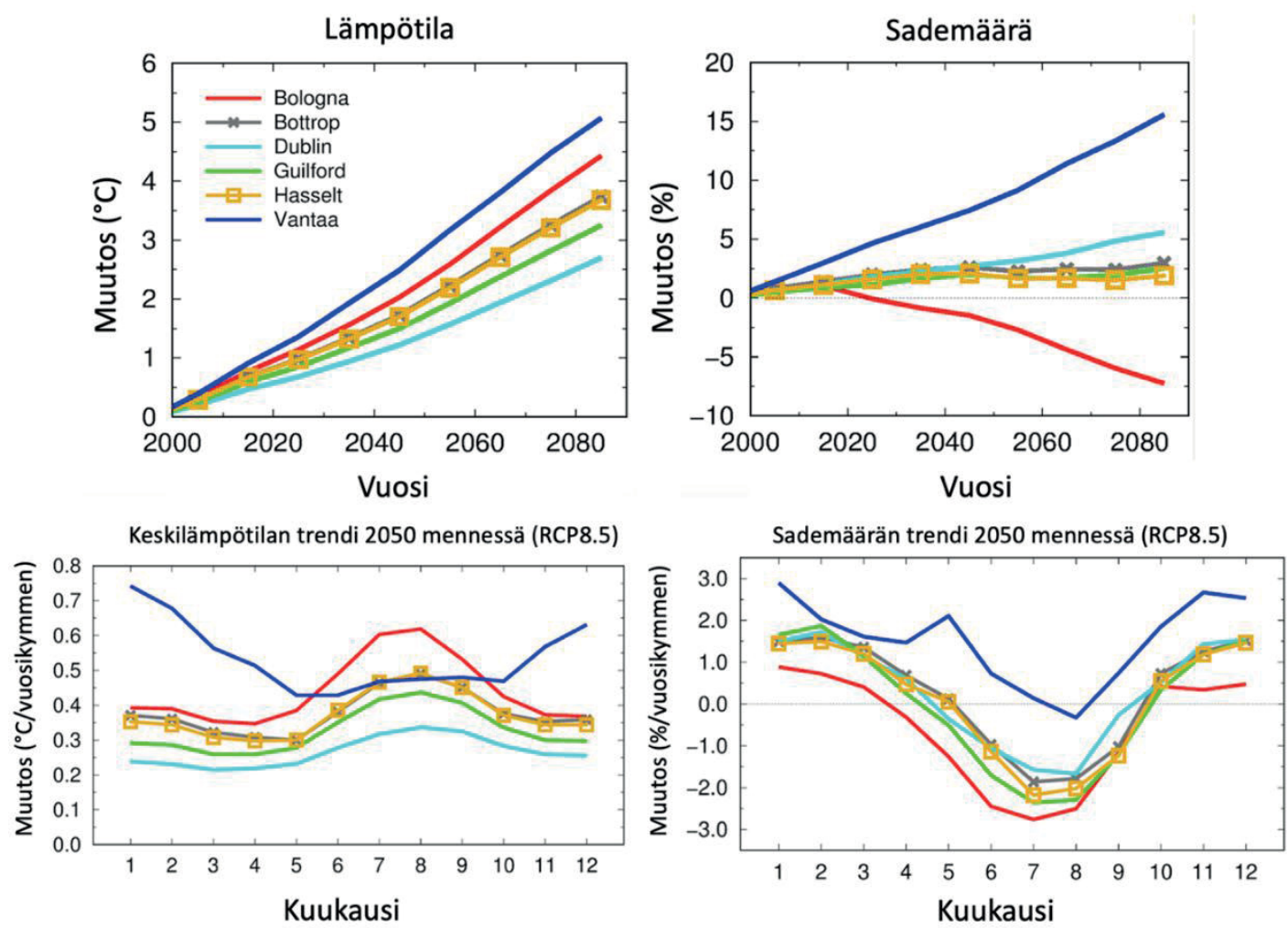

Kuva 1.5: RCP8.5-päästöskenaarion mukaan arvioidut keskilämpötilan ja sademäärän muutokset Bolognassa (Italia), Bottropissa (Saksa), Dublinissa (Irlanti), Guilfordissa (Englanti), Hasseltissa (Belgia) sekä Vantaalla. Muokattu Jylhän ym. (2019) esittämien kuvien pohjalta.

\section{Nykyistä ilmastoa kuvaavat säätiedot}

\subsection{0-vuotiset tunnittaiset aikasarjat}

Ilmatieteen laitoksen tekemistä säähavainnoista Vantaalla, Jokioisissa, Jyväskylässä ja Sodankylässä jakson 1989-2018 aikana muodostettiin 30-vuotiset tunnittaiset aikasarjat seuraaville suureille:

- lämpötila (TEMP $\left.\left[{ }^{\circ} \mathrm{C}\right]\right)$,

- suhteellinen kosteus (RH [\%]),

- tuulen nopeus (WS [m/s]),

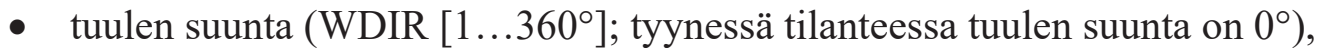

- auringon kokonaissäteily vaakapinnalle (GHI $\left.\left[\mathrm{W} / \mathrm{m}^{2}\right]\right)$,

- auringon hajasäteilyn teho vaakapinnalle (DHI $\left.\left[\mathrm{W} / \mathrm{m}^{2}\right]\right)$,

- suora auringonsäteily sädettä vastaan kohtisuoralle pinnalle (DNI [W/m²]), ja

- sademäärä (PRECIP $[\mathrm{mm} / \mathrm{h}])$.

Ilmatieteen laitoksen manuaaliset ja automaattiset säähavainnot käyvät läpi päivittäiset laatuja virhetarkastukset. Automaattiasemilta saatavien havaintoarvojen laatu tarkistetaan automaattisten testien avulla. Automaattisen laaduntarkastuksen ilmoittamat epäilyttävät tai virheelliset arvot tutkitaan vielä manuaalisesti havaintojen laadun varmistamiseksi. Lisäksi hankkeessa 
tuotetut 30-vuotiset aikasarjat tarkistettiin lopulta mahdollisten aukkojen löytämiseksi, ja puuttuvat säähavainnot täydennettiin mahdollisimman luotettavaksi katsotulla tavalla.

Tavoitteena oli, että laadittavat 30-vuotiset sääaikasarjat olisivat mahdollisimman homogeenisia huolimatta manuaalisten havaintojen vähenemisestä ja automaattisten havaintojen lisääntymisestä jakson 1989-2018 aikana. Tämän vuoksi lämpötilan, suhteellisen kosteuden ja tuulen tunnittaiset arvot on muodostettu kolmen tunnin välein tehtyjen ns. synoptisten havaintojen avulla ja tunnittaiset sademäärät on arvioitu 12 tunnin sademäärien ja sääilmiöitä koskevien tietojen perusteella, vaikka viimeiseltä kymmeneltä vuodelta niille olisi ollut käytettävissä myös automaattisin havaintolaittein tehtyjä tunnittaisia mittauksia. Auringon kokonais- ja hajasäteilyä on sen sijaan mitattu koko ajan jatkuvatoimisesti.

Seuraavassa kuvataan lyhyesti eri sääsuureiden aineistojen tuottamisessa käytettyjä menetelmiä.

\section{Lämpötila, suhteellinen kosteus ja tuuli}

Lämpötilat interpoloitiin lineaarisesti edellisen ja seuraavan synoptisen havaintoajan mittauksista. Lisäksi otettiin huomioon kyseisen vuorokauden mitatut minimi- ja maksimilämpötilat. Kunkin 24 tunnin jakson (alkaen edellisenä vuorokautena klo 20 ja päättyen kyseisenä vuorokautena klo 20 talviajassa) alimmat ja ylimmät interpoloidut (ei havaitut) arvot korvattiin kyseisen vuorokauden mitatuilla minimi- ja maksimilämpötiloilla. Näin tehtiin, mikäli nämä minimi- ja maksimilämpötilat olivat äärevämpiä kuin synop-havaintojen lämpötilamittaukset, kuten ne yleensä olivat. Korvaamisen jälkeen myös viereiseen interpoloituun arvoon tehtiin hienosäätöä interpoloimalla se uudelleen.

Suhteelliset kosteudet ja tuulen nopeudet interpoloitiin suoraan edellisen ja seuraavan synophavaintoajan mittauksista. Tuulen suunnat interpoloitiin puolestaan edellisen ja seuraavan synop-havaintoajan itä-länsi- ja pohjois-etelä - suuntaisten tuulikomponenttien avulla. Jos oli kuitenkin ollut tyyntä jompanakumpana havaintoajoista, tuulen suunta pidettiin samana kuin tuulisena havaintoaikana.

Kuvassa 2.1 on esitetty aikasarjojen laatimisen tuloksina saadut vuotuiset frekvenssijakaumat Vantaalla ja Sodankylässä. Vastaavat talvi- ja kesäaikaiset frekvenssijakaumat Jyväskylälle nähdään myöhemmin kuvista 3.2-3.3.

Auringon säteily

Säteilyaikasarjaa muodostettaessa otettiin mukaan seuraavat auringonsäteilyn komponentit: kokonaissäteily (GHI), hajasäteily (DHI) ja sädettä vastaan kohtisuoralle pinnalle tuleva suora säteily (DNI). Havaintoaineistona käytettiin kokonais- ja hajasäteilystä koostuvia tuntiaikasarjoja. Suoran säteilyn havaintoja ei hyödynnetty, vaan se arvioitiin kokonaissäteilyn ja hajasäteilyn pohjalta. Kuvassa 2.2 on esimerkki tuloksista lasketuista kuukausikeskiarvoista. Myös pää- ja väli-ilmansuuntiin suunnatuille 45 ja 90 asteen kallistuskulman tasoille osuva kokonaissäteily määritettiin. Koostetut mittausaikasarjat ajettiin erinäisten laatutarkastusten läpi, joista on annettu tarkempaa tietoa sekä esimerkkikuvia liitteessä 1 . 

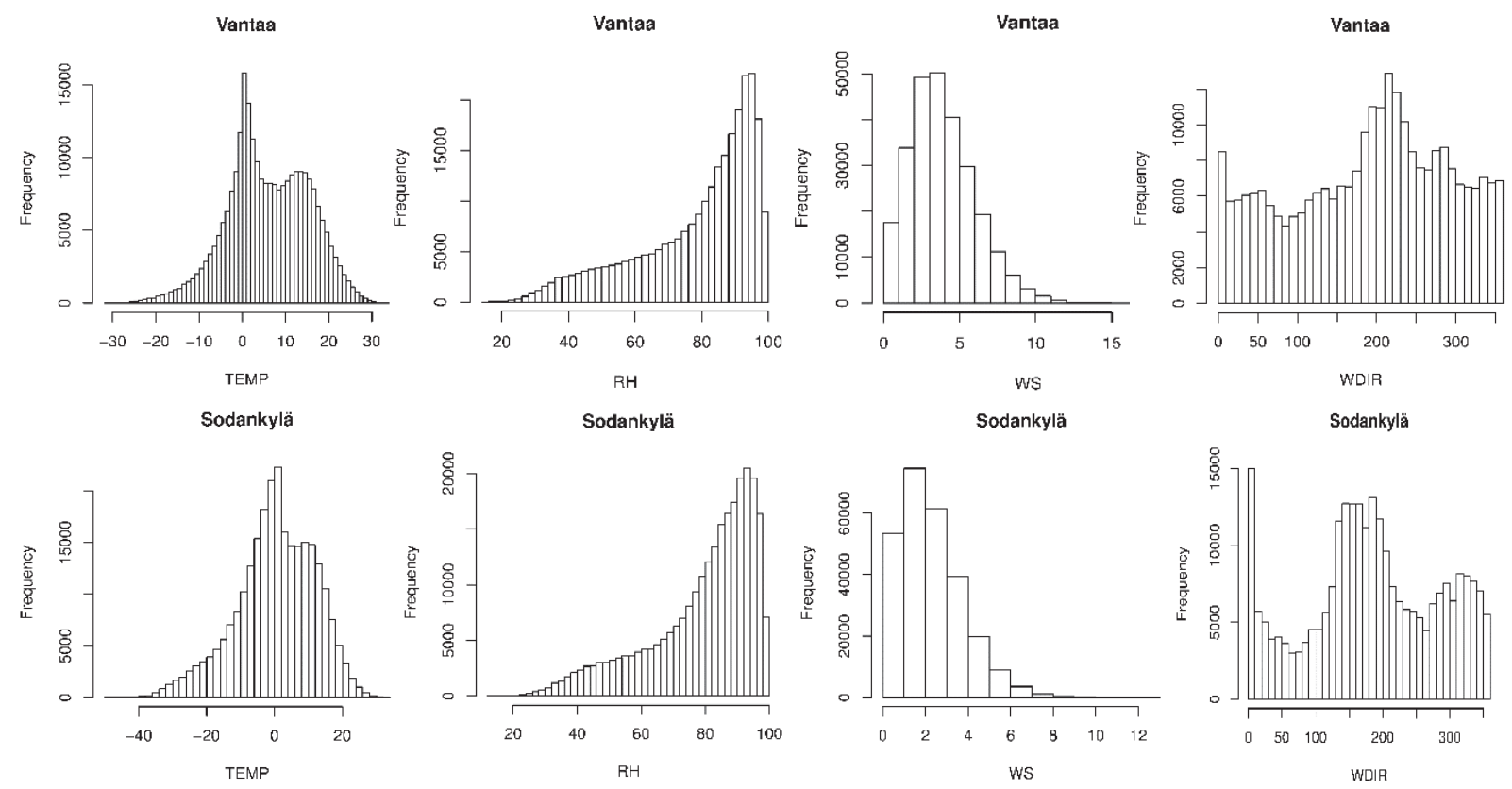

Kuva 2.1: Lämpötilan (TEMP; $\left.{ }^{\circ} \mathrm{C}\right)$, suhteellisten kosteuden (RH; \%), tuulen nopeuden (WS, $\mathrm{m} / \mathrm{s}$ ) ja tuulen suunnan (WDIR, ${ }^{\circ}$ ) tunnittaisten arvojen frekvenssijakaumat v. 1989-2018 Vantaalla (vyöhyke I) ja Sodankylässä (vyöhyke IV). Huomaa asteikkojen erot.

\section{Jyväskylä 1989-2018}

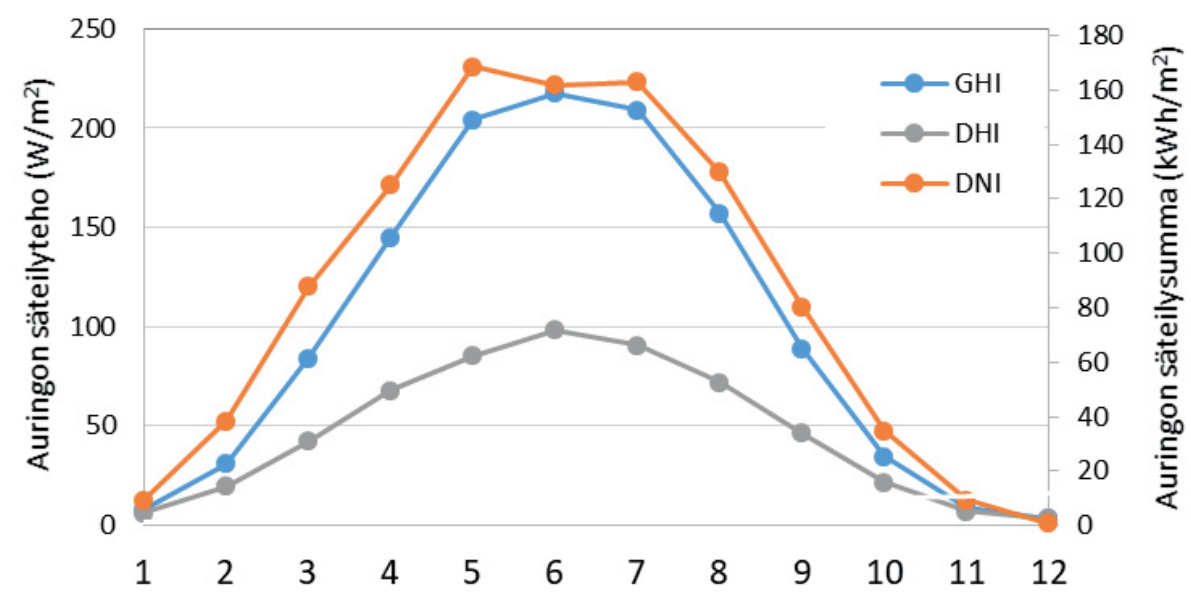

Kuva 2.2: Auringon kokonaissäteily vaakapinnalle (GHI), hajasäteily vaakapinnalle (DHI) ja suora säteily sädettä vastaan kohtisuoralle pinnalle (DNI) kalenterikuukausittain Jyväskylässä vuosien 1989-2018 mittausten perusteella koko kuukauden keskimääräisenä tehona (vasen akseli, yksikkö $\mathrm{W} / \mathrm{m}^{2}$ ) ja säteilysummana (oikea akseli, yksikkö $\mathrm{kWh} / \mathrm{m}^{2}$ ). Koko vuoden arvot ovat $99 \mathrm{~W} / \mathrm{m}^{2}$ ja $874 \mathrm{kWh} / \mathrm{m}^{2}$ (GHI), $47 \mathrm{~W} / \mathrm{m}^{2}$ ja $411 \mathrm{kWh} / \mathrm{m}^{2}$ (DHI) sekä $115 \mathrm{~W} / \mathrm{m}^{2}$ ja 1013 $k W h / m^{2}(D N I)$. 


\section{Sademäärä}

Työssä tuotettiin sademäärät valituille paikkakunnille tunnin välein, mutta suurelta osalta tarkasteltavaa ajanjaksoa (v. 1989-2018) sademääriä oli mitattu ainoastaan 12 tunnin välein. Tämä tarkoittaa sitä, että 12 tunnin aikana kertyneet sademäärät tuli jakaa yksittäisille tunneille jollakin tavoin. Tässä työssä käytetty menetelmä perustuu aiemmin Ruosteenojan ym. (2013) kuvaamaan toimintatapaan, jossa mitatut 12 tunnin sademäärät jaettiin tasaisesti niille tunneille, joita ei voitu osoittaa poutaisiksi. Aiemmin kuitenkin tyydyttiin tunnistamaan kolmen tunnin poutaiset jaksot, kun taas nyt pyrittiin tunnin tarkkuuteen.

Vuoteen 2009 asti oli käytettävissä havainnontekijän manuaalisesti kirjaamia tietoja sääilmiöistä, minkä jälkeen sateen esiintymistä koskevat tiedot perustuivat automaattisiin vallitsevan sään mittauksiin. Havaintojen automatisointi kesken tarkastelujakson johti siihen, että tarkastelujakson alku- ja loppupuolella jouduttiin käyttämään kahta keskenään hieman erilaista tuntisateiden arviointimenetelmää. Menetelmiä oli mahdollista vertailla vuoden 2009 havaintojen avulla, koska tuolta vuodelta oli käytettävissä sekä manuaaliset että automaattiset havainnot sääilmiöistä. Vertailun (liitteen 2 taulukko L2.1) perusteella voidaan sanoa, etteivät laadittujen tuntisateiden aikasarjojen poudan ja sateen yleisyyttä ja sateiden voimakkuutta koskevat tilastolliset ominaisuudet muuttuneet oleellisesti, kun käytettävää arviointimenetelmää muutettiin vuoden 2009 kohdalla.

Muodostettujen tunnittaisten sadetietojen laatua arvioitiin vertaamalla niitä Jokioisissa vuonna 2015 tehtyihin suoriin automaattisiin tuntisademäärien mittauksiin (katso myös lukua 2.4). Poutaisten tai lähes sateettomien tuntien (sademäärä alle $0.1 \mathrm{~mm} / \mathrm{h}$ ) osuus kaikista vuoden 2015 tunneista oli arviointimenetelmän perusteella $83 \%$, mikä on käytännössä sama kuin poudan osuus sademittauksissa (taulukko L2.2). Sademittaukset ja arviointimenetelmä olivat yhtä mieltä poudan tai sateen sattumisesta 90 prosentissa tapauksista. Tarkasteltaessa vain tunteja, jolloin automaattinen sademittari oli havainnut sadetta edes hieman $(>0 \mathrm{~mm} / \mathrm{h})$, saatiin mittausten ja arvioiden väliseksi tilastollisesti merkitseväksi korrelaatioksi $0.64\left(p<10^{-4}\right)$. Lisävertailujen perusteella voitiin todelta, että vaikka arviointimenetelmä kuvaa varsin hyvin tuntisateiden tilastollisia ominaisuuksia v. 2015, se hieman yliarvioi sateisten tuntien sademäärän mediaania ja aliarvioi keskiarvoa. Sitä paitsi yksittäistapauksissa arviot ja suorat tuntimittaukset voivat poiketa toisistaan paljonkin.

Kuva 2.3 esittää tunnittaisten sademäärien käänteiset summafrekvenssijakaumat koko jakson 1989-2018 ajalta. Tulosten mukaan noin 90 prosentissa tunneista sataa enintään $0.2 \mathrm{~mm} / \mathrm{h}$. Keskimäärin joka sadas tunti sademäärä oli Sodankylässä vähintään $1.0 \mathrm{~mm} / \mathrm{h}$, ja Vantaalla 1.4 $\mathrm{mm} / \mathrm{h}$ ja muilla paikkakunnilla näiden arvojen välillä. Sodankylän pienemmät tuntisademäärät verrattuna eteläisempiin sääasemiin on ilmastojen erot huomioon ottaen odotettavissa oleva tulos, mutta jossain määrin eroihin on voinut vaikuttaa myös se, että vallitsevan sään mittauksia puuttui siellä huomattavasti enemmän kuin muualla (liite 2). Niinpä tietoa poutatunneista jäi saamatta.

Laaditun aineiston mukaan suurimmat tunnin aikana tulleet sademäärät olivat havaintoasemasta riippuen 5.4-16.6 mm/h (kuva 2.3). Vantaalla, Jyväskylässä ja Sodankylässä koko 12 tunnin sademäärä pystyttiin noissa tilanteissa kohdentamaan yhdelle tunnille, kun taas Jokioisissa mitattu 12 tunnin sademäärä, $33.2 \mathrm{~mm} / 12 \mathrm{~h}$, jaettiin käytetyn menetelmän mukaisesti tasan kahdelle tunnille. Säätutkakuvien perusteella suurimmat tuntisateet ovat aiheutuneet joko 
pienialaisista sadekuurojonoista tai laajempaan sadealueeseen kuuluneesta kapeasta hyvin konvektiivisesta vyöhykkeestä (liitteen 2 kuva L2.4).

Sadeaineiston laatiminen ja sitä koskevat vertailut tuloksineen on kuvattu seikkaperäisesti liitteessä 2. Mainittakoon, että tutkimuksen alkuvaiheessa suunnitelmana oli hyödyntää tunnittaisten sademäärien laskemiseen myös ns. ERA5-uusanalyysitietoja. Tätä alustavaa suunnitelmaa varten tehdyt selvitykset on myös esitetty liitteessä 2 .

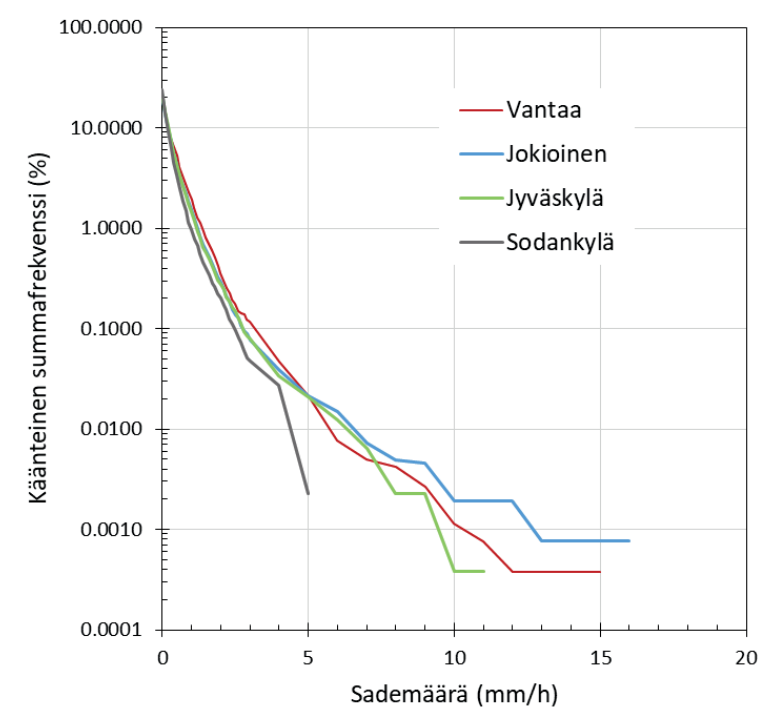

Kuva 2.3: Tunnittaisten sademäärien $(\mathrm{mm} / \mathrm{h})$ käänteiset summafrekvenssijakaumat (\%) Vantaalla, Jokioisissa, Jyväskylässä ja Sodankylässä vuosia 1989-2018 koskevien arvioiden perusteella. Kunkin paikkakunnan jakaumat perustuvat 262968 arvoon.

\subsection{Rakennusten energialaskennan uudet testivuodet (TRY2020)}

Energialaskennan testivuosien valintaa varten tarvittiin neljän säämuuttujan (lämpötila, globaalisäteily, tuulen nopeus ja vesihöyryn osapaine) yhtenäiset aikasarjat 30 vuodelta vuorokautisten keskiarvojen laskemista varten. Aikasarjoja luotaessa jouduttiin täydentämään puuttuvia havaintoja. Esimerkiksi Jokioisten puuttuvia havaintoja on korvattu i) suhteellisen lähellä sijaitsevien Salon (Kärkkä) ja Kiikalan sääasemien havainnoilla, ii) edellisen ja seuraavan havainnon keskiarvoilla sekä iii) vuorokautista hila-aineistoa (FMIClimgrid; Aalto ym., 2016) hyödyntäen.

Energialaskennan uusiin testivuosiin TRY2020 mukaan otettujen kuukausien aikana sään tilastolliset jakaumat ovat muistuttaneet mahdollisimman paljon 30-vuotisjakson 1989-2018 keskimääräisiä jakaumia. Valintamenetelmä perustui muokattuun ISO-standardiin (SFS EN ISO 15927-4, 2005), ja sen pääpiirteet on esitetty aiemmissa julkaisuissa (Jylhä ym., 2011; Kalamees ym., 2012) sekä tämän raportin liitteessä 3. Testivuoden kunkin 12 tyyppikuukauden määrittämistä varten valittiin kolme ehdokasta vuorokautisten keskiarvojen summafrekvenssijakaumien (pysyvyyskäyrien) perusteella ns. Finkelstein-Schafer (FS) -parametrien avulla. Kunkin säämuuttujan, vuoden ja kuukauden summafrekvenssijakaumia verrattiin pitkäaikaisiin (30 vuoden) jakaumiin ja lisäksi huomioon otettiin se, kuinka merkittävä kyseinen säämuuttuja on rakennusten lämmitys- ja jäähdytystarpeen kannalta Suomessa eri vuodenaikoina. Tässä työssä lopulliseen valintaan kolmen ehdokkaan välillä vaikuttivat FS-parametrien painotetun 
summan lisäksi aritmeettiset kuukausikeskiarvot ja keskihajonnat sekä pyrkimys välttää liian suuria keinotekoisia säätilojen muutoksia kuukausien vaihteessa. Lisäksi kuukausia toisiinsa liitettäessä tarvittavien tasoitusten tekotapaa kehitettiin aiempaan verrattuna. Lopulliset valinnat koostuivat siten muutamasta iteratiivisesta vaiheesta, jotka on kuvattu tarkemmin liitteessä 3.

Uusien testivuosien koostuminen eri historiallisten vuosien kuukausista nähdään taulukosta 2.1. Energialaskennan säävyöhykkeillä I ja II lähes kaikkien kuukausien säätiedot ovat keskenään samoilta vuosilta, sijaitsevathan niitä edustavat säähavaintoasemat, Vantaa ja Jokioinen, melko lähellä toisiaan. Poikkeuksina olivat touko-, elo- ja lokakuu. Myös vyöhykkeellä III tammi-, syys-, marras- ja joulukuun säätiedot ovat peräisin samoilta vuosilta kuin kahdella eteläisemmällä vyöhykkeellä. Sen sijaan vyöhykettä IV edustavan Sodankylän vuodet poikkeavat muista kaikissa tapauksissa.

Taulukko 2.1: Uudet energialaskennan testivuodet vyöhykkeillä $I-I V(I=$ Vantaa, II = Jokioinen, III = Jyväskylä, IV = Sodankylä). Testivuodet on valittu vuosina 1989-2018 tehtyjen säähavaintojen perusteella säämuuttujien painotusta käyttäen. Esitettyinä ovat vuodet, joilta kunkin testivuoden kuukaudet (1-12) ovat peräisin.

\begin{tabular}{ccccccccccccc}
\hline Vyöhyke & 1 & 2 & 3 & 4 & 5 & 6 & 7 & 8 & 9 & 10 & 11 & 12 \\
\hline I & 2002 & 1998 & 2004 & 2012 & 2006 & 2005 & 1989 & 2003 & 1998 & 2012 & 2006 & 1998 \\
II & 2002 & 1998 & 2004 & 2012 & 2011 & 2005 & 1989 & 1994 & 1998 & 2004 & 2006 & 1998 \\
III & 2002 & 2003 & 1999 & 1991 & 2012 & 1996 & 2009 & 1990 & 1998 & 2014 & 2006 & 1998 \\
IV & 1998 & 1997 & 2009 & 1999 & 1993 & 2010 & 2013 & 2011 & 2012 & 2013 & 2017 & 2015 \\
\hline
\end{tabular}

Kuva 2.4 esittää lämpötilan tunnittaisten arvojen vuotuista kulkua vyöhykkeillä I ja IV esimerkkinä säämuuttujien aikasarjoista TRY2020:n aikana.

Vantaa

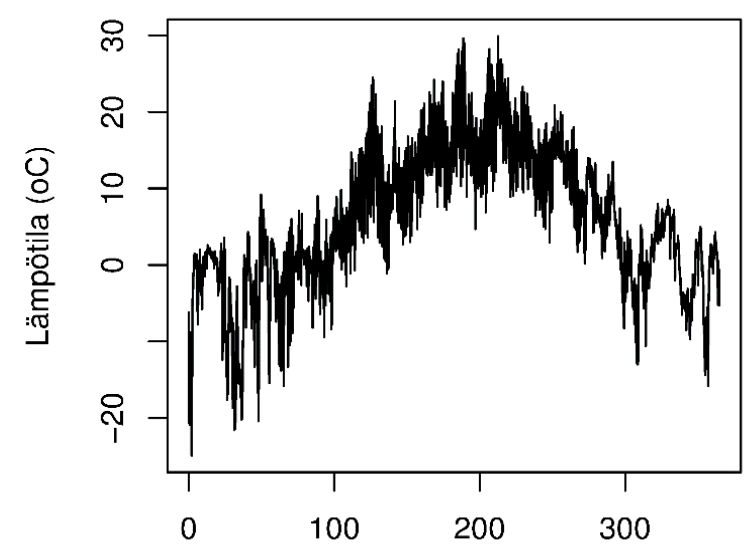

Testivuoden TRY2020 vuorokaudet
Sodankylä

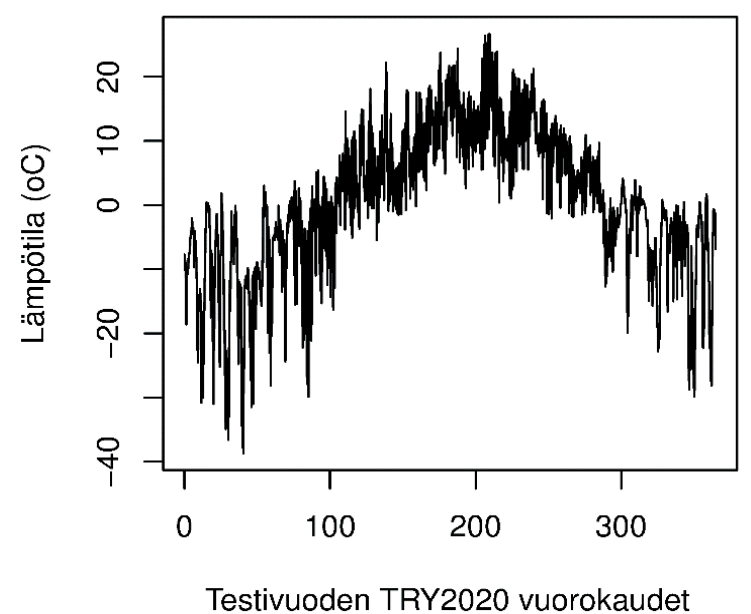

Kuva 2.4: Lämpötilan $\left({ }^{\circ} \mathrm{C}\right)$ vuotuinen kulku uuden testivuoden aikana vyöhykkeillä I (Vantaa) ja IV (Sodankylä). Huomaa pystyakselien erilaiset asteikot. Vaaka-akselina on vuorokauden järjestysnumero (1-365), ja arvoja on yhteensä 8760. 


\subsection{Vertailua käytössä olevaan energialaskennan testivuoteen (TRY2012)}

Taulukkoon 2.2 on koottu käytössä olevan energialaskennan testivuoden (TRY2012) erot nyt tuotettuun testivuoteen (TRY2020) verrattuna. Koska TRY2012 laadittiin jakson 1980-2009 ja TRY2020 jakson 1989-2018 pohjalta, mukaan on tullut uusia vuosia, vanhimmat ovat jääneet pois ja Finkelstein-Schafer - parametrien arvot (eli summafrekvenssijakaumien poikkeamat pitkäaikaisista keskiarvoista) ovat muuttuneet. Uusi testivuosi TRY2020 koostuu Vantaalla 7, Jyväskylässä 10 ja Sodankylässä 11 uudesta tyyppikuukaudesta, ja loput ovat samoja kuin TRY2012:ssa. Jokioisten säähavaintoja ei käytetty TRY2012:n muodostamiseen, vaan myös vyöhykkeelle II käytettiin Vantaan tietoja; uudessa TRY2020:ssa on vyöhykkeelle II aiempaan verrattuna 9 uutta tyyppikuukautta.

Taulukko 2.2: Energialaskennan testivuosien TRY2020 ja TRY2012 vertailu vyöhykkeillä I-IV. Varjostus tarkoittaa, että vuosi, jolta kyseisen kalenterikuukauden sääaineisto on peräisin, on pysynyt samana. Testivuotta TRY2012 ei määritetty aiemmin erikseen vyöhykkeelle II, vaan myös sille käytettiin samoja säähavaintoja kuin vyöhykkeellä I.

\begin{tabular}{lrrrrrrrrrrrrr}
\hline TRY2020 & \multicolumn{1}{c}{$\begin{array}{c}\text { Kuukausi } \\
\text { Vyöhyke }\end{array}$} & 1 & 2 & 3 & 4 & 5 & 6 & 7 & 8 & 9 & 10 & 11 & 12 \\
\hline I (Vantaa) & 2002 & 1998 & 2004 & 2012 & 2006 & 2005 & 1989 & 2003 & 1998 & 2012 & 2006 & 1998 \\
II (Jokioinen) & 2002 & 1998 & 2004 & 2012 & 2011 & 2005 & 1989 & 1994 & 1998 & 2004 & 2006 & 1998 \\
III (Jyväskylä) & 2002 & 2003 & 1999 & 1991 & 2012 & 1996 & 2009 & 1990 & 1998 & 2014 & 2006 & 1998 \\
IV (Sodankylä) & 1998 & 1997 & 2009 & 1999 & 1993 & 2010 & 2013 & 2011 & 2012 & 2013 & 2017 & 2015 \\
\hline TRY2012 & & & & & & Kuukausi & & & & & \\
Vyöhyke & 1 & 2 & 3 & 4 & 5 & 6 & 7 & 8 & 9 & 10 & 11 & 12 \\
\hline I (Vantaa) & 1990 & 1998 & 1994 & 2009 & 2006 & 2005 & 2008 & 2003 & 1997 & 1981 & 1989 & 1998 \\
II (Vantaa) & 1990 & 1998 & 1994 & 2009 & 2006 & 2005 & 2008 & 2003 & 1997 & 1981 & 1989 & 1998 \\
III (Jyväskylä) & 1984 & 2004 & 2008 & 1991 & 2008 & 1985 & 2009 & 1980 & 1997 & 1998 & 2007 & 1983 \\
IV (Sodankylä) & 1988 & 1983 & 1985 & 2009 & 2007 & 1988 & 1991 & 2004 & 2003 & 1995 & 1981 & 1997 \\
\hline
\end{tabular}

Kuvat 2.5-2.6 esittävät kunkin kalenterikuukauden ja keskimäärin koko vuoden lämpötilaa ja kokonaissäteilyä koskevia vertailutuloksia testivuosien TRY2020 ja TRY2012 sekä koko tutkitun jakson (1989-2018) välillä vyöhykkeillä I ja IV. Vastaavat vertailut vyöhykkeille II ja III on tehty liitteen 3 kuvissa L3.2-L3.3.

Vantaalla, Jyväskylässä ja Sodankylässä TRY2020 on koko vuotta ajatellen $0.17-0.36{ }^{\circ} \mathrm{C}$ lämpimämpi kuin TRY2012, vaikka joinakin yksittäisinä kuukausina se onkin viileämpi. Vyöhykkeen II tulokset poikkeavat muista vyöhykkeistä, sillä TRY2012:ssa sille käytettiin Jokioista korkeampia Vantaan lämpötiloja; kyseessä ovat siis erot paikan eikä ajan suhteen. Kaikilla vyöhykkeillä TRY2020 on lähempänä 30-vuotiskeskiarvoa kuin mitä TRY2012 on, joskin molempien testivuosien erot pitkäaikaisesta keskilämpötilasta jäävät tarkastelujakson aikana tapahtuneen vuosien välisen keskihajonnan piiriin. (kuva 2.5 ja liitteen 3 kuva L3.2).

Kokonaissäteilyn vuosikeskiarvojen erot uuden ja aiemman testivuoden välillä ovat pienehköjä. Kuukausitasolla löytyy joitakin selvempiä eroja. Esimerkiksi vyöhykkeellä III tulee touko- ja kesäkuussa hieman vähemmän auringonsäteilyä uudessa testivuodessa TRY2020 kuin TRY2012:ssa, mikä kertoo suuremmasta pilvisyydestä. (kuvat 2.6 ja L3.3). 

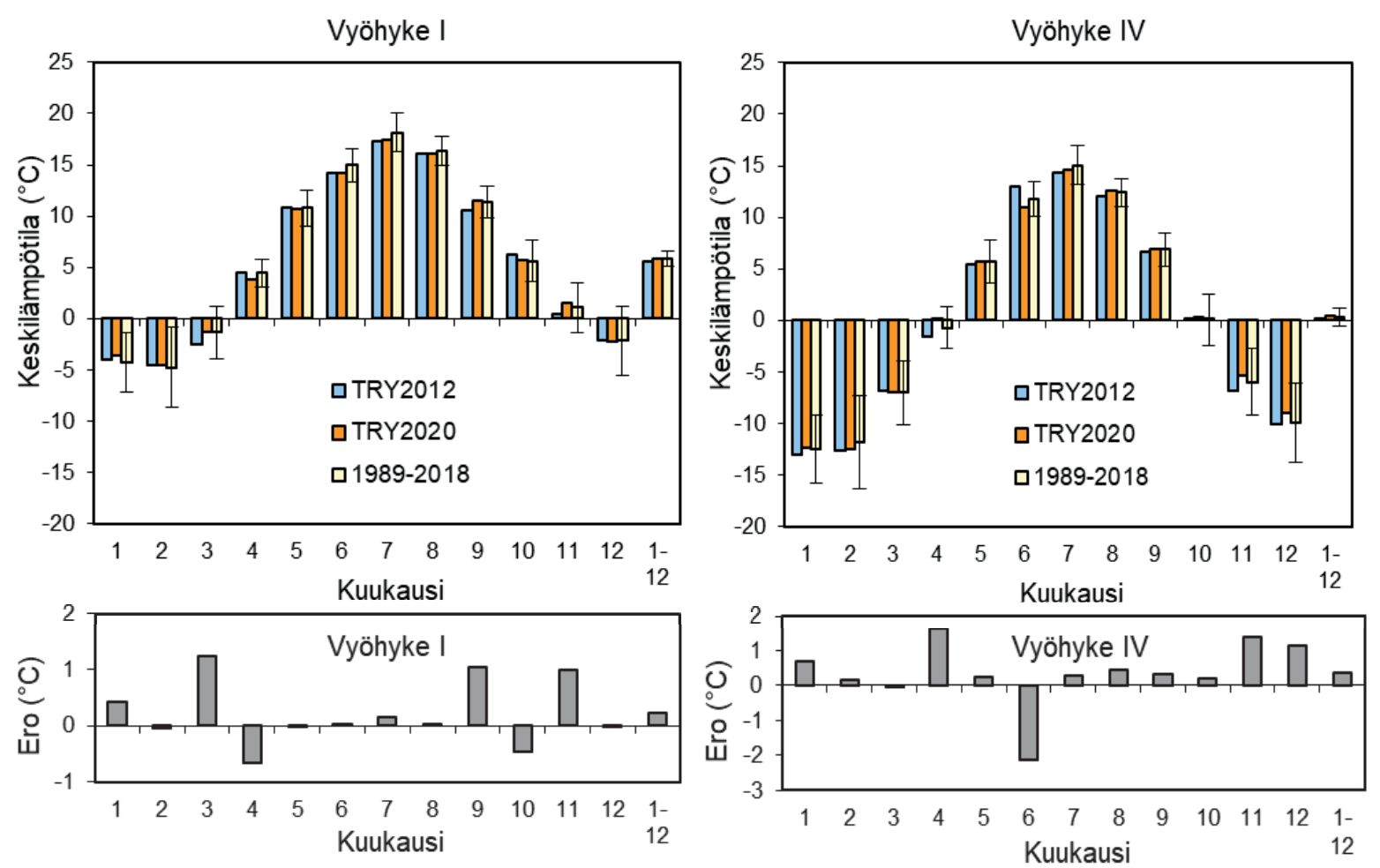

Kuva 2.5: Uuden testivuoden TRY2020 vertailua testivuoteen TRY2012 vyöhykkeillä I ja IV: eri kuukausien ja koko vuoden keskilämpötila. Lisäksi on esitetty jakson 1989-2018 pitkäaikaiset keskiarvot sekä pystyjanoina yhden keskihajonnan suuruiset poikkeamat siitä kylmään ja lämpimään suuntaan. Vuoden keskilämpötila esitetään pylväillä "1-12”. Alemmalla rivillä ovat testivuosien erotukset (TRY2020-TRY2012).
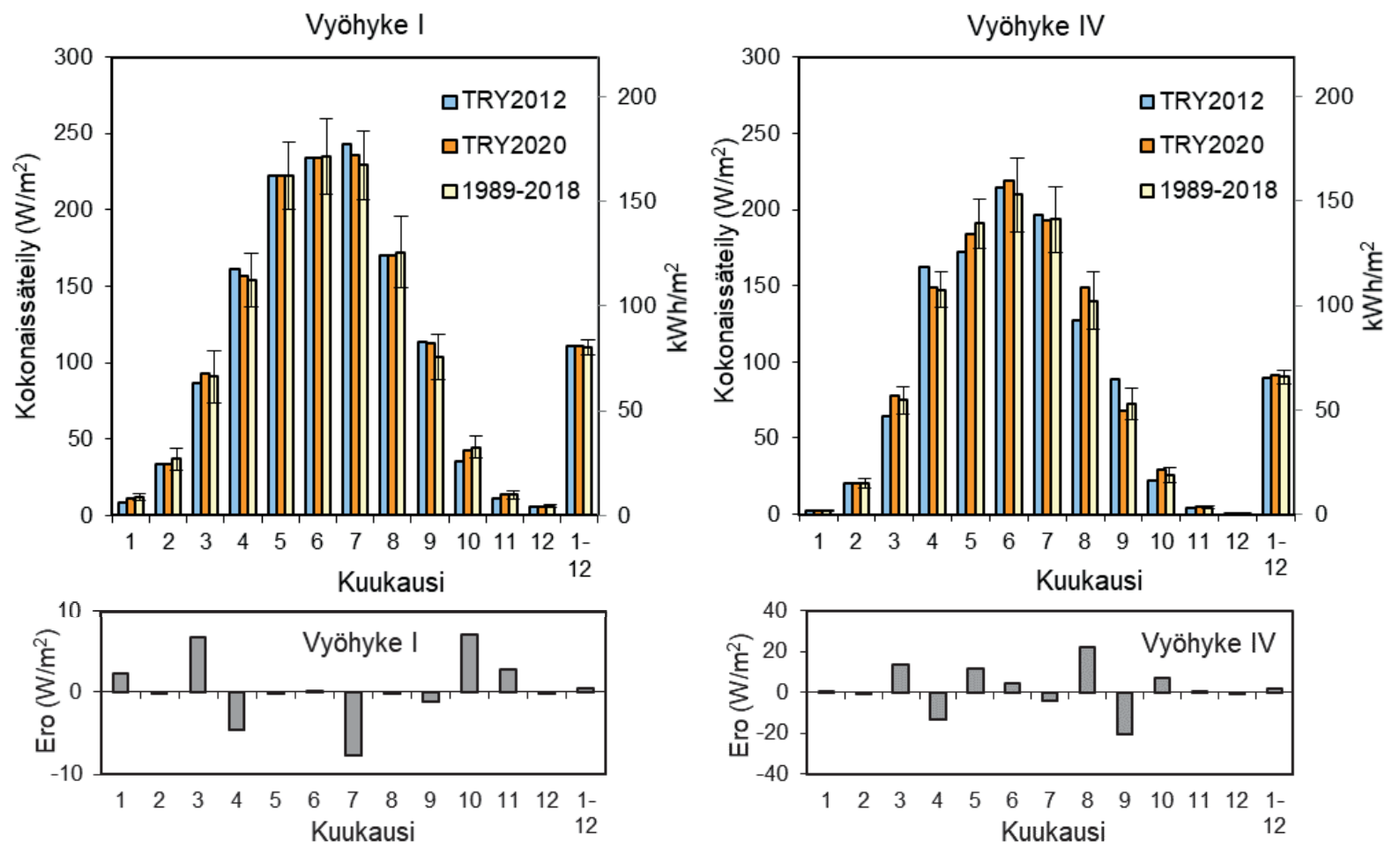

Kuva 2.6: Sama kuin kuvassa 2.5, mutta auringon kokonaissäteilylle. 


\subsection{Rakennusfysikaalisten tarkastelujen vertailuvuosi}

Rakennusfysikaalisten tarkastelujen vertailuvuotta varten koottiin erikseen Jokioisten tunnittaiset automaattisiin mittauksiin perustuvat säähavainnot vuodelta 2015. Kuten luvussa 2.1 todettiin liitteessä 2 esitetyn vertailun perusteella, tässä työssä käytetty tuntisademäärien epäsuora arviointimenetelmä kuvaa varsin hyvin tuntisateiden tilastollisia ominaisuuksia. On kuitenkin syytä pitää mielessä, että suoriin tunnittaisiin mittauksiin perustuvat rakennusfysikaalisten tarkastelujen vertailuvuoden tunnittaiset sadetiedot (kuva 2.7a) ovat luotettavampia kuin epäsuorasti laadittu sademäärän aikasarja vuodelle 2015 Jokioisten 30-vuotisaineistossa. Sama koskee epäilemättä muidenkin sääsuureiden aikasarjoja, frekvenssijakaumia ja eri suureiden mahdollisia keskinäisiä riippuvuuksia (esimerkkejä kuvassa 2.7).

On tärkeä huomata, että Jokioisten vuoden 2015 sääaineiston soveltuvuutta erilaisiin rakennusfysikaalisiin tarkasteluihin ei ole testattu tätä raporttia tehtäessä. Siten kyseistä aineistoa ei voi pitää rakennusfysiikan testivuotena, vaan se on luotu rakennusfysikaalisten tarkastelujen tueksi ja vertailuja varten. Myöhemmin esitettävän kuvan 4.3 perusteella nähdään kuitenkin, että etenkin vertailuvuoden tammikuu ja joulukuu olivat hyvin sateisia (tuolloin satoi $75-85 \%$ tavanomaista enemmän) ja joulukuun keskilämpötila oli $4.5^{\circ} \mathrm{C}$ korkeampi kuin keskimäärin tuona kuukautena jakson 1989-2018 aikana. Lisätietoa Jokioisten sateista ja poutajaksoista v. 2015 on myös liitteen 2 luvussa L2.3.2.

a) Jokioinen 2015

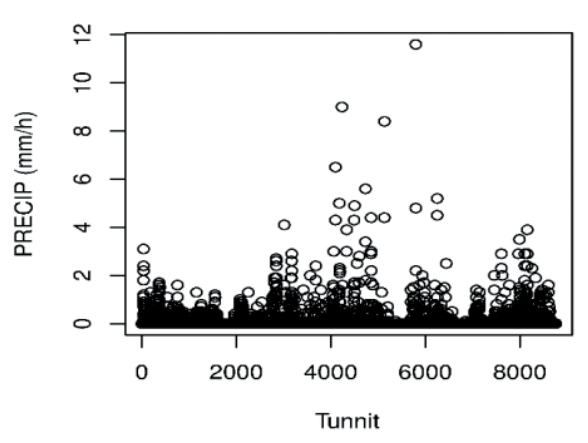

c) Jokioinen 2015

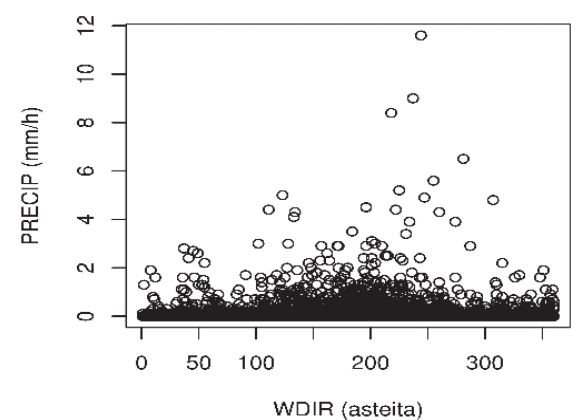

b) Jokioinen 2015

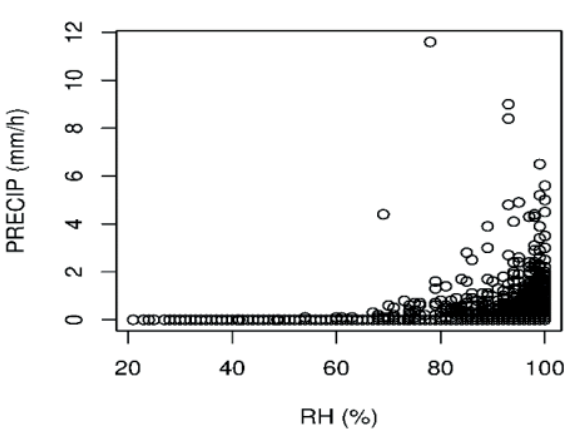

d) Jokioinen 2015

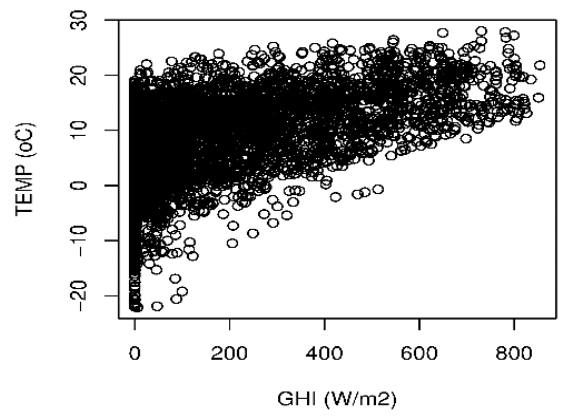

Kuva 2.7: Rakennusfysikaalisten tarkastelujen vertailuvuoden mitattuja tunnittaisia säähavaintoja. a) Sademäärän $(\mathrm{mm} / \mathrm{h})$ vuotuinen kulku. Vaaka-akselina on tunnin järjestysnumero vuoden alusta lukien. b) Sademäärä $(\mathrm{mm} / \mathrm{h})$ ilman suhteellisen kosteuden (\%) funktiona. c) Sademäärä tuulen suunnan funktiona $\left(90^{\circ}=\right.$ itätuuli, $180^{\circ}=$ etelätuuli, $270^{\circ}=$ länsituuli, $360^{\circ}$ = pohjoistuuli). d) Lämpötila $\left({ }^{\circ} \mathrm{C}\right)$ auringon kokonaissäteilyn $\left(\mathrm{W} / \mathrm{m}^{2}\right)$ funktiona. Diagrammit perustuvat automaattisiin mittauksiin Jokioisissa vuoden 2015 aikana, ja niissä on pisteitä yhteensä 8760. 


\section{Tulevaisuuden ilmaston säätietojen arviointimenetelmät}

\subsection{Aikasarjatiedostojen laatiminen}

Sääsuureitten tunnittaiset 30-vuotiset aikasarjat tulevaisuuden ilmastoa varten laadittiin jokaiselle neljälle paikkakunnalle (Vantaa, Jokioinen, Jyväskylä ja Sodankylä) tarkastellen erikseen kolmea vaihtoehtoista kasvihuonekaasuskenaariota (RCP2.6, RCP4.5 ja RCP8.5; katso kuvaa 1.4). Kaikissa tapauksissa tiedot tuotettiin kolmelle ajanjaksolle, jotka vastaavat vuosien 2030, 2050 ja 2080 vaiheilla vallitsevaa ilmastoa. Yhteensä muodostettiin siis 4x3x3= 36 aikasarjatiedostoa. Näitä tulevaisuuden säätietoja laadittaessa hyödynnettiin ns. deltamenetelmää, mikä tarkoittaa sitä, että pohjana käytettiin todellisiin havaintoihin perustuvia säämuuttujien aikasarjoja perusjakson ajalta (luku 2.1). Nämä aikasarjat sitten muunnettiin ilmastomallien antamien ennusteitten perusteella kuvaamaan simuloitua tulevaa ilmastoa.

Muunnettaessa havaintotietoja kuvaamaan tulevaa ilmastoa tarvitaan aluksi ilmastomallien tuloksista laskettu arvio, miten eri ilmastosuureitten keskimääräiset arvot, ajalliset keskihajonnat ym. muuttuvat tulevaisuudessa. Näiden muutosten laskemisesta ja menetelmästä, jonka avulla eri suureitten tunnittaiset aikasarjat muunnettiin vastaamaan tulevaisuuden ilmastoa, on kerrottu tarkemmin liitteessä 4 .

Tulevaisuutta kuvaavien säätietojen tulkinnassa on oltava tarkkana. Vaikka tutkimuksessa käytetyn muunnosmenetelmän avulla saadaan näennäisesti tuotettua vuosia 2030, 2050 ja 2080 ympäröiville 30-vuotisjaksoille hetkellistä säähavaintotietoa tunnin välein, ei näitä tietoja millään muotoa pidä tulkita ennusteina juuri kyseisille päiville ja ajanhetkille. Yksittäisten simuloitujen arvojen asemesta pitää tarkastella koko 30-vuotisen aikasarjan tilastollisia ominaisuuksia.

\subsection{Ilmastosuureitten kuukausikeskiarvojen muutokset}

Vaikka tulevaisuuden ilmastoa vastaavat säätiedot oli tuotettu kolmelle RCP-skenaariolle, tässä kappaleessa keskitytään tietomäärän hallitsemiseksi RCP4.5-skenaarioon. Kuukausikeskiarvojen muutokset Vantaalla, Jokioisissa, Jyväskylässä ja Sodankylässä siirryttäessä perusjaksosta vuosien 2030, 2050 ja 2080 ilmastoon on esitetty liitteen 5 taulukossa L5.1 seuraaville suureille: lämpötila ja sen keskihajonta, suhteellinen kosteus, tuulen nopeus, auringon kokonaissäteily, suora säteily auringon sädettä vastaan kohtisuoralle pinnalle, hajasäteily ja sademäärä. Havainnollisuuden vuoksi Jyväskylän kuukausikeskiarvojen muutoksia on lisäksi näytetty myös kuvina (kuva 3.1).

Vuotuinen keskilämpötila nousee RCP4.5-skenaarion toteutuessa vuoteen 2030 mennessä runsaalla asteella, vuoteen 2050 noin kaksi astetta ja vuoteen 2080 noin 2.5 astetta, Sodankylässä kuitenkin kolmella asteella. Lämpeneminen on siis voimakkainta pohjoisessa. Eniten lämpötila kohoaa talvisin, kun taas keskikesällä lämpötilan nousu jää runsaaseen puoleen talvikuukausien lukemista.

Lämpötilat vaihtelevat tulevaisuudessa kesää lukuun ottamatta nykyistä vähemmän. Marrasmaaliskuussa lämpötilojen ajallinen keskihajonta putoaisi 2080-luvulle tultaessa eri kuukausina ja eri paikkakunnilla 11-21 prosenttia. Touko-elokuussa muutosta on vain muutama prosentti jompaan kumpaan suuntaan. 

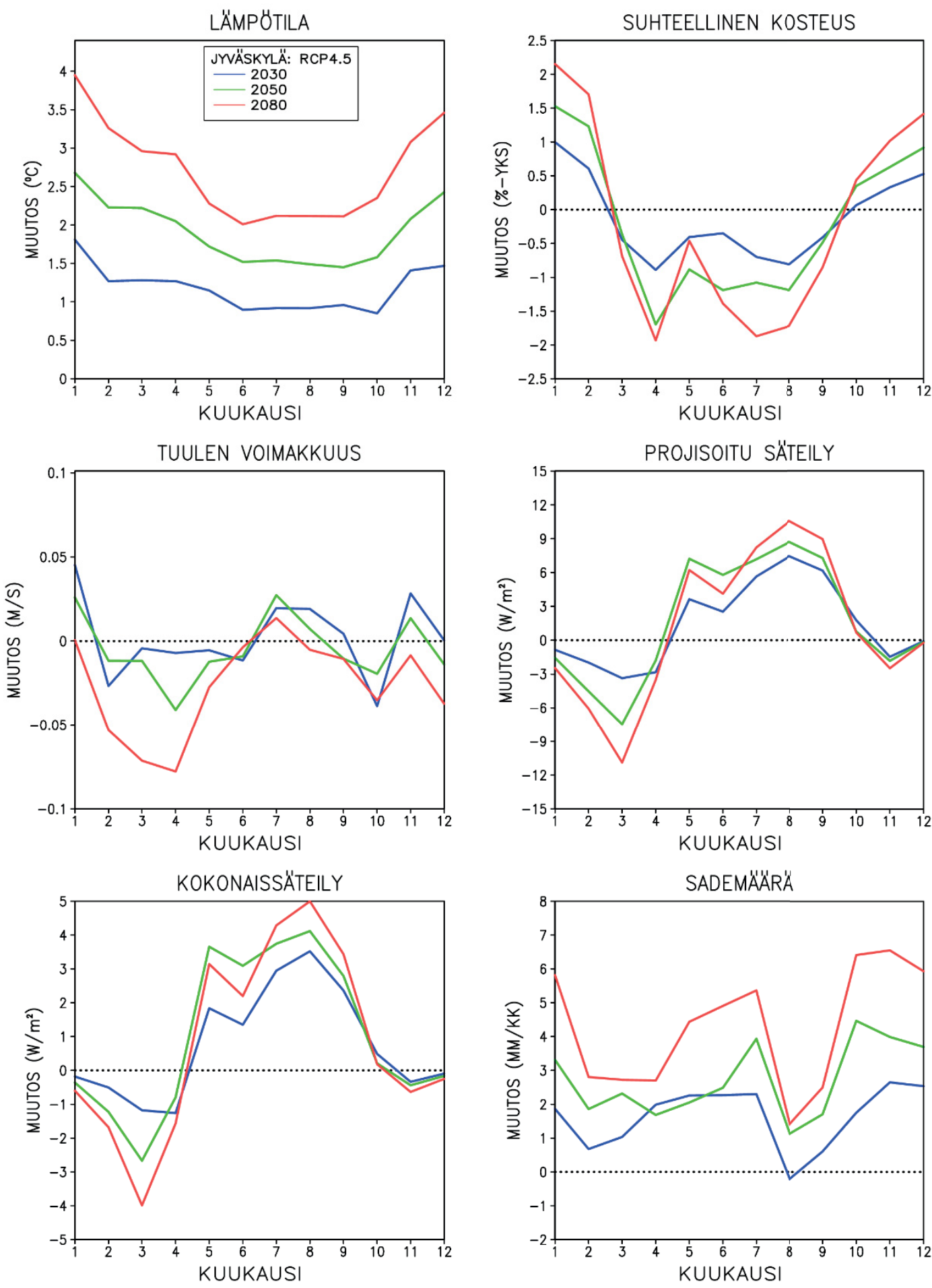

Kuva 3.1: Lämpötilan, suhteellisen kosteuden, tuulen nopeuden, auringon sädettä vastaan kohtisuoralle pinnalle saatavan suoran säteilyn, vaakasuoralle pinnalle tulevan kokonaissäteilyn ja sademäärän muutosten kuukausikeskiarvot Jyväskylässä siirryttäessä perusjaksosta 1989-2018 RCP4.5-skenaarion mukaiseen vuoden 2030 (sininen käyrä), 2050 (vihreä käyrä) ja 2080 (punainen käyrä) ilmastoon. Huomattakoon eri asteikko projisoitua (DNI) ja kokonaissäteilyä (GHI) esittävissä kuvissa. 
Suhteellinen kosteus on vuosisadan loppuvuosikymmeninä talvisin noin 1-3 prosenttiyksikköä nykyistä korkeampi. Muutos on suurin pohjoisessa. Tämä kosteuden kohoaminen on kylläkin laskennallista: lämpötilojen noustessa pitää alijäähtyneen veden suhteen laskettua kosteutta nostaa pakkassäällä, jotta jään suhteen laskettu kosteus muuttuisi sen mukaisesti kuin mallit ennustavat. Kesällä muutokset ovat pieniä, ja varsinkin etelässä ilma muuttuu jopa hieman kuivemmaksi. Keskimääräinen tuulen nopeus muuttuu hyvin vähän, ja useimpina kuukausina on tämän skenaarion mukaan odotettavissa aavistuksenomaista tuulten heikentymistä.

Auringon kokonaissäteilystä katoaisi vuosisadan loppuun mennessä talvikuukausina noin $5 \%$; Sodankylässä marras-joulukuussa yli $10 \%$. Kesäpuolella vuotta auringonpaiste taas aavistuksen lisääntyy. Muutos on suurin syyskuussa, Vantaalla jopa $+5 \%$. Muutokset ovat suurimpia auringon sädettä vastaan kohtisuoralle pinnalle tulevassa suorassa säteilyssä, hajasäteilyssä taas selvästi pienempiä. Tämä saattaa kylläkin osittain johtua käytetystä laskentamenetelmästä. Talvella säteilyä saadaan hyvin vähän, joten isoiltakin vaikuttavat prosenttimuutokset ovat absoluuttisesti melko vähäisiä (kuva 3.1). Energiayksiköissä ilmaistuna säteily muuttuu eniten valoisana vuodenaikana.

Sademäärä lisääntyy kaikkina vuodenaikoina, eniten talvella, jolloin lisäys on reilut $10 \%$. Kesällä ja alkusyksyn aikana muutokset ovat pienempiä. Kahden ensimmäisen jakson sademäärissä nähdään elokuussa etelässä jopa pientä vähenemistä. Tämä on kuitenkin tulkittava hälyn aikaansaannokseksi. Sademääräthän vaihtelevat sekä malleissa että luonnossa suuresti vuodesta ja vuosikymmenestä toiseen, joten itseisarvoltaan pienet muutokset eivät yleensä ole tilastollisesti merkitseviä.

Kaikissa niissä tapauksissa, joissa muutossignaali on merkittävä, muutos etenee ajan suhteen monotonisesti, ts. muutos on itseisarvoltaan pienin vuoden 2030 ja suurin vuoden 2080 ilmastossa. Varsinkin vuosisadan lopulla RCP8.5-skenaario tuottaa järjestään suurempia ja $\mathrm{RCP} 2.6$ pienempiä muutoksia kuin RCP4.5.

Kuvassa 3.1 ja liitteen taulukossa L5.1 esitetyt ilmastolliset muutokset ovat lähes kauttaaltaan selvästi pienempiä kuin aeimmin rakennusfysikaalisten testivuosien laadintaa varten tehdyssä raportissa (Ruosteenoja ym., 2013) esitetetyt vastaavat arvot. Tärkein syy eroihin on, että uudet tulokset perustuvat RCP4.5-skenaarioon, jonka mukaan kasvihuoneilmiö voimistuu selvästi vähemmän kuin aiemmin käytetyssä SRES A2-skenaariossa. Kaukaisinta tarkastelujaksoa on myös hilattu 20 vuotta taaksepäin, eli se ajoittuu nyt vuoden 2080 eikä vuoden 2100 ympärille. Hieman asiaan vaikuttaa myös se, että nyt vertailukohtana käytetty perusjakso on yhdeksän vuotta myöhäisempi kuin aiemmassa raportissa.

\subsection{Ilmastosuureitten frekvenssijakaumia}

Aikasarjoista lasketut lämpötilan ja suhteellisen kosteuden sekä tuulen nopeuden ja suunnan frekvenssijakaumat Jyväskylässä on esitetty kuvissa 3.2 ja 3.3. Koska vuosisadan alkupuolella ja puolivälin tienoilla muutokset ovat vielä melko pieniä, frekvenssit on esitetty ainoastaan perusjaksolle 1989-2018 ja vuoden 2080 ilmastolle. Säteilysuureille tämänkaltainen frekvenssiesitys ei olisi yhtä havainnollinen, koska niille ylivertaisesti yleisin arvo on nolla, aina auringon ollessa maillaan. 

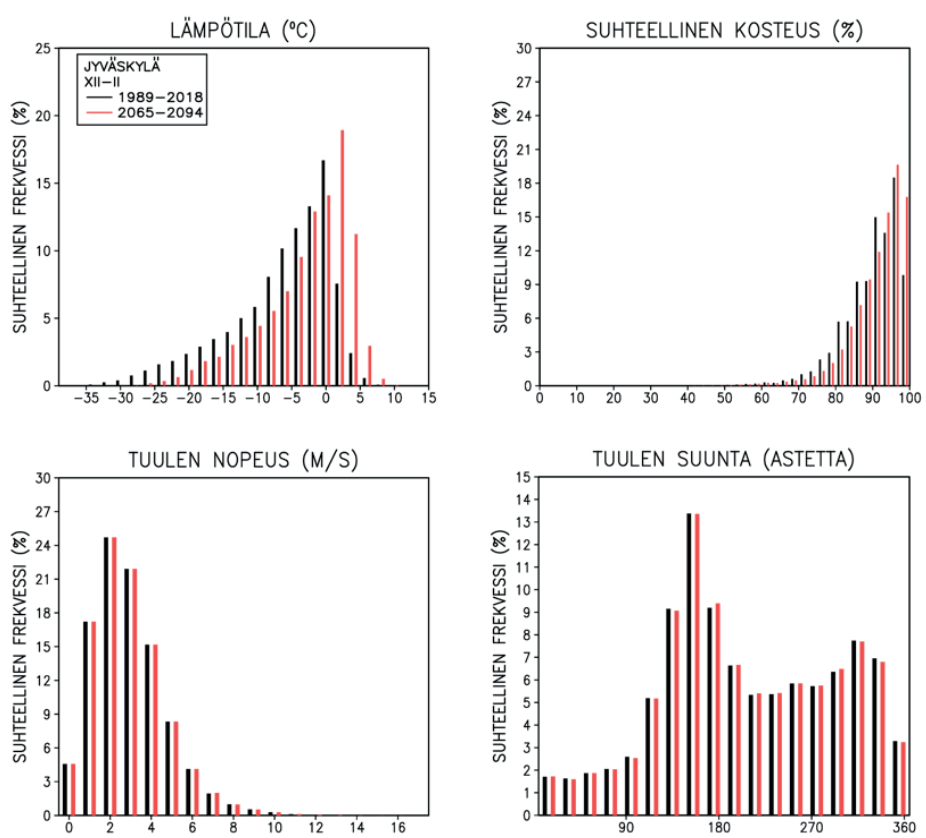

Kuva 3.2: Lämpötilan, suhteellisen kosteuden sekä tuulen nopeuden ja suunnan tunnittaisten arvojen suhteelliset frekvenssijakaumat (prosentteina) Jyväskylässä 30-vuotisjakson 19892018 havaintotietojen perusteella (mustat pylväät) ja vuoden 2080 tienoilla vallitsevassa RCP4.5-skenaarion mukaisessa ilmastossa (punaiset pylväät) joulu-helmikuussa. Luokitteluväli on lämpötilalle $2^{\circ} \mathrm{C}$, kosteudelle $2.5 \%$, tuulen nopeudelle $1 \mathrm{~m} / \mathrm{s}$ ja tuulen suunnalle $20^{\circ}$.

Lämpötilojen jakauma siirtyy ilmaston muuttuessa odotetusti oikealle, samalla kun talvella myös vaihtelevaisuus vähenee. Kesällä vaihtelujen amplitudi pysyy jotakuinkin ennallaan. Ankarimmat pakkaset siis leudontuvat huomattavasti, mutta huippuhelteet eivät tukaloidu samassa suhteessa. Vuoteen 2080 tultaessa koko 30-vuotisjakson alhaisin lämpötila Jyväskylässä kohosi liitteessä 4 esitettyä muunnosmenetelmää sovellettaessa noin kahdeksalla, korkein lämpötila vain noin kahdella asteella.

Suhteellisissa kosteuksissa talvisin 90 ja $100 \%$ :n välillä olevat arvot selvästi yleistyvät alhaisempien kosteuksien kustannuksella. Tämä johtuu osaksi pakkasten heikentymisestä: kohtalaisella tai kovalla pakkasella näin korkeita alijäähtyneen veden suhteen laskettuja kosteuksia ei ole mahdollista esiintyä. Kesällä suhteellinen kosteus vastaavasti keskimäärin alentuu, ja sen tähden pieniä kosteuden arvoja esiintyy tulevaisuudessa nykyistä useammin.

Tuulen voimakkuuksien ja suuntien jakaumissa muutokset ovat varsin vähäisiä. Tuulet siis puhaltelevat tulevaisuudessa suunnilleen yhtä kovaa ja samoilta suunnilta kuin nykyisinkin.

Sademäärien frekvenssijakaumia tutkittaessa ei ole kovin mielekästä katsoa tunnin välein esitettyjä arvoja, sillä näin lyhyen aikavälin sademäärä on kaikkein tavallisimmin pyöreä nolla. Sen asemesta kuvassa 3.4 on esitetty vuorokauden kokonaissademäärien tilastollisia jakaumia. Useimmissa luokissa muutokset ovat melko pieniä. Runsassateiset päivät kuitenkin lisääntyisivät, ja erityisesti yli 12 millimetrin vuorokausisademääriä esiintyisi muunnosmenetelmää sovellettaessa talvisin lähes kolme kertaa niin paljon kuin nykyään. 

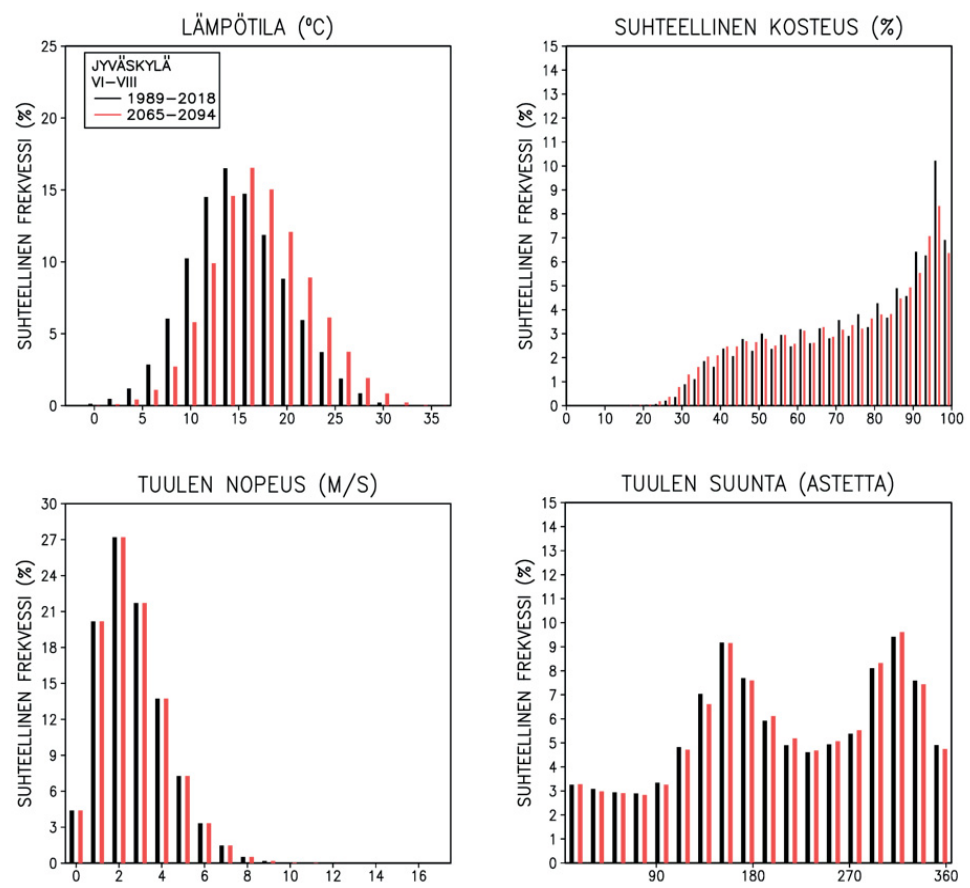

Kuva 3.3: Lämpötilan, suhteellisen kosteuden sekä tuulen nopeuden ja suunnan suhteelliset frekvenssijakaumat Jyväskylässä perusjakson 1989-2018 havaintojen perusteella (mustat pylväät) ja vuoden 2080 tienoilla vallitsevassa RCP4.5-skenaarion mukaisessa ilmastossa (punaiset pylväät) kesä-elokuussa.
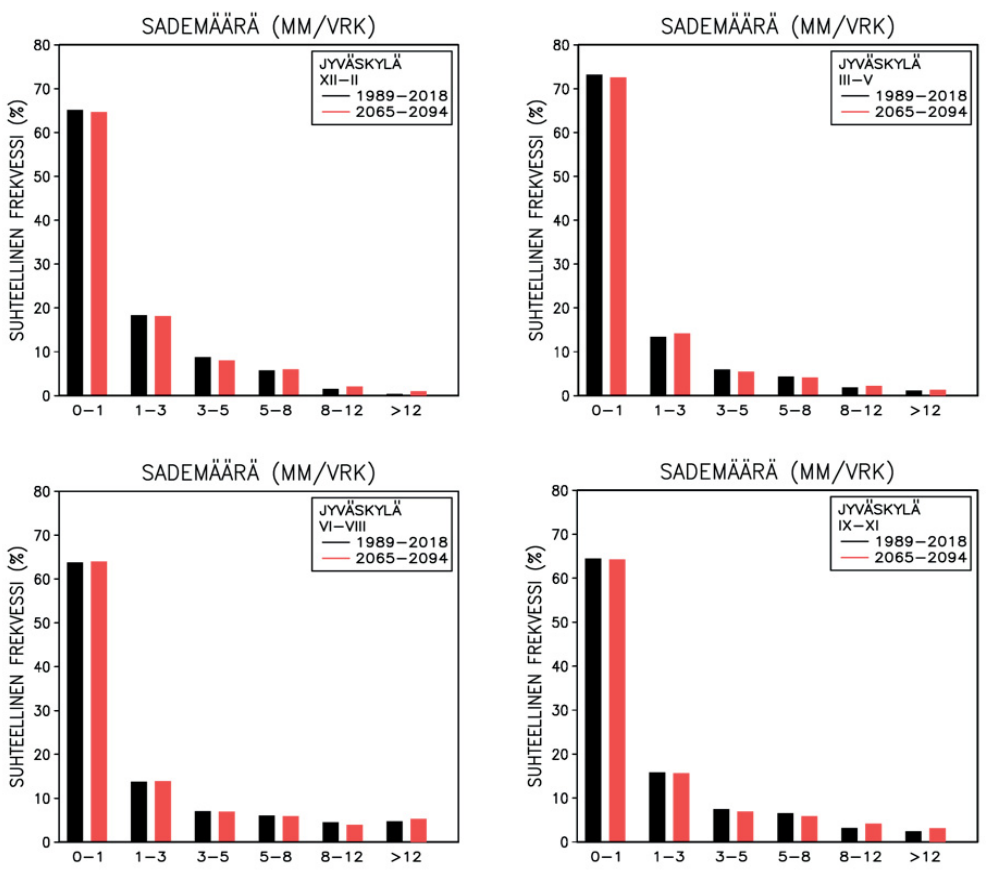

Kuva 3.4: Vuorokauden sadesumman suhteelliset frekvenssijakaumat (prosentteina) Jyväskylässä jakson 1989-2018 havaintotiedoista laskettuina (mustat pylväät) ja arvio vuoden 2080 tienoilla vallitsevassa RCP4.5-skenaarion mukaisessa ilmastossa (punaiset pylväät) eri vuodenaikoina (XII-II: talvi; III-V: kevät; VI-VIII: kesä; IX-XI: syksy). Luokittelu: 0-1 $\mathrm{mm} / \mathrm{vrk}, 1-3 \mathrm{~mm} / \mathrm{vrk}, 3-5 \mathrm{~mm} / \mathrm{vrk}, 5-8 \mathrm{~mm} / \mathrm{vrk}, 8-12 \mathrm{~mm} / \mathrm{vrk}$ ja yli $12 \mathrm{~mm} / \mathrm{vrk}$. 


\subsection{Menetelmien ja tulosten arviointia}

Tutkimuksessa käytetyn muunnosmenetelmän huomattava vahvuus on, että se säilyttää eri sääsuureitten väliset yhteydet järkevinä myös tulevaan ilmastoon siirryttäessä. Esimerkiksi sateen aikana ilman kosteus on yleensä korkea, auringonpaistetta saadaan vähän ja tuuli puhaltaa tavallista useammin idän tai etelän suunnalta. Kesällä sadesäällä on tyypillisesti viileää, talvella taas leutoa. Aurinkoinen heikkotuulinen korkeapainetilanne vastaavasti tuo talvella pakkasia ja kesällä hellettä.

Muunnosmenetelmä (liite 4) on rakennettu niin, että useimmille sääsuureille tulevaisuuden aikasarjojen 30-vuotiset keskiarvot eri kalenterikuukausina poikkeavat perusjakson ilmastosta täsmälleen samalla tavalla kuin mitä ilmastomallit ennustavatkin. Tämä pätee lämpötilalle, sademäärälle, auringon kokonaissäteilylle, tuulen voimakkuudelle, lämpötilavaihtelun ajalliselle keskihajonnalle ja kesällä myös suhteelliselle kosteudelle. Sen sijaan tuulen suuntien jakaumaa, sadepäivien lukumäärää (sademäärä $\geq 1 \mathrm{~mm} / \mathrm{vrk}$ ) ja sateitten intensiteetti-indeksiä (keskimääräinen sademäärä sadepäivinä) koskevat muutokset toteutuvat muunnetuissa aikasarjoissa vain likimääräisesti tai ainoastaan suuntaa-antavasti verrattuna suoraan ilmastomalleista laskettuihin 30-vuotiskeskiarvoihin.

On tärkeä huomata, että muunnosmenetelmä ei osaa ottaa huomioon frekvenssijakaumien muodon mahdollista muuttumista. Esimerkiksi perusjakson lämpötilojen frekvenssijakaumassa esiintyy hyvin runsaasti arvoja nolla-asteen lähettyvillä; tämä liittyy $\mathrm{mm}$. veden olomuodon muutoksissa sitoutuvaan ja vapautuvaan suureen lämpöenergian määrään. Delta-menetelmää sovellettaessa tämä ns. jakauman räntäpiikki siirtyy lämmenneessä ilmastossa selvästi lämpöasteitten puolelle, kuten nähdään kuvasta 3.2, mutta luultavimmin tämä ei pidä oikeasti paikkaansa.

Sateen tuntiarvojen muodostamiseksi käytetyn menetelmän arvioimiseksi tarkasteltiin sitä, miten hyvin sadepäivien lukumäärän ja sateitten intensiteetti-indeksin muuntaminen uuteen ilmastoon onnistui Jyväskylässä verrattuna suoraan ilmastomalleista saatuihin kalenterikuukausittaisiin arvoihin, joita oli käytetty algoritmin syöttötietoina. Kävi ilmi, että sadepäivien määrän muuntaminen uuteen ilmastoon onnistui enimmäkseen kohtuullisesti. Sen sijaan sateen intensiteetti-indeksille luoduissa aikasarjatiedostoissa muutos erosi tyypillisesti useamman prosenttiyksikön verran tavoitellusta arvosta.

Sadeindeksien muutosten poikkeaminen suorista mallituloksista ei ole periaatteessa yllättävää, sillä sateen voimakkuuksia muuttava algoritmin osa oli melko yksinkertainen. Sateen voimakkuutta korotettiin likimain verrannollisesti havainnosta saadun sateen voimakkuuden neliöön, ensin vuorokausi- ja sitten tuntitasolla. Tälle valinnalle ei ole olemassa mitään syvällistä teoreettista perustelua, mutta ei olisi ollut muunkaanlaiselle vastaavalle yksinkertaistetulle funktionaaliselle riippuvuudelle. Oleellisesti vastaavaa muunnosmenetelmää on kyllä käytetty Aaltosen ym. (2008) työssä.

Mallitulosten mukaan näyttäisi siltä, että tulevaisuudessa sadepäivät ryvästyisivät ainakin kesällä nykyistä voimakkaammin. Sadepäiviä olisi monta peräkkäin, ja niitten väliset poutajaksot vastaavasti pitenisivät. Tähän viittaa Lehtosen (2011) havainto, jonka mukaan kesällä Etelä-Suomessa poutapäivien lukumäärä ei juuri muuttuisi, mutta poutajaksot kuitenkin keskimäärin pidentyisivät jonkin verran. Tällaista muutosta tässä raportissa käytetty muunnosmenetelmä ei kykene ottamaan huomioon. 


\section{Tulevaisuuden ilmaston testi- ja vertailuvuodet}

\subsection{Energialaskennan testivuodet 2030, 2050 ja 2080}

Luvussa 2.2 esiteltyä energialaskennan testivuotta TRY2020 vastaavat tulevaisuuden testivuodet 2030, 2050 ja 2080 kolmen eri kasvihuonekaasuskenaarion tapauksessa muodostettiin seuraavasti. Ensin poimittiin tulevaisuuden ilmaston 30-vuotisten säätietojen aikasarjoista (luku 3) kullekin nykyisen ilmaston testivuoden TRY2020 kalenterikuukaudelle (taulukko 2.1) sille valittua vuotta vastaavat tulevaisuuden sääaineistot. Sen jälkeen eri kuukausien vaihteiden säätiedot tasoitettiin liitteessä 3 kuvatulla tavalla.

Edellä kuvattu tapa poikkeaa hieman menetelmästä, jota käytettiin aiemmin TRY2012:n ilmastoskenaariota laadittaessa (Jylhä ym., 2011); nyt valittua tapaa voidaan pitää laskennallisesti parempana. On kuitenkin hyvä huomata, että joinakin testivuoden kuukausina muutokset TRY2020:sta tulevaisuuteen voivat hieman poiketa 30-vuotiskeskiarvojen muutoksista.

Kuvat 4.1-4.2 esittävät muodostettujen sääaineistojen mukaisia kuukausikeskiarvoja lämpötilalle ja auringon kokonaissäteilyteholle.
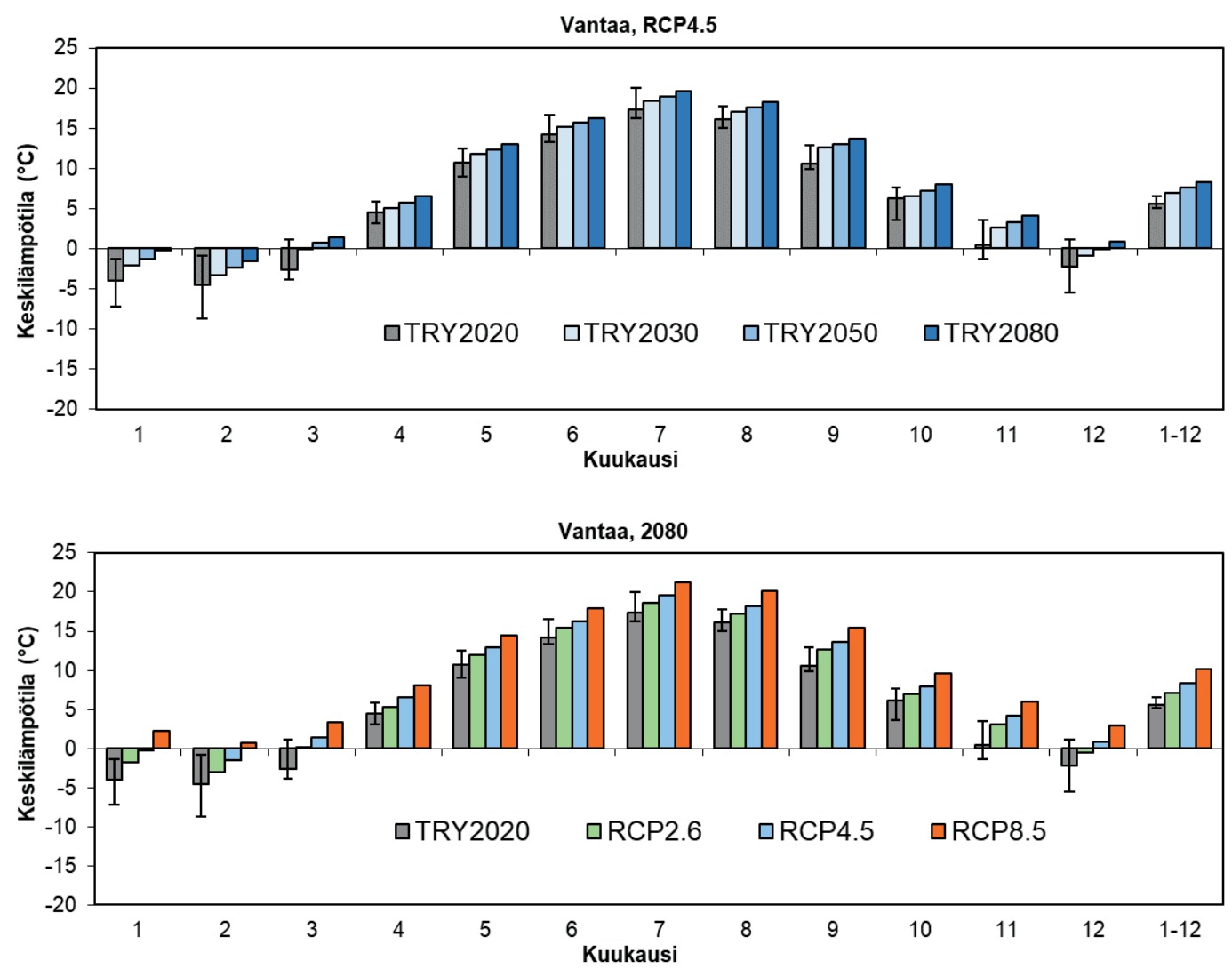

Kuva 4.1: Kuukausien keskilämpötilat vyöhykkeellä I (Vantaa) uutena testivuotena (TRY2020) sekä tulevaisuuden testivuosina 2030, 2050 ja 2080 kasvihuonekaasujen keskiskenaarion (RCP4.5) mukaan (yllä) ja tulevaisuuden testivuotena 2080 kolmen eri kasvihuonekaasuskenaarion (RCP2.6, RCP4.5, RCP8.5) toteutuessa (alla). Pystyjanat näyttävät keskihajonnan suuruisen poikkeaman jakson 1989-2018 keskimääräisistä kuukausikeskilämpötiloista. Vuoden keskilämpötila esitetään viimeisillä pylväillä "1-12”. 

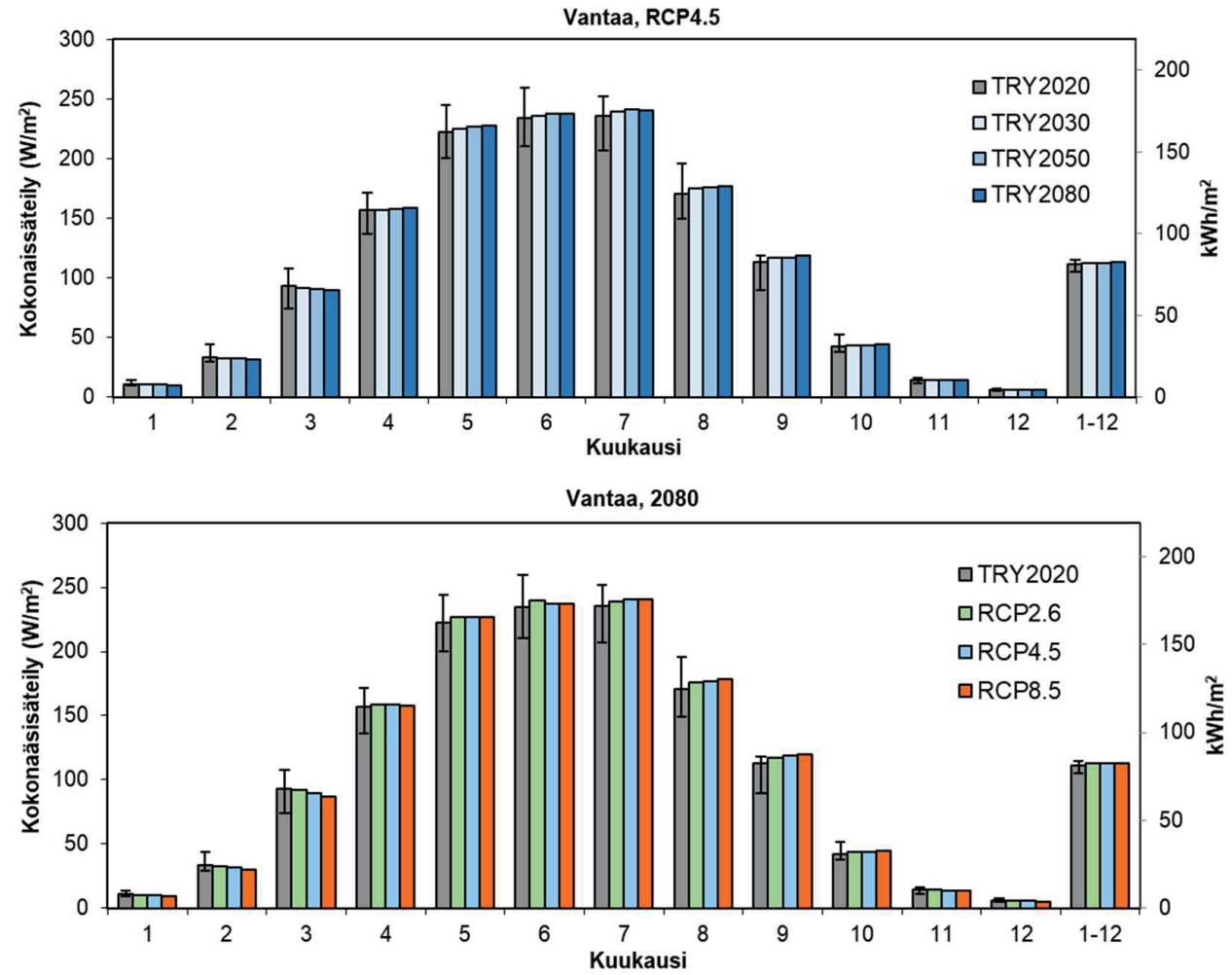

Kuva 4.2: Auringon kokonaissäteily kalenterikuukausittain vyöhykkeellä I (Vantaa) uutena testivuotena (TRY2020) sekä tulevaisuuden testivuosina 2030, 2050 ja 2100

kasvihuonekaasujen keskiskenaarion (RCP4.5) mukaisesti (yllä) ja tulevaisuuden testivuotena 2080 kolmen ei kasvihuonekaasuskenaarion (RCP2.6, RCP4.5, RCP8.5) mukaan (alla).

Pystyjanat näyttävät keskihajonnan suuruisen poikkeaman jakson 1989-2009 havaintojen mukaisesta kuukausikeskiarvosta. Vuoden keskimääräinen kokonaissäteily esitetään viimeisillä pylväillä "1-12".

\subsection{Rakennusfysikaalisten tarkastelujen vertailuvuodet 2030,2050 ja 2080}

Työssä laadittiin myös luvussa 2.4 esitettyä rakennusfysikaalisten tarkastelujen vertailuvuotta vastaavat tulevaisuuden arviot. Tämä tehtiin siten, että Jokioisten nykyisen ilmaston 30vuotisaikasarjoissa (luku 2.1) korvattiin vuoden 2015 interpoloidut arvot todellisilla tunnin välein tehdyillä mittaustuloksilla. Näin muunnettuja perusjakson aikasarjoja käytettiin pohjana muodostettaessa tulevaisuuden 30-vuotisia aikasarjoja vastaavalla tavalla kuin luvussa 3. Lopuksi vuotta 2015 vastaavat tulevaisuuden arviot poimittiin talteen.

Esimerkkinä tuloksista on kuvassa 4.3 esitetty RCP4.5-skenaarion mukaiset vertailuvuoden kuukausikeskiarvot lämpötilalle, sademäärälle, tuulen nopeudelle sekä suhteelliselle kosteudelle tämän vuosisadan loppupuolella. Kuvaan on lisätty myös nykyistä ilmastoa vastaava vertailuvuosi sekä nykyisen ja tulevaisuuden ilmaston 30-vuotiset keskiarvot. Kuten luvussa 2.4 todettiin, vertailuvuoden tammikuu ja joulukuu olivat hyvin sateisia. Koska sateen voimakkuuksia muuttavan algoritmin taustalla on ilmastomallituloksiin perustuva oletus, että 
rankat sateet voimistuvat suhteellisesti ottaen enemmän kuin keskimääräiset ja heikot sateet (vrt. Lehtonen, 2011; Lehtonen ym., 2014a), vertailuvuoden sateisimpien kuukausien sademääriä korotettiin enemmän kuin kyseisten kalenterikuukausien sademääriä keskimäärin.
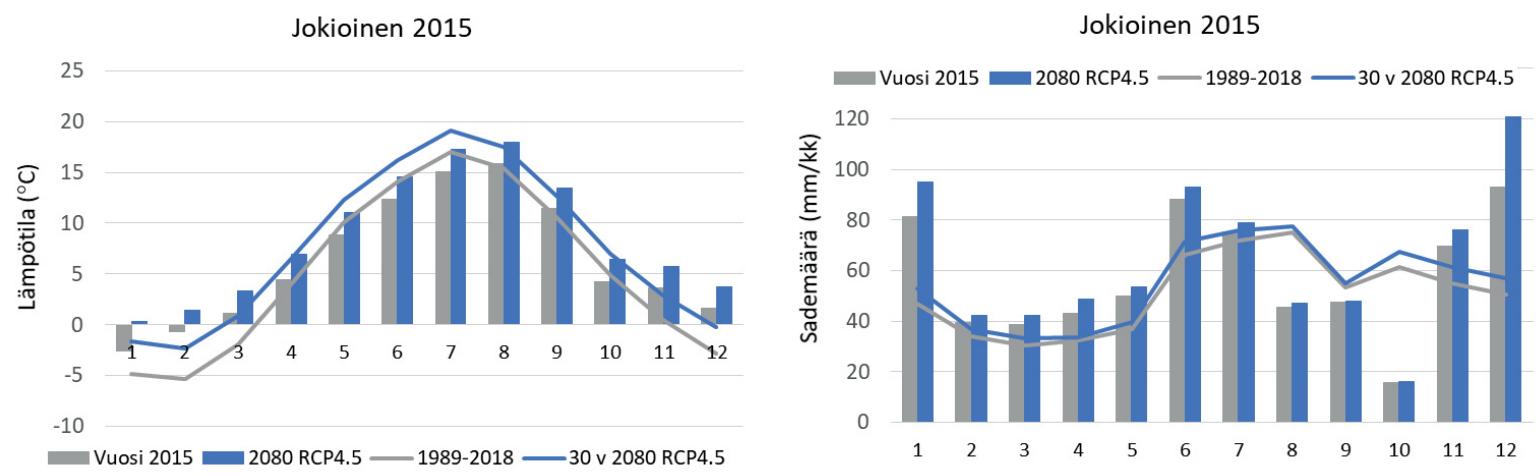

Jokioinen 2015

Vuosi $2015=2080$ RCP4.5 $-1989-2018-30$ v 2080 RCP4.5

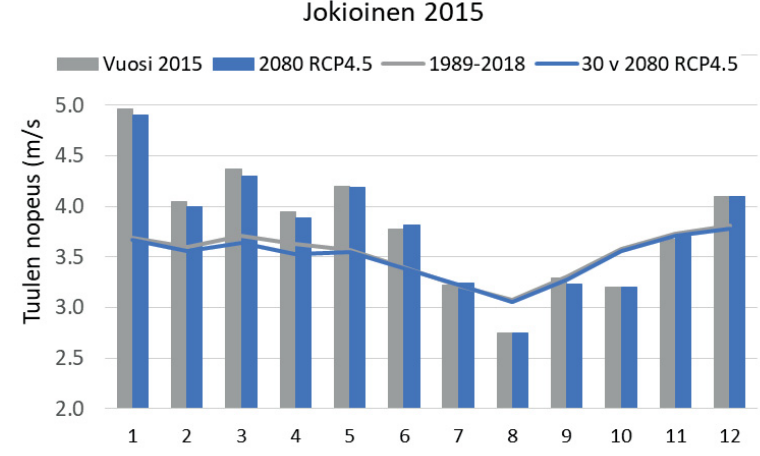

Kuva 4.3: Lämpötilan, sademäärän, tuulen nopeuden ja suhteellisen kosteuden kuukausikeskiarvoja Jokioisissa. Harmaat pylväät esittävät rakennusfysikaalisten tarkastelujen vertailuvuotta (v. 2015) ja siniset sitä vastaavaa tulevaisuuden vuotta 2080 RCP4.5päästöskenaarion mukaan. Vastaavat 30-vuotiskeskiarvot on näytetty käyrien avulla.

\section{Lämpötilan, sademäärän ja tuulen ääri-ilmiöt}

\subsection{Yleistä sään ääri-ilmiöistä}

Sään ääri-ilmiöistä sekä ilmastonmuutoksen vaikutuksista niihin puhutaan nykyään paljon. Esimerkiksi tiedotusvälineissä ääri-ilmiö -termi liitetään usein voimakkaaseen sääilmiöön, joka aiheuttaa tuhoa. On kuitenkin tärkeä ymmärtää, että ääri-ilmiö -termille ei ilmakehätieteissä ole yksikäsitteistä määritelmää, vaan se voidaan määrittää usealla eri tavalla. Lisäksi kaikilla säämuuttujilla tai -ilmiöillä on oma ns. "ääripäänsä", eikä termi liity pelkästään esimerkiksi myrskyihin tai rajuilmoihin. Alla on kuvattu joitakin tapoja, joiden mukaan ääri-ilmiö voidaan määrittää:

- Maksimi/minimi: jonkin säämuuttujan arvojen jakautuman suurin ja pienin arvo.

- Toistuvuus tai esiintymistodennäköisyys: kuinka harvinainen säämuuttujan arvo on (esimerkiksi kerran sadassa vuodessa esiintyvä).

- Vaikutukset: kuinka paljon vahinkoa jokin ilmiö aiheutti. Vaikutustietoja käytetään määrittelyssä etenkin silloin, kun säämittauksia ilmiön voimakkuudesta ei ole saatavilla. 
Kun ilmasto muuttuu, muuttuvat myös säämuuttujien tilastolliset jakautumat. Tämä puolestaan johtaa esimerkiksi siihen, että menneessä ilmastossa (siis vaikkapa jaksolla 1961-1990) erittäin harvinaiset korkeat lämpötilat eivät nykyilmastossa saati tulevaisuudessa ole enää yhtä harvinaisia kuin ennen, ja toisaalta uusien maksimilämpötilojen esiintymisen todennäköisyys kasvaa. Kuvassa 5.1 puolestaan nähdään, kuinka ilmastonmuutoksen arvioidaan vaikuttavan lyhytkestoisten 3-tunnin rankkasateiden esiintymiseen Suomen pääkaupunkiseudulla: esimerkiksi menneessä ilmastossa erittäin harvinaiset kerran 100 vuodessa esiintyvät sateet esiintyvät vuosisadan loppupuolella kerran 30 vuodessa.

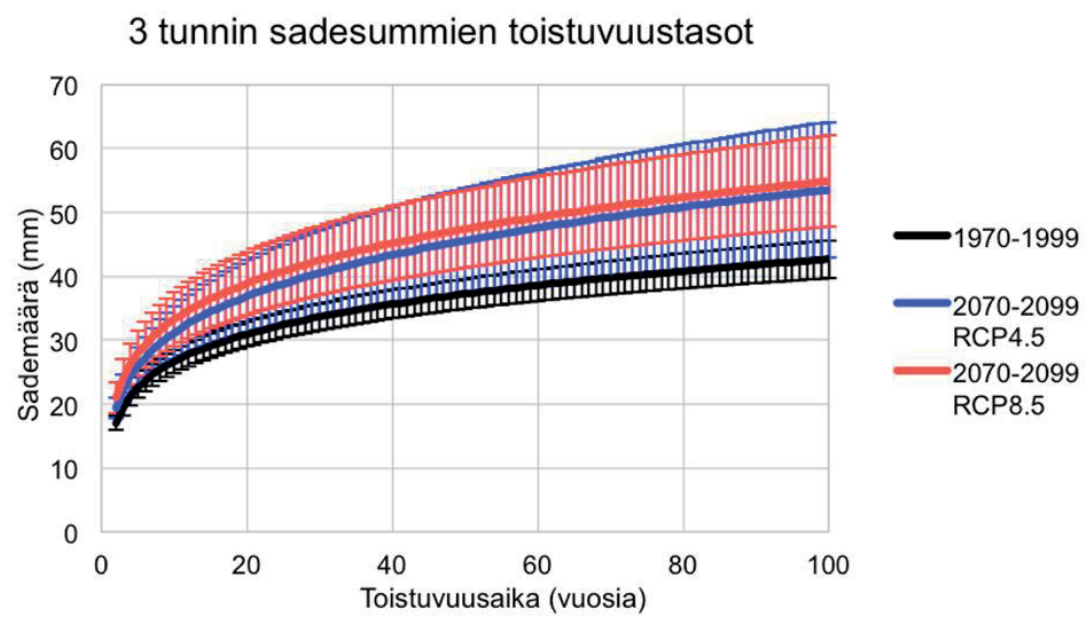

Kuva 5.1: Suurimpien kolmen tunnin sadekertymien toistuvuustasot Helsingin ympäristössä 30vuotisjaksolla 1970-1999 (musta) ja 2070-2099 (sininen; RCP4.5-skenaario ja punainen; RCP8.5-skenaario). Yhtenäiset käyrät kuvaavat mallitulosten keskiarvoa ja mallitulosten keskihajonta on esitetty pylväillä. (Mäkelä ym., 2016).

Eri säämuuttujien ääriarvojen muutosarvioissa on epävarmuuksia pääpiirteissään kahdesta syystä. Ensinnäkin, jotakin ilmiöitä, kuten esimerkiksi rajuilmoja on mahdotonta simuloida suoraan ilmastomalleilla. Lisäksi joistakin ilmiöistä me emme ole edes varmoja, lisääkö vai vähentääkö ilmastonmuutos niiden esiintymistä. Voidaan kuitenkin todeta, että Suomessa lämpötilaan ja sateeseen liittyvien ääri-ilmiöiden tulevaisuuden muutosarviot ovat kvalitatiivisesti varsin luotettavia, jos asiaa arvioidaan eri ilmastomallien tuottaman yksimielisyyden perusteella: korkeat lämpötilat yleistyvät, alhaiset lämpötilat harvinaistuvat, vuotuiset sademäärät kasvavat, ja rankkasateet yleistyvät ja voimistuvat.

\section{2 Ääriarvoanalyysin tuloksia}

Keskimääräisten sääolojen lisäksi tutkimuksessa tarkasteltiin rakennetun ympäristön kannalta merkityksellisiä sään ääri-ilmiöitä (korkea ja alhainen lämpötila, sademäärä, tuulen nopeus) sovittamalla yleinen ääriarvojakauma (GEV) 30-vuotisten tunnittaisten sääaineistojen vuotuisiin maksimiarvoihin (liite 6). Niissä mahdollisesti esiintyneet tilastollisesti merkitsevät ajalliset trendit poistettiin (Vantaalla sademäärät, Sodankylässä tuulen nopeus). Tiettyä toistuvuusaikaa $(2,5,10,20,50$ ja 100 vuotta) ja siten tiettyä vuotuista todennäköisyyttä $(50,20,10,5,2$ ja $1 \%$ ) vastaavan toistuvuustason parhaan arvion lisäksi määritettiin sen $95 \%$ :n luottamusvälin ala- ja ylärajat. Esimerkkejä tuloksista, joita aineistosta voi tuottaa, on esitetty kuvissa 5.2-5.3. 

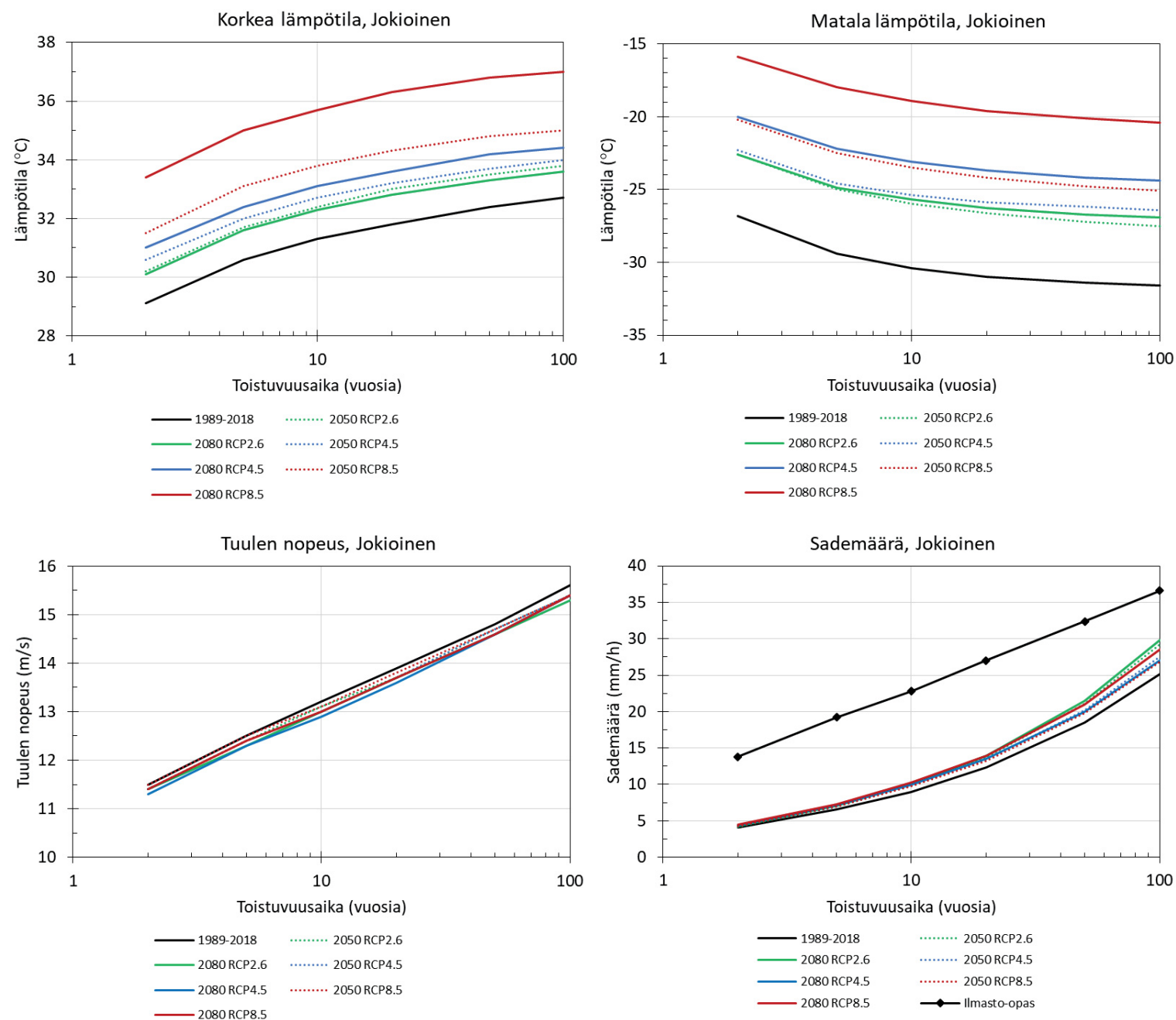

Kuva 5.2: 2-100 vuoden toistuvuusaikaa vastaavat korkean ja matalan lämpötilan, tuulen nopeuden ja yhden tunnin aikana saatavan sademäärän toistuvuustasot Jokioisissa arvioituina jakson 1989-2018 tunnittaisten säätietojen perusteella sekä niitä vastaavat tulevaisuuden arviot vuosien 2050 ja 2080 ilmastossa kolmen eri kasvihuonekaasuskenaarion perusteella (RCP2.6, RCP4.5 ja RCP8.5). Huomaa, että kyseessä ovat ns. keskiarviot (vrt. kuva 5.3) ja että vuotuinen todennäköisyys sille, että arvo ylittyy (matalalle lämpötilalle alittuu), on kääntäen verrannollinen toistuvuusaikaan. Vertailun vuoksi tuntisateiden diagrammiin on piirretty myös Ilmasto-oppaan (2020) mukaiset tuntisateiden toistuvuusaika-arviot.

Kuvasta 5.2 ilmenee, että ilmastonmuutos lisää huomattavasti korkeiden ja vähentää matalien lämpötilojen esiintymisen todennäköisyyksiä. Esimerkiksi Jokioisten v. 1989-2018 havaintojen perusteella keskimäärin kerran 10 vuodessa ylittyvä 31.3 asteen lämpötila saavutetaan vuoden 2050 ilmastossa jo keskimäärin noin joka kolmas vuosi tai useamminkin, jos kasvihuonekaasujen päästöjen kasvua ei saada taittumaan. Vastaavasti viime vuosikymmeninä keskimäärin joka toinen vuosi alittunut noin -27 asteen lämpötila kävisi jo vuosisadan puoliväliin mennessä kuvassa 5.2 esitettyjen ns. keskiarvioiden mukaan hyvin poikkeukselliseksi. Tuulen nopeudet ja tuntisademäärät kasvavat puolestaan hyvin nopeasti toistuvuusajan funktiona, mutta ilmastonmuutoksen vaikutus niihin on pienempi kuin lämpötilan ääri-ilmiöihin. 
Koska tuntisateet on arvioitu hyvin karkeasti, tasoittuu suurin osa voimakkaista tuntisateista aineistosta pois ja arvioidut tuntisateiden toistuvuustasot jäävät huomattavan mataliksi. Lisäksi tarkastelujakson lyhyys heikentää etenkin sademäärien ääriarvoanalyysin tarkkuutta. Tämän takia kuvaan 5.2 on piirretty myös ajallisesti ja alueellisesti laajempiin tutkimusaineistoihin perustuvat tuntisateiden toistuvuusaika-arviot (Saku ym., 2016). Kuvasta nähdään, että tässä työssä saadut tuntisateiden toistuvuustasot ovat selkeästi aliarvioita.

Toisin kuin tässä raportissa, ääriarvoanalyysejä tehtäessä käytetään yleensä mahdollisimman pitkiä havaintoaikasarjoja (esim. Venäläinen ym. 2007, 2009; Aaltonen ym., 2008; Kilpeläinen ym. 2008; Saku ym., 2012, 2016; Laapas ym., 2017). Nyt käytetyn havaintojakson lyhyys toistuvuusaika-arvioiden kannalta ilmenee siten, että tulosten $95 \%$ :n luottamusvälit ovat varsin leveitä (kuva 5.3). Erityisen epävarmoja ovat tunnissa kertyvien sademäärien toistuvuusarviot, mikä on tärkeää pitää mielessä (kuva 5.2). Toisaalta tässä työssä tuotettujen tunnittaisten säätietojen avulla voidaan tutkia ilmastonmuutoksen vaikutuksia esimerkiksi sellaisten säätilojen esiintymiseen ja kestoon, joissa kaksi tai useampi säätekijä voivat yhdessä aiheuttaa ongelmia rakennuksissa, esimerkiksi huonontaa lämpöviihtyvyyttä tai tuottaa kosteusvaurioita.

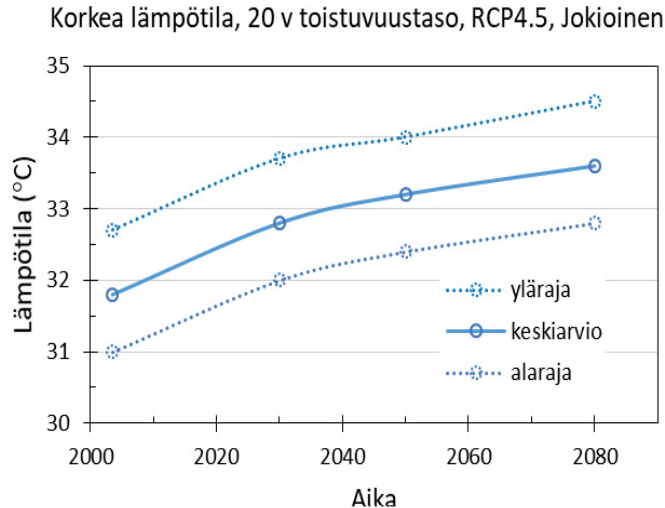

Sademäärä, 20 v toistuvuustaso, RCP4.5, Jokioinen

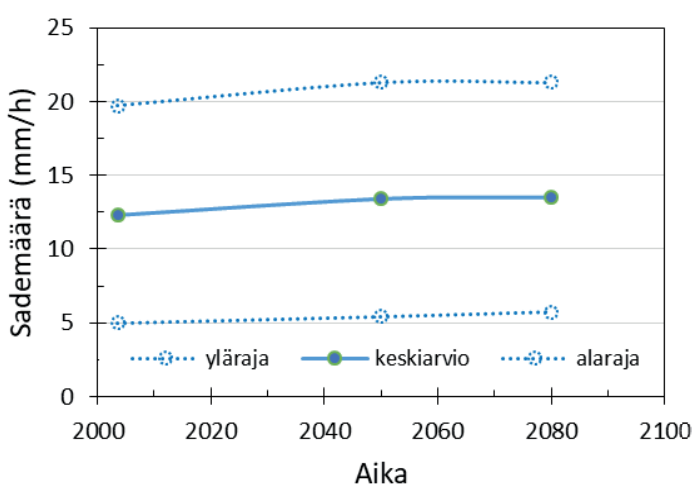

Matala lämpötila,20 v toistuvuustaso, RCP4.5, Jokioinen

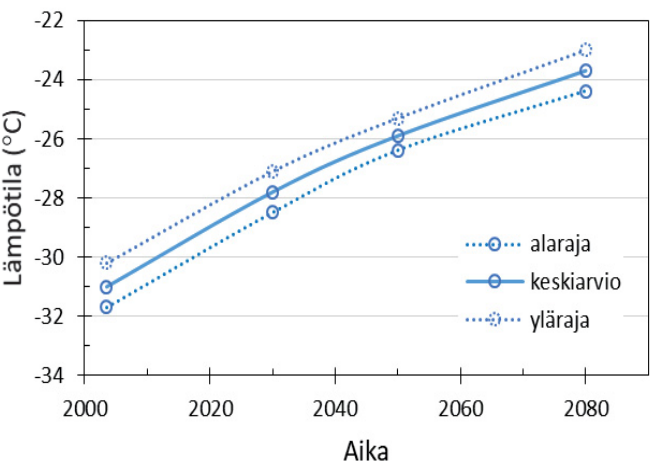

Tuulen nopeus, $20 \mathrm{v}$ toistuvuustaso, RCP4.5, Jokioinen

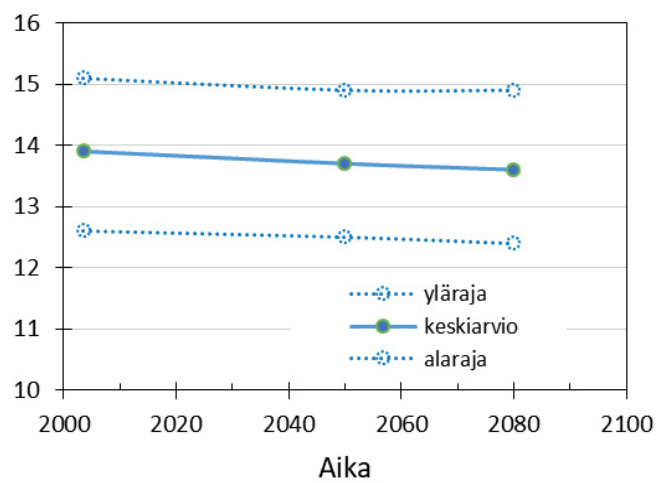

Kuva 5.3: 20 vuoden toistuvuusaikaa vastaavat korkean ja matalan lämpötilan, tuulen nopeuden ja yhden tunnin sademäärän toistuvuustasot epävarmuusväleineen Jokioisissa arvioituina jakson 1989-2018 tunnittaisten säätietojen perusteella sekä niitä vastaavat tulevaisuuden arviot vuosien 2050 ja 2080 ilmastossa RCP4.5-kasvihuonekaasuskenaarion toteutuessa (RCP2.6, RCP4.5 ja RCP8.5). 


\subsection{Lämmitysjärjestelmien mitoittavat ulkolämpötilat}

Kuten edellisessä luvussa todettiin, 30 vuoden jakso on varsin lyhyt harvinaisten ja etenkin poikkeuksellisten sääolojen esiintymistä koskevien selvitysten kannalta. Rakennusten lämmitysjärjestelmien lämmitystehon mitoittavia ulkolämpötiloja määritettäessä seurattiin vuonna 1966 käytettyä, sittemmin myös Jylhän ym. (2011) kuvaamaa menetelmää, jossa tarkastelujakson pituus on 60 vuotta. Tutkittavina olivat vuoden toiseksi alimmat kahden vuorokauden keskilämpötilat vuosina 1959-2018. Näihin ns. mitoituslämpötiloihin vaikuttaa suuresti kaksi poikkeuksellisen kylmää jaksoa, joista ensimmäinen sattui tammikuussa 1987 vyöhykkeillä I-III ja jälkimmäinen tammikuussa 1999 vyöhykkeellä IV (kuva 5.4). Kyseisten kovien pakkasjaksojen vuoksi vuoden toiseksi kylmimpien päivien aikasarjat (kuva 5.4) eivät osoita niin selvää lauhtumista vuosikymmenien kuluessa, että pitkäaikaiset trendit olisivat tilastollisesti merkitseviä. Ainoastaan Sodankylässä trendin merkitsevyyttä osoittava $p$-arvo on 0.05, ja kuvaan onkin piirretty sitä vastaava trendisuora.
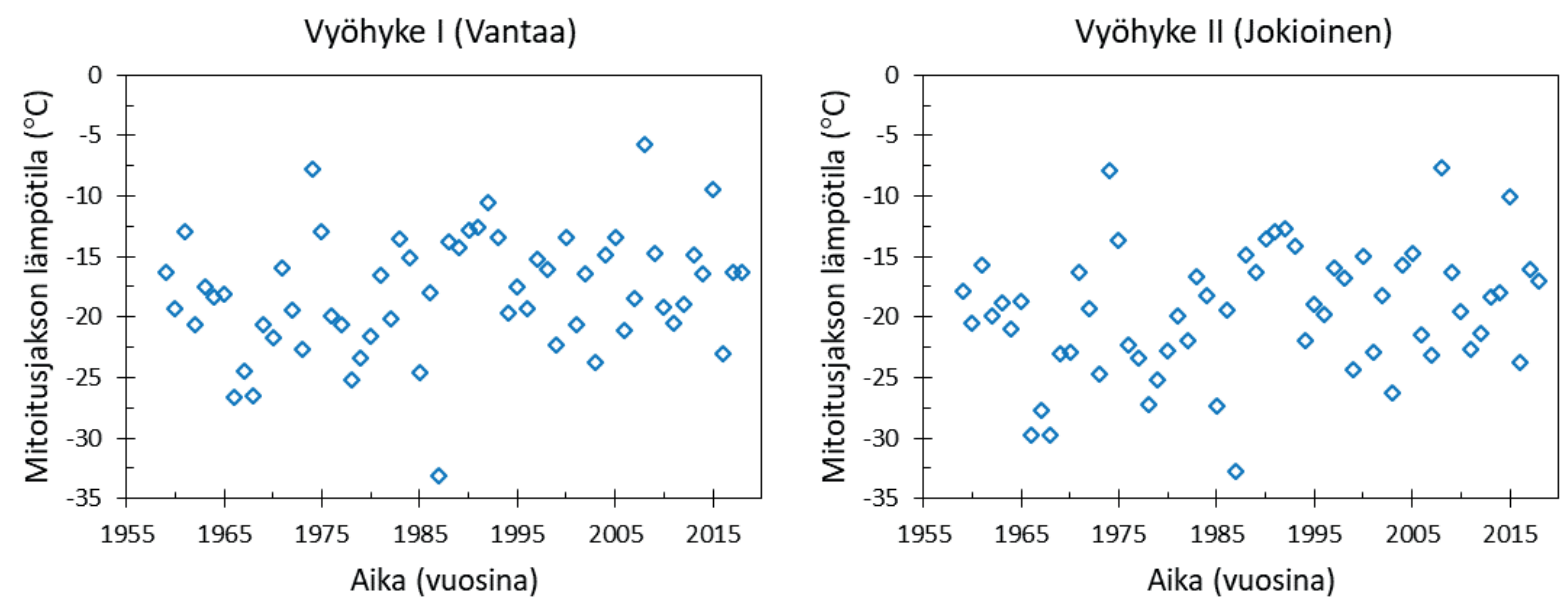

Vyöhyke III (Jyväskylä)
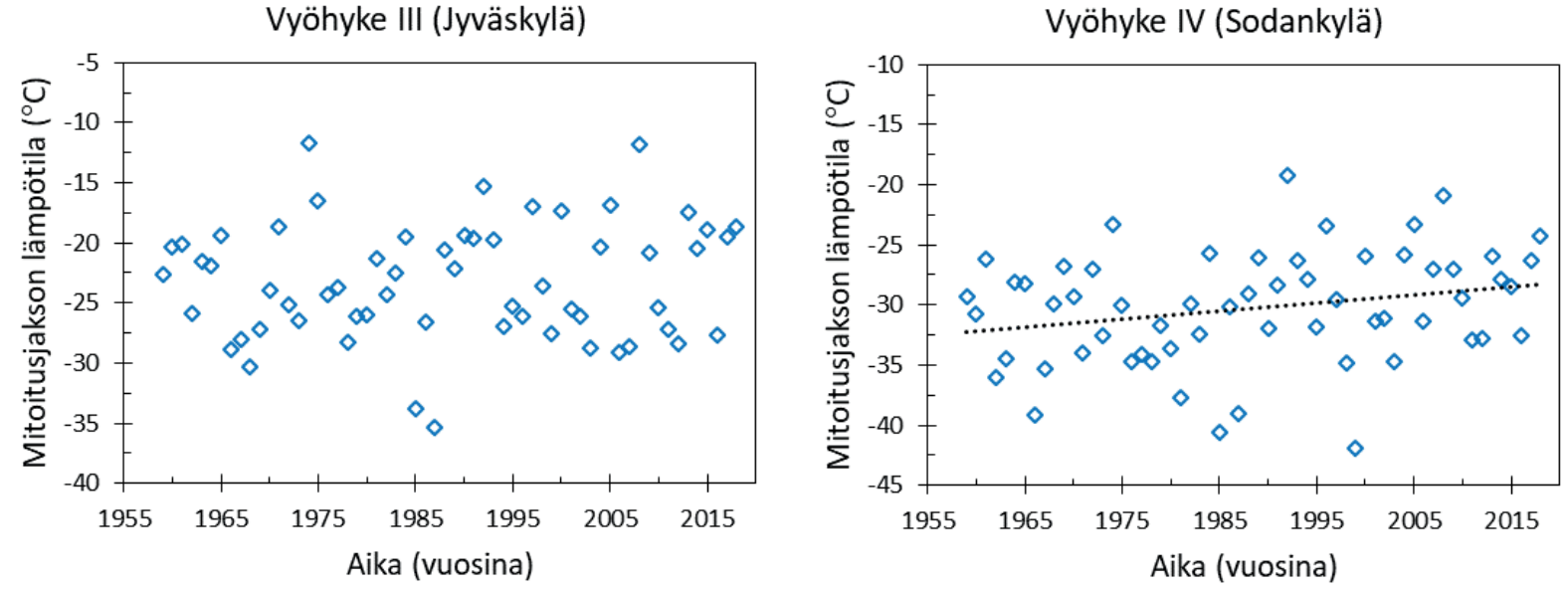

Kuva 5.4: Kunkin vuoden toiseksi kylmimmän kahden vuorokauden pituisen pakkasjakson keskilämpötila Vantaalla, Jokioisissa, Jyväskylässä ja Sodankylässä v. 1959-2018. Mitoituslämpötilat on määritetty näiden perusteella. Sodankylän aikasarjaan sovitettu lineaarinen trendi on jokseenkin tilastollisesti merkitsevä $(p=0.05)$. 
Mitoittavana ulkoilman lämpötilana pidetään matalinta arvoa, jonka vuoden toiseksi alimmat kahden vuorokauden keskilämpötilat ovat saavuttaneet 60 vuoden aikana. Taulukon 5.1 oikeassa sarakkeessa on esitetty jakson 1959-2018 perusteella määritetyt mitoittavat ulkolämpötilat eri vyöhykkeillä I-IV. Keskimmäisessä sarakkeessa on puolestaan voimassa olevat mitoittavat ulkoilman lämpötilat, jotka on alun perin määritetty vuonna 1966 (LVTY, 1966). Nähdään, että voimassa olevat arvot ovat korkeampia, joten niitä ei ole tarvetta vielä nostaa.

Taulukon 5.1 keskimmäisessä sarakkeessa on esitetty voimassa olevat mitoittavat ulkoilman lämpötilat eri vyöhykkeillä I-IV ja oikeassa sarakkeessa jakson 1959-2018 perusteella määritetyt mitoituslämpötilat. Nähdään, että voimassa olevat arvot ovat korkeampia, joten niitä ei ole tarvetta vielä nostaa.

Taulukko 5.1: Lämmitysjärjestelmien lämmitystehon mitoituksessa käytettävä ulkoilman lämpötila nykyisten rakentamismääräysten mukaan (YMa 1010/2017*) sekä vastaava mitoituslämpötila Vantaalla, Jokioisissa, Jyväskylässä ja Sodankylässä vuosina 1959-2018 tehtyihin lämpötilamittauksiin perustuen.

\begin{tabular}{lcc}
\hline Vyöhyke & \multicolumn{2}{c}{ Mitoittava ulkoilman lämpötila $\left({ }^{\circ} \mathrm{C}\right)$} \\
& YMa 1010/2017 & 1959-2018 \\
\hline I (Vantaa) & -26 & -33.1 \\
II (Jokioinen) & -29 & -32.8 \\
III (Jyväskylä) & -32 & -35.4 \\
IV (Sodankylä) & -38 & -41.9 \\
\hline
\end{tabular}

* Ympäristöministeriön asetus uuden rakennuksen energiatehokkuudesta (1010/2017). 


\section{Yhteenveto}

Tutkimuksessa tarkasteltiin sääoloja sekä rakennuksien kokeman kosteusrasituksen että lämmitys- ja jäähdytysenergian tarpeen kannalta. Tarkasteluja varten koottiin 30 vuoden säähavainnot aikajaksolta 1989-2018 ja muodostettiin niistä tunnittaiset aikasarjat. Ilmastomallitulosten perusteella laadittiin 30-vuotiset sääaineistot myös jaksoille 2015-2046 (lähitulevaisuutta kuvaava ilmasto), 2035-2064 (kuluvan vuosisadan puoliväliä kuvaava ilmasto) ja 2065-2094 (kuluvan vuosisadan loppupuolen ilmasto); kyseiset ilmastolliset jaksot on nimetty keskikohtiensa eli vuosien 2030, 2050 ja 2080 mukaan. Rakennusten energialaskentaa varten muodostettiin ns. ilmastolliset testivuodet edellä mainituille jaksoille. Lämpötilojen aikasarjoja parannettiin ottamalla huomioon vuorokauden ylintä ja alinta lämpötila koskevat mittaukset, joita ei aiemmin vastaavissa tutkimuksessa ole käytetty.

Hankkeessa tuotettuja 30-vuotisia tunnittaisia sääaineistoja voidaan jatkossa käyttää esimerkiksi rakennusfysikaalisten testivuosien päivittämiseen. Rakennusfysikaalisia tarkasteluja varten koottiin myös erillinen vertailuvuosi, joka koostuu Jokioisissa vuonna 2015 tunnin välein tehdyistä säähavainnoista, ja arvioitiin ilmastonmuutoksen vaikutuksia kyseisiin sääoloihin. Erikseen laaditun Jokioisten vuoden 2015 sääaineiston soveltuvuutta erilaisiin rakennusfysikaalisiin tarkasteluihin ei ole testattu, mutta se sopinee niihin paremmin kuin likimääräisemmin laaditut aikasarjat vuodelle 2015 Jokioisten 30-vuotisaineistossa.

Uusi energialaskennan testivuosi (TRY2020) koostuu suurelta osin uusista tyyppikuukausista (vyöhykkeestä riippuen 7-11 uutta kuukautta). Uusi testivuosi on $0.17-0.36{ }^{\circ} \mathrm{C}$ lämpimämpi kuin TRY2012, vaikka joinakin yksittäisinä kuukausina se onkin viileämpi.

Rakennusten lämmitysjärjestelmien mitoituslämpötiloja koskevassa työosuudessa seurattiin vuosina 1966 ja 2011 käytettyä menetelmää. Tulosten perusteella lämmitysjärjestelmiä mitoittavia ulkolämpötiloja ei ole tarvetta vielä nostaa.

Tässä työssä energialaskennan testivuoden lopullisiin valintoihin vaikuttivat eri sääsuureiden painotettujen tilastollisten jakaumien lisäksi niiden aritmeettiset kuukausikeskiarvot ja keskihajonnat sekä pyrkimys välttää liian suuria keinotekoisia säätilojen muutoksia kuukausien vaihteessa. Lisäksi kuukausia toisiinsa liitettäessä tarvittavien tasoitusten tekotapaa kehitettiin aiempaan verrattuna.

Myös tuntisateiden 30-vuotisaikasarjan muodostamistapaa on kehitetty. Tehtyjen vertailujen perusteella voidaan ensinnäkin sanoa, että laadittujen tuntisateiden aikasarjojen tilastolliset ominaisuudet koskien poudan ja sateen yleisyyttä ja sateiden voimakkuutta eivät muuttuneet oleellisesti huolimatta mittausten automatisoinnista kesken 30-vuotisjakson. Toiseksi voitiin todeta, että sademittaukset ja käytetty arviointimenetelmä olivat yhtä mieltä poudan tai sateen sattumisesta 90 prosentissa tapauksista vertailuvuotena 2015, vaikkakin yksittäistapauksissa arviot ja suorat tuntimittaukset saattoivat poiketa toisistaan paljonkin. Kaiken kaikkiaan menetelmät kuitenkin aliarvioivat täysin sateettoman sään osuutta. Toisaalta työssä saadut tuntisateiden toistuvuustasot ovat selkeästi aliarvioita.

On tärkeää ymmärtää, että tuleva ilmastonmuutos riippuu ratkaisevasti kasvihuonekaasujen päästöistä. Jos tavoite rajoittaa maapallon keskilämpötilan nousu kahteen asteeseen teollistumista edeltävään aikaan verrattuna toteutuu, muutos jäisi jonkin verran RCP4.5skenaariota pienemmäksi mutta olisi selvästi voimakkaampi kuin mitä RCP2.6-skenaario ennustaa. Kunnianhimoinen ilmastopolitiikka saattaisi viedä muutoksen lähelle RCP2.6- 
skenaariota. Pyrittäessä arvioimaan ilmastonmuutoksen vaikutuksia ja mahdollisuuksia sopeutua muutokseen voitaneen siis ensisijaisesti keskittyä näihin kahteen skenaarioon. RCP8.5-skenaario puolestaan kuvaa sellaista kehitystä, jossa pyrkimykset ilmastonmuutoksen rajoittamiseen lyödään käytännössä täysin laimin. Tällainen tulevaisuudenkuva ei onneksi vaikuta tällä hetkellä ainakaan pitkällä tähtäimellä todennäköiseltä.

Lisää epävarmuutta ilmastonmuutosarvioihin aiheutuu ilmastomallien tulosten eroista. Eri mallit tuottavat melko selvästi toisistaan poikkeavia arvioita, vaikka niitä ajettaessa käytettäisiin samoja kasvihuonekaasuskenaarioita. Tässä selvityksessä on tulevaisuuden sääaikasarjoja laadittaessa johdonmukaisesti käytetty lähtökohtana mallitulosten keskiarvoa, mutta ei ole mitenkään varmaa, että juuri tämä kuvaa tulevaa kehitystä parhaiten.

Keskimääräisten sääolojen lisäksi tutkimuksessa on tarkasteltu rakennetun ympäristön kannalta merkityksellisiä sään ääri-ilmiöitä (korkea ja matala lämpötila, sademäärä, tuulen nopeus). Aiempien tutkimusten mukaisesti saatiin tulokseksi, että ilmastonmuutos lisää huomattavasti korkeiden ja vähentää matalien lämpötilojen esiintymisen todennäköisyyksiä. Tuulen nopeuksiin ja yksittäisen tunnin aikana kertyneisiin sademääriin ilmastonmuutos vaikuttaa vähemmän kuin lämpötiloihin. Työssä tuotettujen tunnittaisten säätietojen avulla voidaan tehdä jatkotutkimuksia esimerkiksi siitä, miten tulevaisuudessa muuttuvat sellaisten säätilojen esiintyminen ja kesto, joissa kaksi tai useampi säätekijä voivat yhdessä aiheuttaa rakennuksille ongelmia. 


\section{Kirjallisuus}

Aalto, J., Pirinen, P., and Jylhä, K., 2016: New gridded daily climatology of Finland permutation-based uncertainty estimates and temporal trends in climate. J. Geophys. Res. Atmos., 121, doi:10.1002/2015JD024651

Aaltonen, J., H. Hohti, K. Jylhä, T. Karvonen, T. Kilpeläinen, J. Koistinen, J. Kotro, T. Kuitunen, M. Ollila, A. Parvio, S. Pulkkinen, J. Silander, T. Tiihonen, H. Tuomenvirta ja A. Vajda, 2008: Rankkasateet ja taajamatulvat (RATU). Suomen ympäristö 31-2008.

Böök, H., Poikonen, A., Aarva, A., Mielonen, T., Pitkänen, M.R.A., Lindfors, A.V., 2020: Photovoltaic system modeling: A validation study at high latitudes with implementation of a novel DNI quality control method. Solar Energy 204, 316-329.

https://doi.org/10.1016/j.solener.2020.04.068

Gilleland, E., and Katz, R.W, 2016: extRemes 2.0: An Extreme Value Analysis Package in R. Journal of Statistical Software, 72(8), 1-39. doi:10.18637/jss.v072.i08

Global Carbon Project, 2019: Supplemental data of Global Carbon Budget 2019 (Version 1.0) [Data set]. Global Carbon Project. https://doi.org/10.18160/gcp-2019

Ilmasto-opas, 2020: Lyhytkestoisten sateiden rankkuus ja toistuvuusaika Suomessa. https://ilmasto-opas.fi/oppimismoduulit/rankkasateiden-toistuvuus/ (4.11.2020)

IPCC, 2013: Annex II: Climate System Scenario Tables [Prather, M., G. Flato, P. Friedlingstein, C. Jones, J.-F. Lamarque, H. Liao and P. Rasch (eds.)]. In: Climate Change 2013: The Physical Science Basis. Contribution of Working Group I to the Fifth Assessment Report of the Intergovernmental Panel on Climate Change [Stocker, T.F., D. Qin, G.-K. Plattner, M. Tignor, S.K. Allen, J. Boschung, A. Nauels, Y. Xia, V. Bex and P.M. Midgley (eds.)]. Cambridge University Press, Cambridge, United Kingdom and New York, NY, USA.

Jylhä, K., Kalamees, T., Tietäväinen, H., Ruosteenoja. K., Jokisalo, J., Hyvönen, R., Ilomets, S., Saku, S., and Hutila, A., 2011: Rakennusten energialaskennan testivuosi TRY2012 ja arviot ilmastonmuutoksen vaikutuksista. (Test reference year 2012 for building energy demand and impacts of climate change). Finnish Meteorological Institute, Reports, 2011:6, 110 p. https://helda.helsinki.fi/handle/10138/33069

Jylhä K., J. Jokisalo, K. Ruosteenoja, K. Pilli-Sihvola, T. Kalamees, T. Seitola, H. Mäkelä, R. Hyvönen, M. Laapas and A. Drebs, 2015a: Energy demand for the heating and cooling of residential houses in Finland in a changing climate. Energy and Buildings, 99, 104-116, doi:10.1016/j.enbuild.2015.04.001

Jylhä K., K. Ruosteenoja, J. Jokisalo, K. Pilli-Sihvola, T. Kalamees, H. Mäkelä, R. Hyvönen, and A. Drebs, 2015b: Hourly test reference weather data in the changing climate of Finland for building energy simulations. Data in Brief, 4, 162-169. doi:10.1016/j.dib.2015.04.026

Jylhä, K., Fortelius, C., Saranko, O., Ruosteenoja, K., Di Sabatino, S., and Brattich, E., 2019: Detailed report on local meteorological conditions. Deliverable 6.4 for the EU H2020 iSCAPE project under Grant Agreement No 689954. https://www.iscapeproject.eu/wpcontent/uploads/2019/11/iSCAPE_D6.4_Detailed-report-on-local-meteorologicalconditions.pdf

Kalamees T., Jylhä K., Tietäväinen H., Jokisalo J., Ilomets S., Hyvönen R., Saku S., 2012: Development of weighting factors for climate variables for selecting the energy reference year 
according to the EN ISO 15927-4 standard. Energy and Buildings, 47, 53-60. doi:10.1016/j.enbuild.2011.11.031

Karlsson, K.-G., Anttila, K., Trentmann, J., Stengel, M., Fokke Meirink, J., Devasthale, A., Hanschmann, T., Kothe, S., Jääskeläinen, E., Sedlar, J., Benas, N., van Zadelhoff, G.-J., Schlundt, C., Stein, D., Finkensieper, S., Håkansson, N., Hollmann, R., 2017a: CLARA-A2: the second edition of the CM SAF cloud and radiation data record from 34 years of global AVHRR data, Atmospheric Chemistry and Physics 17, 5809-5828. https://doi.org/10.5194/acp-17-5809-2017

Karlsson, K.-G., Anttila, K., Trentmann, J., Stengel, M., Fokke Meirink, J., Devasthale, A., Hanschmann, T., Kothe, S., Jääskeläinen, E., Sedlar, J., Benas, N., van Zadelhoff, G.-J., Schlundt, C., Stein, D., Finkensieper, S., Håkansson, N., Hollmann, R., Fuchs, P., Werscheck, M., 2017b: CLARA-A2: CM SAF cLoud, Albedo and surface RAdiation dataset from AVHRR data - Edition 2, Satellite Application Facility on Climate Monitoring. https://doi.org/10.5676/EUM_SAF_CM/CLARA_AVHRR/V002

Kilpeläinen, T., Tuomenvirta, H., and Jylhä, K. 2008: Climatological characteristics of summer precipitation in Helsinki during the period 1951-2000. Boreal Env. Res. 13: 67-80.

Laapas, M. and Venäläinen, A., 2017: Homogenization and trend analysis of monthly mean and maximum wind speed time series in Finland, 1959-2015. Int. J. Climatol, 37: 4803-4813. doi:10.1002/joc.5124

Lehtonen, I., 2011: Äärisademäärien muutokset Euroopassa maailmanlaajuisten ilmastomallien perusteella. Pro gradu -tutkielma, Helsingin yliopiston Fysikaalisten tieteiden laitos. 70 s. http://urn.fi/URN:NBN:fi-fe201109052340

Lehtonen, I., Ruosteenoja, K., and Jylhä, K., 2014a: Projected changes in European extreme precipitation indices on the basis of global and regional climate model ensembles. International Journal of Climatology, 34, 1208-1222, doi:10.1002/joc.3758

Lehtonen, I., Ruosteenoja, K., Venäläinen, A., and Gregow, H., 2014b: The projected 21st century forest-fire risk in Finland under different greenhouse gas scenarios. Boreal Environment Research, 19, 127-139. https://helda.helsinki.fi/bitstream/handle/10138/228540/ber19-2-127.pdf?sequence=1

Lehtonen, I., Venäläinen, A., Kämäräinen, M., Peltola, H., and Gregow, H., 2016a: Risk of large-scale fires in boreal forests of Finland under changing climate, Nat. Hazards Earth Syst. Sci., 16, 239-253, https://doi.org/10.5194/nhess-16-239-2016.

Lehtonen, I., Kämäräinen, M., Gregow, H., Venäläinen, A., and Peltola, H., 2016b: Heavy snow loads in Finnish forests respond regionally asymmetrically to projected climate change, Nat. Hazards Earth Syst. Sci., 16, 2259-2271, https://doi.org/10.5194/nhess-16-2259-2016.

Lehtonen, I., Ruosteenoja, K., Mäkelä, A., 2019a: Suomen muuttuva ilmasto - tietoa sähkönsiirtojärjestelmän riskien arviointia varten. Ilmatieteen laitos, Raportteja 2019:2, 34 s. https://helda.helsinki.fi/handle/10138/301521

Lehtonen, I., Venäläinen, A., Kämäräinen, M., Asikainen, A., Laitila, J., Anttila, P., and Peltola, H., 2019b: Projected decrease in wintertime bearing capacity on different forest and soil types in Finland under a warming climate, Hydrol. Earth Syst. Sci., 23, 1611-1631. https://doi.org/10.5194/hess-23-1611-2019, https://doi.org/10.5194/hess-23-1611-2019supplement 
Lehtonen, I., Venäläinen, A., Gregow, H., 2020: Ilmastonmuutoksen vaikutukset Suomessa metsänhoidon näkökulmasta. Ilmatieteen laitos, Raportteja 2020:5, 81 s.

https://helda.helsinki.fi/handle/10138/319348

Lindfors, A. V., Kujanpää, J., Kalakoski, N., Heikkilä, A., Lakkala, K., Mielonen, T., Sneep, M., Krotkov, N. A., Arola, A., and Tamminen, J., 2018. The TROPOMI surface UV algorithm. Atmospheric Measurement Techniques 11, 997-1008. https://doi.org/10.5194/amt$11-997-2018$

LVTY, 1966: Lämmitys- ja ilmanvaihtolaitteiden suunnittelun normaaliohjeet. Lämpö- ja vesijohtoteknillinen yhdistys r.y., Helsinki.

Maxwell, E.L., 1987. A Quasi-Physical Model for Converting Hourly Global Horizontal to Direct Normal Insolation. Technical Report No. SERI/TR-215-3087, Solar Energy Research Institute (SERI).

Mikkonen, S., Laine, M., Mäkelä, H. M., Gregow, H., Tuomenvirta, H., Lahtinen, M., and Laaksonen, A., 2015: Trends in the average temperature in Finland, 1847-2013. Stochastic Environmental Research and Risk Assessment, 29(6):15211529. http://dx.doi.org/10.1007/s00477-014-0992-2

Mäkelä, A., Lehtonen, I., Ruosteenoja, K., Tuomenvirta, H., Jylhä, K., and Drebs, A., 2016: Ilmastonmuutos pääkaupunkiseudulla. Ilmatieteen laitos, Raportteja 2016:8, https://helda.helsinki.fi/handle/10138/170155

Perez, R., Ineichen, P., Seals, R., Michalsky, J., and Stewart, R., 1990. Modeling daylight availability and irradiance components from direct and global irradiance. Solar Energy 44, 271-289. https://doi.org/10.1016/0038-092X(90)90055-H

Pilli-Sihvola, K., Haavisto, R., Leijala, U., Luhtala, S., Mäkelä, A., Ruuhela, R., and Votsis, A., 2018: Sään ja ilmastonmuutoksen aiheuttamat riskit Helsingissä. Helsingin kaupungin kaupunkiympäristön julkaisuja 2018:6. $92 \mathrm{~s}$.

https://www.hel.fi/static/liitteet/kaupunkiymparisto/julkaisut/julkaisut/julkaisu-06-18.pdf

Riihelä, A., Manninen, T., Laine, V., Andersson, K., and Kaspar, F., 2013: CLARA-SAL: a global 28 yr timeseries of Earth's black-sky surface albedo, Atmospheric Chemistry and Physics 13, 3743-3762. https://doi.org/10.5194/acp-13-3743-2013

Rossi V., 1975: The shadowing-ring correction for sky radiation pyranometers, Ilmatieteen laitoksen toimituksia No 82, Helsinki.

Ruosteenoja, K., Jylhä, K., Mäkelä, H., Hyvönen, R., Pirinen, P., and Lehtonen, I., 2013: Rakennusfysiikan testivuosien sääaineistot havaitussa ja arvioidussa tulevaisuuden ilmastossa - REFI-B -hankkeen tuloksia. Ilmatieteen laitos, Raportteja 2013:1. 48 s. (In Finnish with abstract in English and Swedish). https://helda.helsinki.fi/handle/10138/38648

Ruosteenoja, K., Jylhä, K., and Kämäräinen, M., 2016: Climate projections for Finland under the RCP forcing scenarios. Geophysica, 51, 17-50.

http://www.geophysica.fi/pdf/geophysica_2016_51_1-2_017_ruosteenoja.pdf

Ruosteenoja, K., Jylhä, K., Räisänen, J. and Mäkelä, A., 2017: Surface air relative humidities spuriously exceeding $100 \%$ in CMIP5 model output and their impact on future projections. J. Geophys. Res. Atmos., 122, 9557-9568. DOI:10.1002/2017JD026909. 
Ruosteenoja, K., Vihma, T., and Venäläinen, A., 2019: Projected changes in European and North Atlantic seasonal wind climate. derived from CMIP5 simulations. Journal of Climate, 32, 6467-6490. DOI: 10.1175/JCLI-D-19-0023.1

Räihä, J., 2018: Pitkittyneet kuivuus-, sade- ja hellejaksot Suomen muuttuvassa ilmastossa. Pro gradu -tutkielma, Helsingin yliopisto, Matemaattis-luonnontieteellinen tiedekunta. $51+2 \mathrm{~s}$. http://urn.fi/URN:NBN:fi-fe201804208669

Räty, O., Räisänen, J. and Ylhäisi, J. S., 2014: Evaluation of delta change and bias correction methods for future daily precipitation: intermodel cross-validation using ENSEMBLES simulations. Climate Dynamics 42.9, 2287-2303.

Saku, S., Solantie, R., Jylhä, K., Venäläinen, A., Valta, H., 2012: Äärilämpötilojen alueellinen vaihtelu Suomessa. Ilmatieteen laitos, Raportteja. 2011:1, 92 p. (In Finnish with abstract in English) http://hdl.handle.net/10138/29511

Saku, S., Mäkelä, A., Jylhä, K., Niinimäki, N., 2016: Lyhytkestoisten sateiden rankkuus ja toistuvuusaika Suomessa. Ilmatieteen laitos, 15 s., http://bit.ly/2eyTzjZ

SFS EN ISO 15927-4, 2005: Hygrothermal performance of buildings - Calculation and presentation of climatic data - Part 4: Data for assessing the annual energy for heating and cooling. (Rakennusten lämpö- ja kosteustekninen käyttäytyminen. Säätietojen laskenta ja esittäminen. Osa 4: Tuntitiedot lämmityksen ja jäähdytyksen vuotuisen energiantarpeen laskentaan)

Veijalainen, N., Ruosteenoja, K., Uusikivi, J., Mäkelä, A., and Vehviläinen, B., 2018: Ilmastonmuutos ja virtaamien muuttuminen Kemi-, Kymi- ja Lieksanjoen alueilla. Suomen ympäristökeskuksen raportteja 27-2018. https://helda.helsinki.fi/handle/10138/255640

Venäläinen, A., Saku, S., Kilpeläinen, T., Jylhä, K., Tuomenvirta, H., Vajda, A., Ruosteenoja, K. and Räisänen, J., 2007. Sään ääri-ilmiöistä Suomessa. Ilmatieteen laitos, Raportteja 2007: 4, 81. http://hdl.handle.net/10138/1138

Venäläinen, A., Jylhä, K., Kilpeläinen, T., Saku, S., Tuomenvirta, H., Vajda, A., Ruosteenoja, K., 2009: Recurrence of heavy precipitation, dry spells and deep snow cover in Finland based on observations. Boreal Env. Res., 14: 166-172. http://hdl.handle.net/10138/233283

Venäläinen, A., Ruosteenoja, K., and Lehtonen, I., 2019: Projections of future climate for Europe, Uruguay and China with implications on forestry. Ilmatieteen laitos, Raportteja 2019:3, https://doi.org/10.35614/isbn.9789523360853

Vinha, J., Laukkarinen, A., Mäkitalo, M., Nurmi, S., Huttunen, P., Pakkanen, T., Kero, P., Manelius, E., Lahdensivu, J., Köliö, A., Lähdesmäki, K., Piironen, J., Kuhno, V., Pirinen, M., Aaltonen, A., ja Suonketo, J., 2013: Ilmastonmuutoksen ja lämmöneristyksen lisäyksen vaikutukset vaipparakenteiden kosteusteknisessä toiminnassa ja rakennusten energiankulutuksessa. Tutkimusraportti 159. Tampereen teknillinen yliopisto. Rakennustekniikan laitos, http://urn.fi/URN:ISBN:978-952-15-2949-8.

YMa 1010/2017: Ympäristöministeriön asetus uuden rakennuksen energiatehokkuudesta (1010/2017). https://www.finlex.fi/fi/laki/alkup/2017/20171010

YMa 1010/2017, Liite 1: E-luvun laskennassa ja lämmitystehon laskennassa käytettävät säätiedot. https://www.finlex.fi/data/sdliite/liite/6800.pdf 


\section{LIITTEET:}

Liite 1. Säteilylaskenta

Liite 2. Tunnittaisten sadetietojen laadinta

Liite 3. Energialaskennan testivuosien valinta ja lisävertailuja

Liite 4. Eri ilmastosuureitten muuntaminen kuvaamaan tulevaisuuden ilmastoa

Liite 5. Ilmastosuureitten kuukausikeskiarvojen muutokset 30-vuotisista aikasarjatiedostoista

Liite 6. Ääriarvojen laskeminen 


\section{Liite 1. Säteilylaskenta}

Säteilyaikasarjoissa ja niiden tuotantoprosessissa esiintyy joitain eroavaisuuksia verrattuna aiemmin määritettyjen rakennusten energialaskennan (TRY2012) ja rakennusfysikaalisten testivuosien säteilytietojen laatimiseen ja tuolloin muodostettuihin aikasarjoihin (Jylhä ym., 2011; Ruosteenoja ym., 2013). Aineiston eroavaisuuksia selittävät mm. viime vuosina toteutetut havaintojen operatiiviset laadunparannustoimet, tälle aineistolle varta vasten toteutettu ja dokumentoitu virhetarkastelu sekä puuttuvien havaintojen täydentämistä ja säteilylaskentaa koskevat menetelmälliset erot. Uusi aineisto on pyritty tuottamaan objektiivisuutta painottaen, hyödyntämällä läpinäkyviä ja hyväksi todettuja menetelmiä ja oheisaineistoja. Tavoitteena on lisäksi, että valitusta yhdenmukaisesta ja eksplisiittisestä lähestymistavasta voisi olla apua, jos vastaavanlaisia säteilyaineistoja laaditaan myös tulevaisuudessa.

\section{Säteilylaskennan työvaiheet}

1. Poimitaan kokonaissäteilyenergian ja hajasäteilyenergian tunnittaiset aikasarjat.

2. Tarkistetaan, että säteilyhavaintojen lukuarvot ovat $\geq 0$.

3. Siirrytään säteilyenergioista vastaaviin säteilytehoihin (GHI ja DHI), joten muutetaan yksiköt $\mathrm{kJ} / \mathrm{m}^{2} \rightarrow \mathrm{W} / \mathrm{m}^{2}$.

4. Tarkistetaan, että DHI $\leq$ GHI.

5. Lasketaan auringon suuntakulmat ja muut tarvittavat apumuuttujat aikasarjan luontia varten (tuntihavainnon keskikohtaan).

6. Poistetaan pidemmät yksittäiset epäilyttävät DHI-jaksot (varjostusrenkaiden siirtäminen ei ole ollut ajan tasalla):

- Helsinki-Vantaan lentoasema: 1.5.2010 - 27.6.2013

- Jokioinen: 1.8.2011 - 17.5.2013

7. Poistetaan epäilyttävät havainnot seuraavin ehdoin:

- Poistetaan säteilyhavainto kun auringon korkeuskulma $<-10$ astetta.

- Poistetaan säteilyhavainto kun korkeuskulma $>10$ astetta ja säteilyä ei ole havaittu.

- Suodatetaan GHI- ja DHI -havainnot auringon korkeuskulman (x) mukaan määritetyillä dataan sovitetuilla toisen asteen yhtälöillä. Data jaetaan korkeuskulman mukaan eri luokkiin. Luokille määritetään 99. kvantiilit, jotka edustavat säteilykomponenteille sallittuja maksimiarvoja. Laskettuihin kvantiileihin lisätään alla kuvatut marginaalit ennen datan sovitusta:

- GHImaksimi $=-0.083 \mathrm{x}^{2}+21.20 \mathrm{x}+54.46$ (kvantiileihin lisätty $80 \mathrm{~W} / \mathrm{m}^{2}$ marginaali).

- DHImaksimi_vanha $=-0.079 \mathrm{x}^{2}+11.29 \mathrm{x}+51.56$ (varjostusrenkaiden ollessa käytössä, kvantiileihin lisätty $60 \mathrm{~W} / \mathrm{m}^{2}$ marginaali).

- DHImaksimi_uusi $=-0.070 \mathrm{x}^{2}+12.74 \mathrm{x}+48.10$ (varjostusrenkaiden poistuttua käytöstä, kvantiileihin lisätty $60 \mathrm{~W} / \mathrm{m}^{2}$ marginaali). 
- Auringon korkeuskulman ollessa $\leq 0$ maksimirajana käytetään sovituksen ctermiä (hajasäteilyn osalta DHImaksimi_uusi).

- Poistetaan kaikki DHI-havainnot ajankohdilta, jolloin GHI:sta ei mittausta.

8. Suoritetaan varjostusrengaskorjaus samalla menetelmällä kuin edellisessä raportissa (varjostusrenkaiden poistoajankohdat listattu menetelmän alla):

- $\Delta d=1+\frac{a \times b^{c}}{100} ; \mathrm{a}=30.98 ; \mathrm{b}=0.117 ; \mathrm{c}=$ DHI/GHI (Rossi, 1975)

- Sodankylä: 24.9.2012 12:00

- Jyväskylä: 17.10.2012 13:00

- Helsinki-Vantaa: 27.6.2013 14:00

- Jokioinen: 17.5.2013 08:00

- Korjauksen vaikutus varjostusrengasjaksoihin noin $+9-10 \%$.

9. Tarkistetaan että korjattu DHI $\leq$ GHI.

10. Lasketaan GHI:lle keskimääräinen klimatologinen koko vuoden aikasarja, jota käytetään paikkaamaan puuttuvat GHI-tuntiarvot.

11. Arvioidaan puuttuvat DHI-havainnot GHI:n avulla avulla DISC-mallia (Maxwell, 1987) hyödyntäen.

12. Tarkistetaan että laskettu DHI $\leq$ GHI.

13. Lasketaan suora säteily (DNI) GHI:n, DHI:n ja auringon korkeuskulman avulla.

14. Käytetään lasketulle DNI:1le auringon korkeuskulmasta (x) riippuvaa laaduntarkastusrajaa:

- $\mathrm{DNI}_{\mathrm{maksimi}}=-838 * \exp (-0.112 \mathrm{x})+951$ (Böök ym. 2020).

15. Muutetaan alle 5 asteen auringon korkeuskulmilla kaikki suora säteily (DNI) hajasäteilyksi (samaan tapaan kuin edellisessä raportissa).

16. Käytetään satelliittituotteesta määritettyä kuukausikohtaista maan pinnan albedon aikasarjaa (Karlsson ym., 2017a, b; Riihelä ym., 2013). Puuttuville kuukausille käytetään kuukausiaikasarjasta laskettuja klimatologisia keskiarvoja. Mikäli yhtäkään lukuarvoa kyseiselle kuukaudelle ei ole saatavissa (talvikuukaudet), hyödynnetään TROPOMI UV -algoritmin (Lindfors ym., 2018) käyttämän albedoklimatologian perusteella arvioituja lukuarvoja. Taulukko L1.1 esittää kullekin asemalle niitä albedoarvoja, joita käytettiin silloin kun satelliittipohjaisessa kuukausiaikasarjassa oli aukkoja.

17. Kokonaissäteily eri suunta- ja korkeuskulmille arvioidaan Perezin mallin (Perez ym., 1990) avulla. Malli kuvaa oleellisesti sitä, miten taivaalta tuleva hajasäteily käyttäytyy, huomioiden myös maanpinnasta heijastuneen säteilyn vaikutuksen. Malli on pärjännyt hyvin vertaisarvioiduissa vertailuissa, ja se on käytössä myös Ilmatieteen laitoksen aurinkoenergialaskelmissa. 
Taulukko L1.1: Klimatologiset maanpinnan albedon arvot, joita käytettiin vaiheissa 16-17 silloin, kun albedon satelliittipohjaisessa kuukausiaikasarjassa oli aukkoja.

\begin{tabular}{lrrrr}
\hline & Vantaa & Jokioinen & Jyväskylä & Sodankylä \\
\hline Tammikuu & 0.30 & 0.30 & 0.30 & 0.50 \\
Helmikuu & 0.32 & 0.34 & 0.30 & 0.50 \\
Maaliskuu & 0.28 & 0.29 & 0.32 & 0.48 \\
Huhtikuu & 0.13 & 0.14 & 0.19 & 0.45 \\
Toukokuu & 0.11 & 0.11 & 0.09 & 0.18 \\
Kesäkuu & 0.14 & 0.13 & 0.11 & 0.12 \\
Heinäkuu & 0.15 & 0.14 & 0.11 & 0.13 \\
Elokuu & 0.14 & 0.13 & 0.11 & 0.14 \\
Syyskuu & 0.14 & 0.13 & 0.11 & 0.13 \\
Lokakuu & 0.14 & 0.13 & 0.13 & 0.14 \\
Marraskuu & 0.14 & 0.14 & 0.14 & 0.20 \\
Joulukuu & 0.20 & 0.20 & 0.20 & 0.30 \\
\hline
\end{tabular}



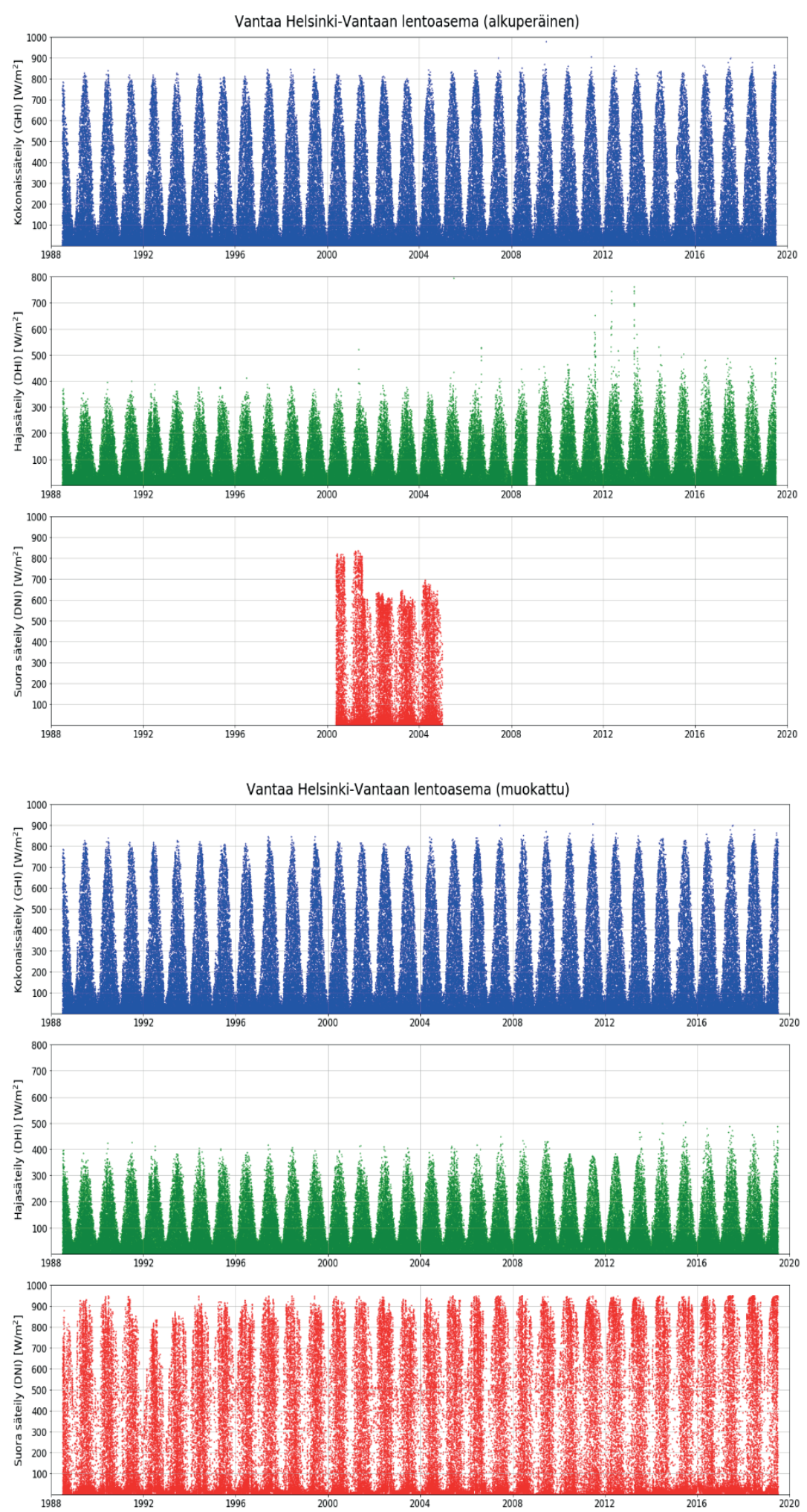

Kuva L1.1: Esimerkki alkuperäisten (ylhäällä) ja muokattujen (alhaalla) säteilyaikasarjojen $\left(\mathrm{W} / \mathrm{m}^{2}\right)$ vertailusta Helsinki-Vantaan lentoasemalla kesästä 1988 kesään 2019. Kokonaissäteily vaakapinnalle (GHI) on esitetty sinisellä, hajasäteily vaakapinnalle (DHI) vihreällä ja sädettä vastaan kohtisuora suora säteily (DNI) punaisella. 

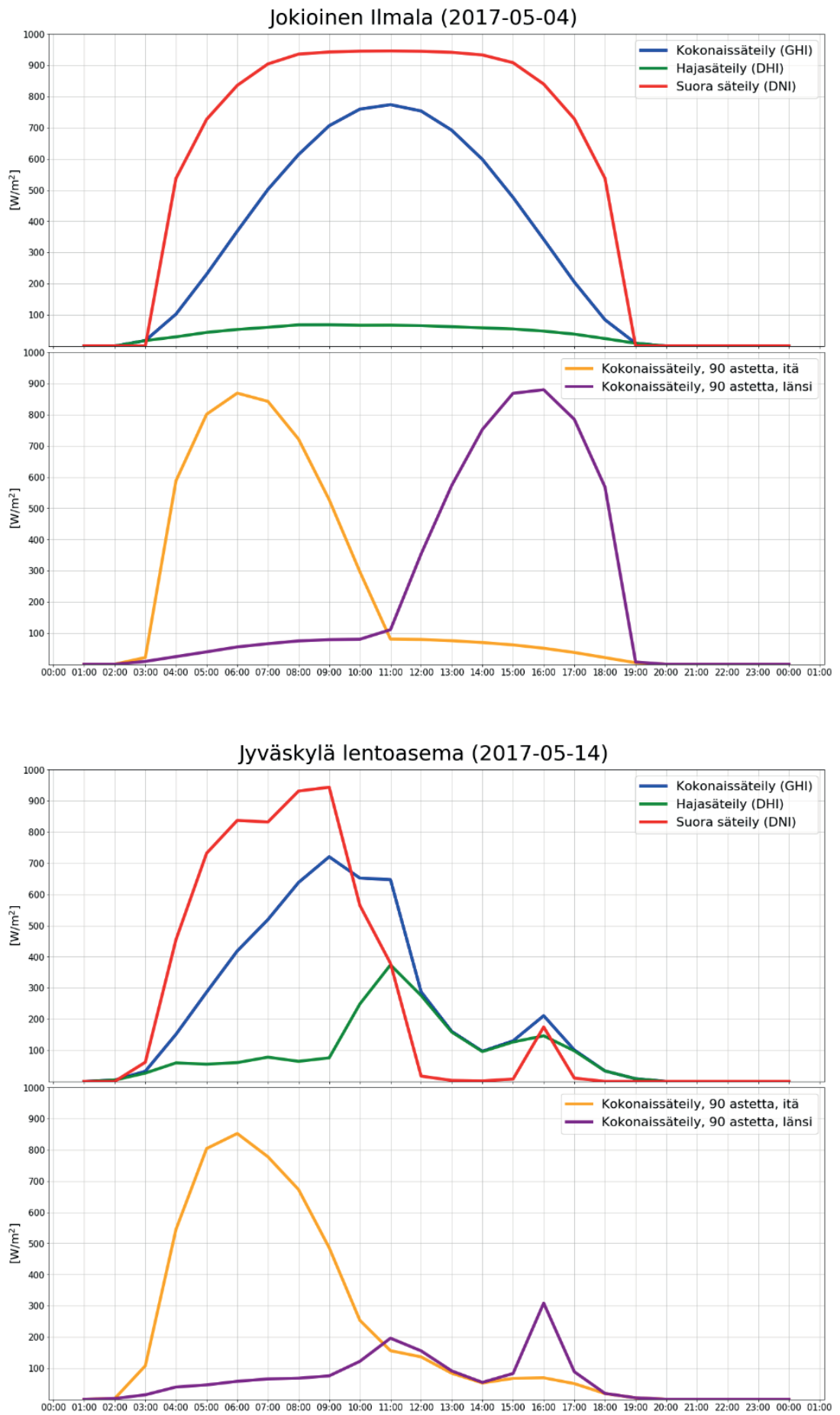

Kuva L1.2: Esimerkki säteilytehosta $\left(\mathrm{W} / \mathrm{m}^{2}\right)$ erisuuntaisilla pinnoilla Jokioisissa pilvettömänä päivänä (4.5.2017; ylhäällä) ja Jyväskylässä pilvisyyden lisääntyessä iltapäivällä (14.5.2017; alhaalla). Kokonaissäteily vaakapinnalle on esitetty sinisellä, hajasäteily vaakapinnalle vihreällä, sädettä vastaan kohtisuora suora säteily punaisella, kokonaissäteily itään osoittavalle pystypinnalle keltaisella ja kokonaissäteily länteen osoittavalle pystypinnalle violetilla käyrällä. Vaaka-akselina on aika tunteina. 


\section{Liite 2. Tunnittaisten sadetietojen laadinta}

\section{Yhteenveto}

- Tämä liite kuvaa nykyisen ilmaston tuntisadetietojen laadintaa. Pääpaino on sääilmiöitä koskevien havaintojen hyödyntämisessä. Liitteen loppuosassa tarkastellaan lyhyesti vaihtoehtoista tai täydentävää menetelmää, uusanalyysien käyttöä. Työssä on arvioitu neljän sääaseman (Vantaa, Jokioinen, Jyväskylä, Sodankylä) säätietojen ja 12 tunnin sadesummien pohjalta sateen määrää $(\mathrm{mm} / \mathrm{h})$ kunakin tarkastelujakson 1989-2018 tuntina näillä paikkakunnilla.

- Tuntisademäärien aikasarjat muodostettiin siten, että mitatut 12 tunnin sademäärät jaettiin tasaisesti niille tunneille, joita ei voitu osoittaa poutaisiksi.

- Sääilmiöitä koskevien havaintojen automatisointi kesken tarkastelujakson johti siihen, että jakson alku- ja loppupuolella jouduttiin käyttämään kahta keskenään hieman erilaista tuntisateiden arviointimenetelmää.

- Vertailujen perusteella menetelmät aliarvioivat poutaisen sään osuutta suurin piirtein saman verran. Yli 90 prosentissa vuoden 2009 tunneista menetelmät olivat yhtä mieltä poudan tai sateen sattumisesta. Menetelmät antoivat lähellä toisiaan olevia tuloksia myös tietyn sademäärän alittavien (tai ylittävien) tuntien osuudesta.

- Kun tarkasteltiin nykyisin käytössä olevien automaattisten säähavaintolaitteiden mittaamien vallitsevan sään tietojen perusteella sateisia tunteja, kahdella eri menetelmällä arvioitujen sademäärän tuntiarvojen välillä oli voimakas tilastollisesti merkitsevä korrelaatio (korrelaatiokerroin 0.83-0.87). Yksittäisille tunneille menetelmät saattoivat kuitenkin tuottaa toisistaan selvästi poikkeavia arvoja.

- Vertailujen perusteella voidaan sanoa, etteivät laadittujen tuntisateiden aikasarjojen tilastolliset ominaisuudet muuttuneet oleellisesti, kun käytettävää arviointimenetelmää muutettiin vuoden 2009 kohdalla.

- Tarvittavissa lähtötiedoissa olleet puutteet pyrittiin täydentämään ja ottamaan laskennallisesti huomioon mahdollisimman hyvin. Joitakin ajankohtia voisi mahdollisesti vielä tarkistaa esimerkiksi uusanalyysien tai säätutkahavaintojen perusteella.

- Laadittujen arvioiden mukaan suurimmat tunnin aikana saadut sademäärät vuosien 1989-2018 aikana olivat Vantaalla ja Jokioisissa vähintään 15 mm/h, Sodankylässä noin $5 \mathrm{~mm} / \mathrm{h}$ ja Jyväskylässä tältä väliltä. Säätutkamittausten perusteella nämä heinätai elokuussa sattuneet voimakkaat sateet liittyivät pienialaisiin sadekuurojonoihin tai laajemman sadealueen voimakkaasti konvektiivisiin vyöhykkeisiin.

Tavoitteena oli, että 30-vuotisjakson tuntisateiden aikasarjat olisivat mahdollisimman homogeenisia huolimatta manuaalisten havaintojen vähenemisestä ja automaattisten havaintojen lisääntymisestä jakson aikana. Vuodelta 2009 oli käytettävissä sekä manuaalisiin että automaattisiin havaintoihin perustuvat tulokset, joten niitä voitiin vertailla keskenään. Erillinen Jokioisten vuoden 2015 sadeaineisto koostuu sademäärän tuntihavainnoista ja myös sitä käytetään vertailuaineistona.

\section{L2.1 Aineistot}

\section{L2.1.1 Sademäärät 12 tunnin kertyminä}

Sääasemilla mitatut 12 tunnin sademäärät on kerätty jaksolta 29.12.1988 18 UTC - 2.1.2019 klo 18 UTC. Puuttuvat arvot on täydennetty eri tavoin seuraavassa järjestyksessä: 
- viereisen automaattianturin avulla (Vantaa, Jokioinen, Sodankylä)

- laskemalla 12 tunnin sademäärä automaattisista tuntisadehavainnoista (Jokioinen)

- laskemalla 12 tunnin sade mitatun vuorokauden sademäärän sekä 10 km:n hilaan interpoloitujen 3 tunnin sateiden avulla (Jokioinen, Jyväskylä)

Vielä näiden toimenpiteiden jälkeen Jokioisissa jäi puuttumaan kaksi 12 tunnin sadekertymän arvoa: 7.11.2010 klo 6 UTC ja 11.3.2011 klo 6 UTC. Kuukausisademäärän pitämiseksi ennallaan päädyttiin siihen, että edellisen havainnon (klo 18 UTC) sademäärä jaettiin tasan jaksoille 6.11.2010 klo 6-18 että 6.11. klo 18.-7.11. klo 18-06. Sääilmiöitä koskevien havaintojen mukaan (luku L2.1.3) mukaan sadetta oli tullut molempina jaksoina, joten puuttuvan 7.11.2010 klo 6 UTC havainnon korvaaminen poudalla olisi sekin ollut virheellistä. 11.3.2011 oli samanlainen tapaus.

Eri paikkakuntien 12 tunnin sadesummien aikasarjat ovat siis aukottomia. Jokioisten arvoja 7.11.2010 klo 6 UTC ja 11.3.2011 klo 6 UTC voisi kuitenkin tarvittaessa tarkastella kriittisesti esim. uusanalyysien avulla.

\section{L2.1.2 Tuntisateet Jokioisissa v. 2015}

Jokioisten vuoden 2015 sadeaineisto koostuu tunnin välein todellisesti mitatuista sadekertymistä (automaattihavainnot ovat saatavissa Jokioisista 24.5.2012 alkaen). https://hav.fmi.fi/hav/havainnot/?page $=$ suureet\&id $=61$

\section{L2.1.3 Sääilmiöt}

\section{i) Havainnontekijän kirjaamat sääkoodit jaksolle 1989-2009}

Kaikilta neljältä asemalta on jakson 1989-2009 ajalta käytettävissä manuaaliset havainnot esiintyneistä sääilmiöistä. Yksinkertaistaen sääilmiöt voidaan luokitella seuraavasti: pouta, utu, sumu, tihkusade, vesisade, lumisade, räntäsade, vesikuuro, lumikuuro, raesade ja ukkonen. Tarkemmin sanoen havainnontekijän kirjaamat sääilmiöitä kuvaavat koodit ilmoitettiin synoptisina havaintoaikoina $(00,03,06,09,12,15,18,21$ UTC) seuraavasti (Ilmatieteen laitoksen sääsähkeohjeet):

- Sää havaintohetkellä tai edellisen tunnin aikana (eli edellisen tasatunnin jälkeen): sadetta osoittavat ww-koodit ovat 20-27, 29 ja 50-99 (SYNOP Data Format (FM-12) Surface Synoptic Observations)

- Edellisen päähavaintoajan ja käsillä olevan havaintohetken välillä sattuneet tärkeimmät sääilmiöt: sadetta (tai ainakin ukkosta) osoittavat $\mathrm{W}_{1}$ - ja $\mathrm{W}_{2}$-koodiluvut ovat 5-9.

- Jos kysymyksessä on havainto klo 00, 06, 12 tai 18 UTC, $\mathrm{W}_{1-}$ ja $\mathrm{W}_{2}$-koodit kuvaavat kuuden edellisen tunnin säähavaintoja.

- Jos kysymyksessä on havainto klo 03, 09, 15 tai 21 UTC, W1- ja W2-koodit kuvaavat kolmen edellisen tunnin säähavaintoja.

- $\quad W_{1}$ - ja W2-koodeilla ilmoitetaan ensisijaisesti niitä havaittuja ilmiöitä, jotka eivät käy ilmi havaintohetken sään koodiluvusta ww. Jos sää on ollut samanlaista edellisestä päähavaintohetkestä käsillä olevaan havaintohetkeen asti, ww, $\mathrm{W}_{1}$ ja $\mathrm{W}_{2}$ osoittavat samaa sääilmiötä. Jos sää on vaihdellut edellisen päähavaintohetken jälkeen, $W_{1}$ ja $W_{2}$ voivat poiketa toisistaan $\left(\mathrm{W}_{1}>\mathrm{W}_{2}\right)$. 


\section{ii) Automaattiset vallitsevan sään mittaukset jaksolle 2009-2018}

Automaattisista mittauksista saadaan hetkellisinä arvoina vallitsevan säätä koskevat tiedot (https://hav.fmi.fi/hav/havainnot/?page=suureet\&id=56), joista arvot 40-89 merkitsevät sadetta. Havaintoja tunnissa on vuodesta ja havaintoasemasta riippuen 1 tai 10 min välien.

Aluksi on kerätty tunnin välein sadekoodien ja kaikkein sääkoodien lukumäärä edeltäneen tunnin aikana (esim. klo 13 arvo tarkoittaa jaksoa 12.01-13.00). Näistä on sitten laskettu sateisen ja poutaisen sään osuudet kunakin tuntina.

Puuttuvaa dataa vallitsevan sään mittaustiedoissa oli seuraavasti: Vantaalla 10, Jokioisissa 4, Jyväskylässä 36 ja Sodankylässä 498 tuntina (Rovaniemeltä olisi saanut dataa, mutta se sijaitsee aika kaukana Sodankylästä).

\section{L2.2 Menetelmät}

\section{L2.2.1 Manuaalisiin sääkoodeihin perustuva menetelmä jaksolle 1989-2009}

Sadetta, poutaa tai puuttuvaa tietoa osoittavat indikaattorit (0: poutaa, 1: sadetta, -9: puuttuva) määritetään manuaalisiin sääkoodeihin ( $\mathrm{ww}, \mathrm{W}_{1}$ ja $\mathrm{W}_{2}$ ) perustuen seuraavalla tavalla vuosien 1989-2009 jokaiselle kolmen tunnin jaksolle. Kutakin kolmea sääkoodia vastaava indikaattori "nimetään" yhdelle jakson kolmesta tunnista: ww-koodia vastaava indikaattori havaintohetkeä edeltäneelle tunnille, $\mathrm{W}_{1}$ - ja $\mathrm{W}_{2}$-koodeja vastaavat indikaattorit kahdelle edellisille tunneille.

Jos kuitenkin kysymyksessä on havaintohetki klo 00, 06, 12 tai 18 UTC, jolloin $W_{1-}$ ja $\mathrm{W}_{2-}$ koodit kuvaavat kuuden edellisen tunnin säähavaintoja, otetaan huomioon myös kolme tuntia aiemmin raportoidut sääkoodit seuraavalla tavalla. Jos havaintohetken sääkoodit ww ja $\mathrm{W}_{1}$ kertovat sateesta, mutta $\mathrm{W}_{2}$ poudasta ja kuuden tunnin jakson ensimmäisen puoliskon ajalta on vähintään kaksi poutaa ilmaisevaa sääkoodia, tulkitaan, että kyseinen $\mathrm{W}_{2}$ viittaa kuuden tunnin jakson ensimmäiseen puoliskoon. Tavoitteena on mieluummin ali- kuin yliarvioida poudan osuutta samalla kuitenkin hyödyntäen kaikki kolme sääkoodia (ww, $\mathrm{W}_{1}$ ja $\mathrm{W}_{2}$ ). Koska pyritään tunnistamaan poutaiset säätilanteet, sadesään indikaattori (arvo 1) kertoo, että on varmasti satanut tai tieto on epävarma (mutta ei puuttuva).

Kun on saatu tunnistettua poutaiset tunnit, 12 tunnin aikana kertynyt sademäärä jaetaan tasan loppujen tuntien kesken. Puuttuvat sääkoodit tulkitaan tunneiksi, joiden aikana on mahdollisesti satanut. Jos 12 tunnin sademäärä on nolla, myös tuntisademäärät merkitään nolliksi riippumatta ww-, $W_{1}$ - ja $W_{2}$-sääkoodeista. Jos taas 12 tunnin sademäärä $>0$, mutta sääkoodien mukaan on ollut sateetonta koko jakson ajan, sademäärä jaetaan tasan 12 tunnille.

Tässä työssä jaksolle 1989-2018 käytetty menetelmä perustuu aiemmin kehitettyyn menetelmään jaksolle 1980-2009 (Ruosteenoja ym. 2013). Tuolloin ei kuitenkaan otettu huomioon ww-, W1- ja W2-sääkoodeja koskeneita ohjeita yhtä tarkasti kuin nyt, vaan tyydyttiin tunnistamaan yhden tunnin asemesta kolmen tunnin poutaiset jaksot. Toisaalta koska oli tiedossa, että menetelmä jätti käyttämättä huomattavan määrän tietoa, valittujen rakennusfysiikan ilmastollisten testivuosien (Jokioinen 2004 ja Vantaa 2007; Vinha ym., 2013) tuntisademäärät tarkennettiin tuolloin tutkasadehavaintojen avulla. 


\section{L2.2.2 Vallitsevan sään mittauksiin perustuva menetelmä jaksolle 2009-2018}

Automaattisesti mitattujen vallitsevan sään hetkellisarvojen (luku L2.1.3) perusteella lasketaan ensin jakson 2009-2018 kullekin tunnille sateisen ja poutaisen sään osuudet ajasta. Tavoitteena on eliminoida ne yhden tunnin jaksot, joina ei ole satanut. Esimerkiksi klo 13 sääkoodeiksi lasketaan ne koodit, jotka on kirjattu tietokantaan aikaleimoilla 12:01 .. 13:00. Koska mittauksia tehtiin havaintoasemasta ja vuodesta riippuen 1 tai 10 minuutin välein, sateiseksi tunniksi luokitellaan tapaukset, joissa wawa-sääkoodien mukaan sateen osuus oli vähintään 1/6 tai wawa-koodi puuttui. Mitattu 12 tunnin sademäärä jaetaan sitten tasan niiden tuntien kesken, joiden aikana on varmasti tai mahdollisesti satanut. Kunkin 12 tunnin jakson yksittäisinä tunteina sademäärä on siis joko nolla (poutaa) tai vakio (=12 tunnin sademäärä jaettuna poudattomien tuntien määrällä). Jos 12 tunnin sademäärä on nolla, myös tuntisademäärät merkitään nolliksi riippumatta wawa-sääkoodeista. Jos taas 12 tunnin sademäärä $>0$, mutta wawa-sääkoodien mukaan on ollut sateetonta kaikkina jakson havaintoaikoina, sademäärä jaetaan tasan 12 tunnille.

Edellä kuvatulle menetelmälle vaihtoehtoinen tapa olisi ollut jakaa 12 tunnin sademäärä tuntisateiksi sen perusteella, kuinka suuri oli sadesään (poudan puuttumisen) ajallinen osuus kunakin tuntina. Tällöin nollasta poikkeavat tuntisademäärät olisivat vaihdelleet kyseisen 12 tunnin jakson aikana. Samalla olisi tosin tehty implisiittisesti oletus, että sateen aikainen sateen intensiteetti olisi ollut vakio. Tätä vaihtoehtoa ei kuitenkaan käytetty, koska manuaalisten havaintojen aikakaudelta (luku L2.2.1) ei ollut vastaavaa tietoa sade-/poutasään osuuksista kunakin tuntina.

Olisi myös ollut mahdollista tarkastella synoptisia havaintoaikoja edeltäneitä kolmen tunnin jaksoja, etsiä varmat kolmen tunnin täysin poutaiset jaksot ja jakaa mitattu sademäärä tasan jäljelle jääville kolmen tunnin jaksoille, joiden aikana oli varmasti tai mahdollisesti satanut. Menetelmä jättäisi kuitenkin käyttämättä huomattavan määrän tietoa.

Pohdittavana oli myös, kuinka pieni ajallinen osuus anturin havaitsemaa sateista säätä per tunti tarvitaan siihen, että kyseisestä tuntia ei pidetä poutatuntina. Päädyttiin määritelmään, että lyhytkin sade tarkoittaa sateista tuntia. Jos vallitsevan sään tietoja saatiin 10 minuutin välein, jo yksikin automaattinen säätieto sateesta tunnin aikana riitti tekemään tunnista sateisen. Jos havaintoja tehtiin minuutin välein, raja-arvona oli 10/60 eli 0.0167. Lisää aiheesta on luvussa L2.3.

\section{L2.2.3 Aikasarjojen yhdistäminen}

Arvioiduista tuntisademääristä muodostetaan siis kaksi aikasarjaa kullekin havaintoasemalla, toinen jaksolle 1989-2009 ja toinen jaksolle 2009-2018. Seuraavassa luvussa esitettävien vertailujen perusteella ei ole kovin suurta merkitystä sillä, kummasta aikasarjasta vuoden 2009 arviot otetaan. Päädyttiin käyttämään jälkimmäisen aikasarjan ensimmäistä vuotta.

\section{L2.3 Menetelmien vertailua}

Käytettyjen tuntisateiden arviointimenetelmien testaamiseksi on tehty kahdenlaisia vertailuja, ensin vuodelle 2009 kaikkien neljän aseman dataa käyttäen ja sitten vuodelle 2015 Jokioisten datan avulla. Ensimmäisten vertailujen tarkoituksena on selvittää, kuinka yhteneväisiä tuloksia tarkastelujakson alku- ja loppupuolella käytetyt menetelmät antavat. Vuoden 2009 vertailu koskee siis aiheutuvia eroja, kun 12 tunnin sademäärä jaetaan tuntisateiksi käyttäen tuota vuotta 
varten saatavissa olevaan kahta vaihtoehtoista lähtötietoa: joko manuaalisia sääkoodeja tai automaattisesti mitattuja vallitsevan sään hetkellisarvoja. Toivottavaa on, etteivät laadittujen tuntisateiden aikasarjojen tilastolliset ominaisuudet muuttuisi oleellisesti, kun käytettävää arviointimenetelmää joudutaan muuttamaan säähavaintojen automatisoinnin takia. Vuotta 2015 koskevan vertailun tarkoituksena on puolestaan selvittää, missä määrin vallitsevan sään hetkellisarvojen ja 12 tunnin sadesumman avulla arvioituidut tuntisademäärät vastaavat Jokioisissa automaattisin anturein mitattuja tunnin sademääriä.

\section{L2.3.1 Vuosi 2009}

Sekä tarkastelujakson alku- että loppupuolella käytettyjen menetelmien perusteella suurin osa vuoden 2009 tunneista, noin $80 \%$, oli poutaisia kaikilla neljällä havaintoasemalla (taulukko L2.1). Kuten oli etukäteen odotettavissa, manuaalisiin sääkoodeihin perustuva menetelmä tuotti hieman pienemmän määrän poutatunteja kuin automaattisiin vallitsevan sään tietoihin perustuva menetelmä, mutta erot ovat pieniä, prosenttiyksiköissä välillä $0.4 \%$ (Jokioinen) ja 1.3\% (Sodankylä). Tarkasteltaessa sitä, miten usein menetelmät olivat yhtä mieltä poudan tai sateen sattumisesta, nähdään, että näin oli 92-94 prosentissa tapauksista.

Taulukon L2.1 tulokset tukevat edellisessä luvussa tehtyjä menetelmällisiä ratkaisuja. Manuaalisia sääkoodeja hyödynnettäessä päätettiin pyrkiä tunnistamaan poutaiset tunnit, ei pelkästään poutaiset kolmen tunnin jaksot, ja sen takia otettiin huomioon myös kolme tuntia aiemmin raportoidut sääkoodit (luku L2.2.1). Automaattisia wawa-tietoja koskeva päätös oli käyttää määritelmää, jonka mukaan lyhytkin sade tarkoittaa sateista tuntia (luku L2.2.2).

Taulukko L2.1: Havainnontekijän raportoimien sääkoodien avulla arvioitujen poutaisten ja sateisten (sademäärä $>0 \mathrm{~mm} / \mathrm{h}$ ) tuntien ajalliset osuudet (\%) verrattuna automaattisten valitsevan sään mittausten avulla arvioituihin vastaaviin osuuksiin Vantaalla, Jokioisissa, Jyväskylässä ja Sodankylässä v. 2009. Lukemat ovat prosentteja siitä ajasta, jolloin molempia arvioita oli tehtävissä. Molemmissa arviointimenetelmissä hyödynnettiin myös mitattuja 12 tunnin sadesummia.

\begin{tabular}{lccc}
\hline Vantaa 2009 & Pouta, sääkoodit & Sade, sääkoodit & Yht. \\
\hline Pouta, vallitseva sää & 77.8 & 3.7 & 81.5 \\
\hline Sade, vallitseva sää & 3.1 & 15.4 & 18.5 \\
\hline Yht. & 80.8 & 19.2 & 100.0 \\
\hline \hline Jokioinen 2009 & Pouta, sääkoodit & Sade, sääkoodit & Yht. \\
\hline Pouta, vallitseva sää & 77.0 & 4.4 & 81.4 \\
\hline Sade, vallitseva sää & 4.0 & 14.7 & 18.6 \\
\hline Yht. & 81.0 & 19.0 & 100.0 \\
\hline \hline Jyväskylä 2009 & Pouta, sääkoodit & Sade, sääkoodit & Yht. \\
\hline Pouta, vallitseva sää & 77.3 & 3.6 & 80.9 \\
\hline Sade, vallitseva sää & 2.4 & 16.7 & 19.1 \\
\hline Yht. & 79.7 & 20.3 & 100.0 \\
\hline \hline Sodankylä 2009 & Pouta, sääkoodit & Sade, sääkoodit & Yht. \\
\hline Pouta, vallitseva sää & 76.4 & 3.7 & 80.1 \\
\hline Sade, vallitseva sää & 2.4 & 17.5 & 19.9 \\
\hline Yht. & 78.8 & 21.2 & 100.0 \\
\hline
\end{tabular}


Näiden kahden menetelmän perusteella saadut tuntisademäärien summafrekvenssijakaumat ovat hyvin lähellä toisiaan. Tulosten mukaan poutaisen tai heikkosateisen (tuntisade $<0.1$ $\mathrm{mm} / \mathrm{h}$ ) sään osuus vuonna 2009 oli automaattisten vallitsevan sään mittausten perusteella Vantaalla $86.5 \%$ ja lähes yhtä suuri manuaalisten sääkoodien perusteella (menetelmien ero $0.16 \%$-yksikköä). Vastaavat osuudet (ja menetelmien erot) olivat Jokioisissa 88.2 \% (0.03\%yksikköä), Jyväskylässä 88.6 \% (-0.08 \%-yksikköä) ja Sodankylässä $88.4 \%$ (0.22 \%yksikköä). Prosenttiyksiköissä eniten kahteen eri menetelmään perustuvat summafrekvenssijakaumat poikkeavat toisistaan Jokioisissa säätilanteille, joissa sademäärä on enintään 0.6-0.7 $\mathrm{mm} / \mathrm{h}$ (kuva L2.1). Suhteellisesti ottaen erot kasvavat kohti harvinaisimpia sateen intensiteettejä, kuten ilmenee käänteisistä summafrekvessijakaumista (kuva L2.1).
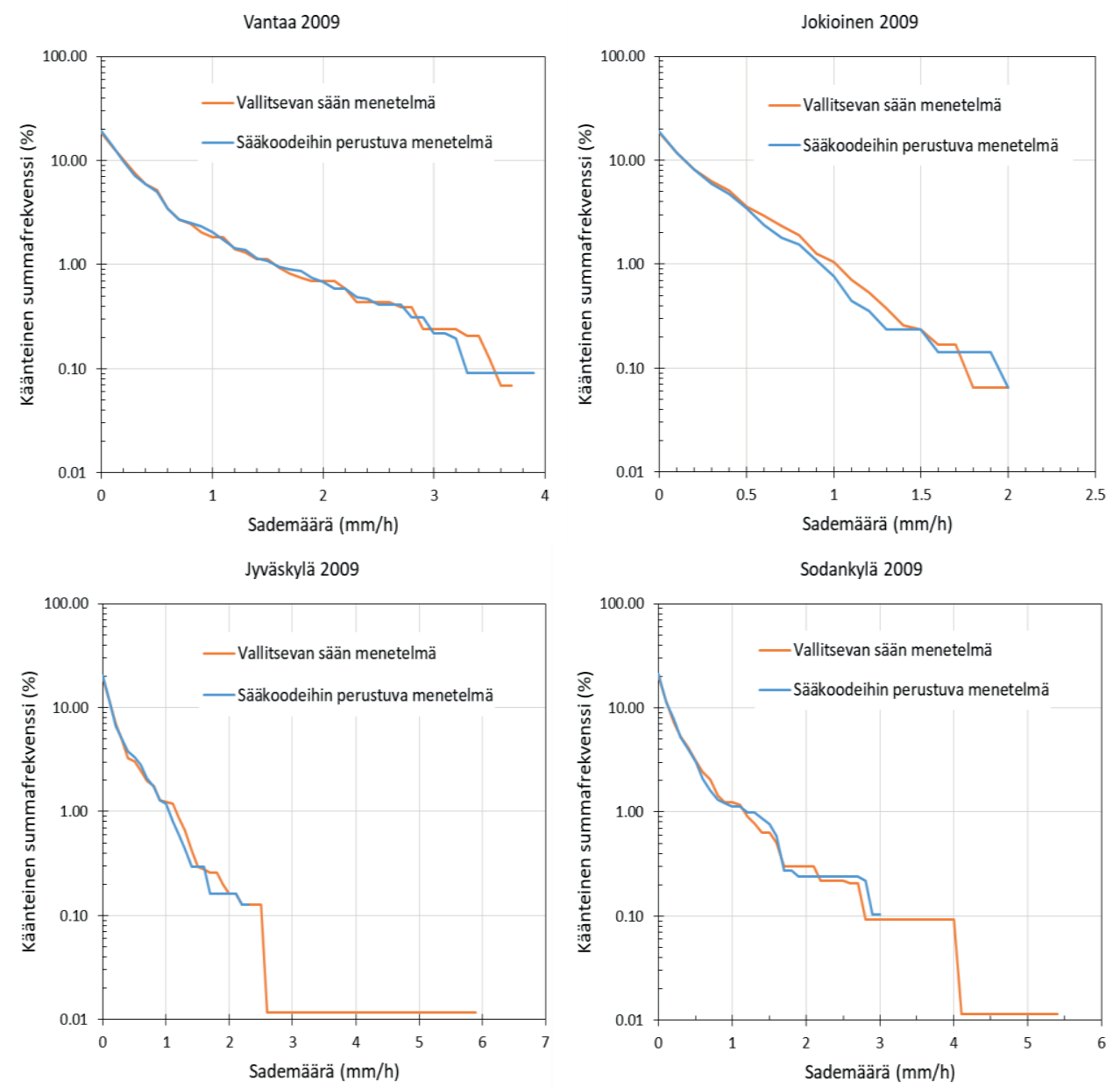

Kuva L2.1: Tuntisademäärien käänteiset summafrekvenssijakaumat Vantaalla, Jokioisissa, Juväskylässä ja Sodankylässä v. 2009 arvioituina automaattisten valitsevan sään mittausten avulla (punaiset käyrät) ja havainnontekijän raportoimien sääkoodin avulla (siniset käyrät). Molemmissa menetelmissä käytetään 12 tunnin sademäärän mittauksia. Pystyakseli esittää todennäköisyyttä (\%), että sademäärä on vähintään vaaka-akselin osoittaman arvon suuruinen.

Kuten jo taulukosta L2.1 saattoi ounastella, poutaisten tuntien lukumäärä kussakin 12 tunnin jaksossa korreloi tilastollisesti merkitsevästi kahden eri menetelmän avulla arvioituna. Korrelaatiokertoimet olivat Vantaalle $0.91\left(p<10^{-5}\right)$, Jokioisille $0.85\left(p<10^{-15}\right)$, Jyväskylälle $0.92\left(p<10^{-15}\right)$ ja Sodankylälle $0.92\left(p<10^{-15}\right)$. Koska 6-8 prosentissa kaikista tunneista menetelmät olivat kuitenkin erimielisiä sateen sattumisesta (taulukko L2.1), tuntisademäärien 
pistediagrammit osoittavat useita tapauksia, joissa toisen menetelmän mukaan satoi runsaasti, mutta toisen mukaan vallitsi pouta (kuva L2.2). Esimerkkitapausten avulla voitiin kuitenkin todeta, että kyseessä oli ainakin toisinaan vain tunnin tai kahden ero siinä, mille tunneille mitattu 12 tunnin sademäärä jaettiin eri menetelmien perusteella.

Kun otettiin huomioon kaikki säätilanteet, kahteen eri menetelmään perustuvien tuntisateiden väliset korrelaatiot eivät osoittautuneet tilastollisesti merkitseviksi. Jos taas keskityttiin automaattisten vallitsevan sään tietojen perusteella sateisiin tunteihin $(>0 \mathrm{~mm} / \mathrm{h})$, saatiin tulokseksi, että tuntisademäräät korreloivat tilastollisesti merkitsevästi. Korrelaatiokertoimet olivat Vantaalla $0.83(p<0.002)$, Jokioisissa $0.83\left(p<10^{-7}\right)$, Jyväskylässä $0.89(p<0.002)$ ja Sodankylässä $0.87(p<0.002)$.

Tehtyjen vertailujen perusteella tarkastelujakson 1989-2018 alku- ja loppupuolella käytetyt menetelmät antavat varsin yhteneväisiä tuloksia poudan ja sateen yleisyydestä sekä tietyn sademäärän alittavien (tai ylittävien) tuntien osuudesta vuonna 2009. Yksittäisille tunneille menetelmät voivat kuitenkin tuottaa toisistaan selvästi poikkeavia tuloksia (kuva L2.2).
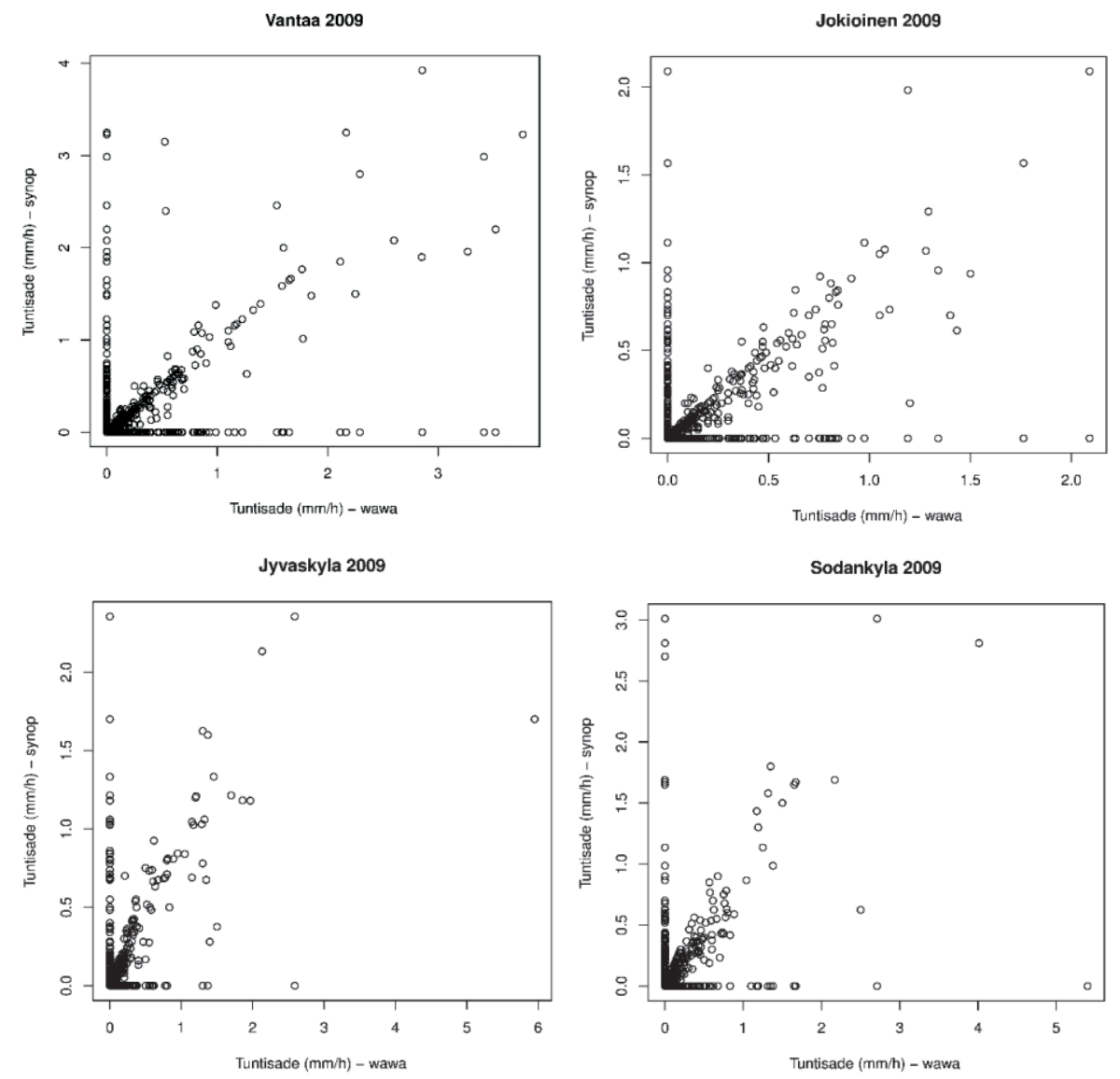

Kuva L2.2: Tuntisademäärienn $(\mathrm{mm} / \mathrm{h})$ arviot, kun ne perustuvat automaattisiin vallitsevan sään mittauksiin (vaaka-akseli) tai havainnontekijän ilmoittamiin sääkoodeihin (pystyakseli) v. 2009 Vantaalla, Jokioisissa, Jyväskylässä ja Sodankylässä. Molemmissa menetelmissä käytetään 12 tunnin sademäärän mittauksia. Huomaa akselien toisistaan poikkeavat asteikot. 


\section{L2.3.2 Jokioinen 2015}

Vuoden 2009 aineistoja koskevien vertailujen perusteella voitiin edellä todeta, etteivät laadittujen tuntisateiden aikasarjojen poudan ja sateen yleisyyttä ja sateiden voimakkuutta koskevat ominaisuudet muutu oleellisesti, kun käytettävää arviointimenetelmää joudutaan muuttamaan säähavaintojen automatisoinnin takia. Jäljelle jää kuitenkin kysymys, kuinka hyvin epäsuorasti arvioidut tuntisademäärät vastaavat suoria automaattisin anturein mitattuja tunnin sademääriä.

Rakennusfysiikaalisten tarkastelujen vertailuvuotta varten on koottu erikseen Jokioisissa automaattisesti mitatut tunnin sademäärät vuodelta 2015 (luku 2.4). Näitä verrataan seuraavassa arvioihin, jotka on saatu tarkastelujakson jälkipuolella käytetyllä menetelmällä, jossa mitatut 12 tunnin sadesummat jaetaan tuntisademääriksi vallitsevan sään hetkellisistä mittausarvoista määritettyjen pouta- ja sadetuntien perusteella.

Taulukko L2.2: Automaattisten valitsevan sään ja 12 tunnin sademäärien mittausten avulla arvioidut sateiset (sademäärä $>0 \mathrm{~mm} / \mathrm{h}$ ) ja poutaiset tunnit verrattuna automaattisiin tuntisademäärän mittauksiin Jokioisissa v. 2015. Lukemat ovat prosentteja ajasta, jolloin molempia mittauksia oli saatavilla.

\begin{tabular}{lccc}
\hline Jokioinen 2015 & Pouta, vallitseva sää & Sade, vallitseva sää & Yht. \\
\hline Pouta, mitattu & 74.3 & 9.3 & 83.6 \\
Sade, mitattu & 0.7 & 15.7 & 16.4 \\
Yht. & 75.0 & 25.0 & 100.0 \\
\hline
\end{tabular}

Suorien sademittausten perusteella perusteella suurin osa vuoden 2015 tunneista, noin $84 \%$, oli poutaisia, kun taas epäsuora, automaattisiin vallitsevan sään mittaustietoihin perustuva menetelmä antoi poudan osuudeksi vain $75 \%$ (taulukko L2.2). Sademittaukset ja arviointimenetelmä olivat yhtä mieltä poudan tai sateen sattumisesta 90 prosentissa tapauksista. Vallitsevan sään mittauksiin pohjautuen päädyttiin siis luokittelemaan tarkasteltava tunti sateiseksi huomattavasti useammin kuin mitä suora sademittaus kertoi. Hyvin harvoin, alle 1 prosentissa tapauksista sattui niin, että sadetta olisi mitattu, vaikka vallitsevan sään mittausten mukaan olisi ollut poutaa.

Kuten muinakin jakson 2009-2018 vuosina, myös vuonna 2015 vallitsevan sään mittauksia tehtiin Jokioisissa 10 minuutin välein eli kuudesti tunnissa. Taulukon L2.2 perusteella vaikuttaisi perustellulta vaatia, että useamman kuin yhden kuudesta vallitsevan sään mittauksesta pitäisi osoittaa sadetta, jotta tunti luokiteltaisiin sateiseksi. Tähän määritelmään ei kuitenkaan menty, koska se olisi mitä todennäköisimmin huonontanut kahden eri arviointimenetelmän vertailutuloksia. On siis tärkeää pitää mielessä, että molemmat arviointimenetelmät aliarvioivat täysin poutaisen sään osuutta, mutta kuta kuinkin yhtä paljon.

Toisaalta poutaisten tai lähes sateettomien tuntien (sademäärä alle $0,1 \mathrm{~mm} / \mathrm{h}$ ) osuus oli suorien mittausten ja arviointimenetelmän perusteella lähes sama: $83.6 \%$ mitattuna ja $82.6 \%$ arvioituna. Mittausten mukaan tuntisademäärä oli vähintään $1 \mathrm{~mm} / \mathrm{h} 1.8 \%$ koko vuoden ajasta, ja arvion mukaan osuus oli noin kolmanneksen pienempi, $1.3 \%$. Eniten arviointimenetelmä yliarvioi suuruudeltaan $[0.3,0.6[\mathrm{~mm} / \mathrm{h}$ olevien tuntisateiden osuutta.

Jos tarkastellaan vain tunteja, jolloin automaattinen sademittari on havainnut sadetta edes hieman $(>0 \mathrm{~mm} / \mathrm{h})$, saadaan mittausten ja arvioiden väliseksi tilastollisesti merkitseväksi 
korrelaatioksi $0.64\left(\mathrm{p}<10^{-4}\right)$. Mittausten mukainen tuntisademäärien mediaani, keskiarvo ja maksimi ovat $0.20,0.48 \mathrm{ja} 11.6 \mathrm{~mm} / \mathrm{h}$, kun taas vastaavat arviot ovat $0.23,0.38 \mathrm{ja} 8.5 \mathrm{~mm} / \mathrm{h}$. Näiden tulosten perusteella arviointimenetelmä kuvaa varsin hyvin tuntisateiden tilastollisia ominaisuuksia v. 2015, joskin se hieman yliarvioi sateisten tuntien sademäärän mediaania ja aliarvioi keskiarvoa.

On kuitenkin huomattava, että yksittäistapauksissa arviot ja suorat mittaukset voivat poiketa paljonkin toisistaan (kuva L2.3). Suurin yhden tunnin sademäärä, $11.6 \mathrm{~mm}$, mitattiin 30.8 . klo 10-11 UTC. Vettä satoi myös kolmen seuraavan tunnin aikana, ja koko 12 tunnin sademäärä klo 6-18 UTC oli 19,2 mm. Tuolloin 10 minuutin välein raportoinut vallitsevan sään anturi rekisteröi sadetta noiden neljän tunnin aikana, mutta kahdesti myös klo 15-17 välisenä aikana, vaikka automaattinen sademittari ei tuolloin enää havainnut sadetta. Niinpä arviointimenetemä jakoi sademäärän $19.2 \mathrm{~mm}$ tasan kuudelle tunnille, ja suurinta havaintoarvoa $11.6 \mathrm{~mm} / \mathrm{h}$ tuli näin vastamaan arvio $3.2 \mathrm{~mm} / \mathrm{h}$.

Päinvastainen esimerkki on elokuun alusta 2015, jolloin arviointimenetelmä toimi osin sattumoisin erittäin hyvin. Tuolloin mitattu sademäärä ajalta 2.8. klo 06-18 UTC oli 4.4 mm/12 h, ja seuraavan 12 tunnin kertymäksi mitattiin $8.5 \mathrm{~mm} / 12 \mathrm{~h}$. Hetkelliset vallitsevan sään mittaukset raportoivat sadetta vain klo 17-19. Niinpä arviointimenetelmä antoi klo 17-8 väliseksi sademääräksi $4.4 \mathrm{~mm} / \mathrm{h}$ ja seuraavalle tunnille $8.5 \mathrm{~mm} / \mathrm{h}$. Automaattisten tuntisademittausten tulokset olivat lähes samat: $4.4 \mathrm{~mm} / \mathrm{h}$ klo $17-18,8.4 \mathrm{~mm} / \mathrm{h}$ klo $18-19$ ja 0.1 $\mathrm{mm} / \mathrm{h}$ klo 19-20.

Kuten kuvasta L2.3b ilmenee, arvioitujen tuntisateiden joukossa on suuri määrä alle $0.1 \mathrm{~mm} / \mathrm{h}: \mathrm{n}$ arvoja, kun taas mitatut sateen on ilmoitettu $0.1 \mathrm{~mm} / \mathrm{h}$ tarkkuudella. Pienet hyvin heikot tuntisateet aiheutuvat laskennallisesti siitä, että pienin mitattu 12 tunnin sademäärä, $0.1 \mathrm{~mm} / 12 \mathrm{~h}$ on saatettu joutua jakamaan tasan jopa kaikille 12 tunnille, jolloin tulokseksi saadaan 0.008 $\mathrm{mm} / \mathrm{h}$. Näitä tapauksia ei ole kuitenkaan merkitty poutaisiksi tunneiksi, jotta 12 tunnin sadesumma pysyisi oikeana.
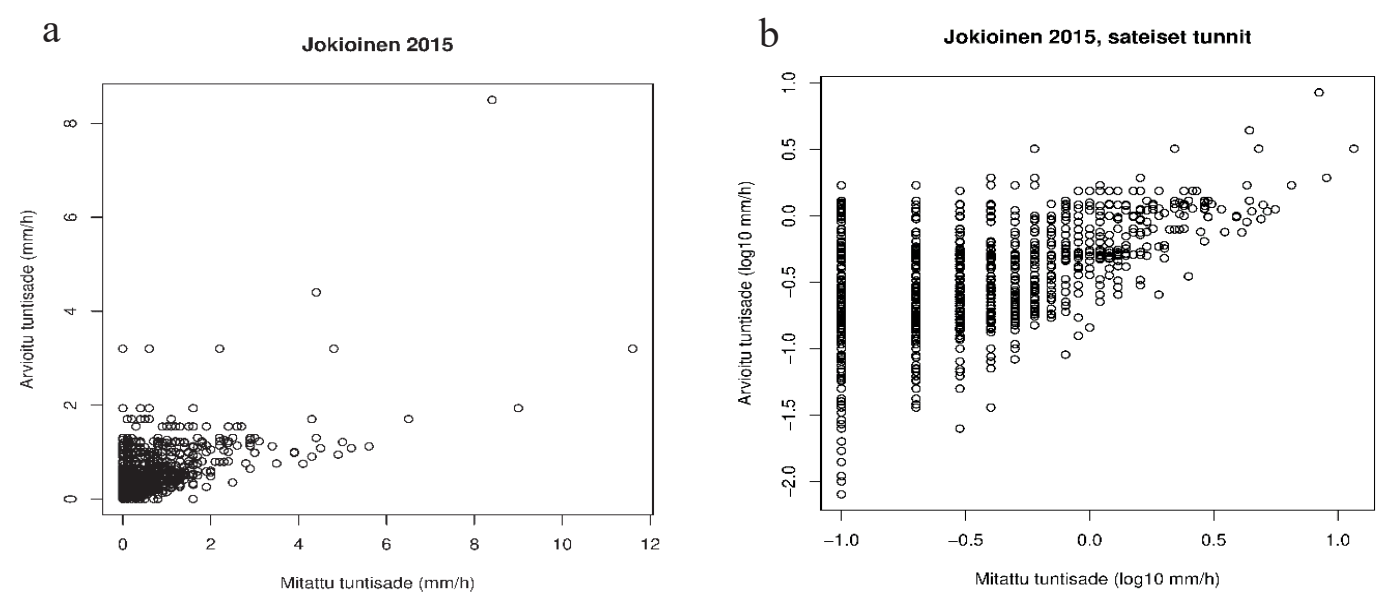

Kuva L2.3: Automaattisten valitsevan sään mittausten avulla arvioidut tuntisademäärät verrattuna automaattisiin tuntisademäärän mittauksiin Jokioisissa v. 2015 a) lineaarisella ja b) logaritmisella asteiteikolla. Poutaiset tunnit $(<0.1 \mathrm{~mm} / \mathrm{h})$ ovat a) mukana tai b) jätetty pois. 


\section{L2.4 Suurimmat arvioidut tuntisateet}

Laaditun aineiston mukaan suurimmat tunnin aikana tulleet sademäärät olivat Vantaalla 15.0 $\mathrm{mm} / \mathrm{h}$ (12.8.2017 klo 16-17), Jokioisissa $16.6 \mathrm{~mm} / \mathrm{h}$ (3.7.2011 sekä klo 12-13 että 13-14), Jyväskylässä 11.0 mm/h (10.7.2006 klo 15-16) ja Sodankylässä 5.4 mm/h (10.7.2009 klo 1819). Vantaalla, Jyväskylässä ja Sodankylässä koko 12 tunnin sademäärä pystyttiin kohdistamaan yhdelle tunnille, kun taas Jokioisten tapauksessa mitattu 12 tunnin sademäärä, $33.2 \mathrm{~mm} / 12 \mathrm{~h}$, jaettiin käytetyn menetelmän mukaisesti tasan kahdelle tunnille. Säätutkamittauksiin perustuvat kartat tunnin sademääristä kyseisinä ajankohtina on esitetty kuvassa L2.4. Nähdään, että suurimmat tuntisateet ovat aiheutuneet joko pienialaisista sadekuurojonoista (kuvat L2.4b ja d) tai laajempaan sadealueeseen kuuluneesta kapeasta konvektiivisesta vyöhykkeestä (kuvat L2.4a ja c). Näiden voimakkaiden sateiden ajallisesti ja alueellisesti tarkka kuvaaminen on tyypillisesti haastavaa uusanalyysien avulla (vrt. luku L2.5), kun taas tässä työssä käytetty lähestymistapa näyttää toimineen varsin hyvin.

a)

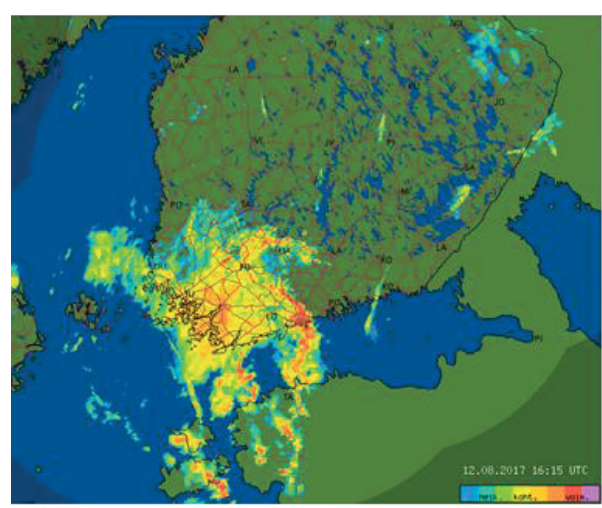

c)

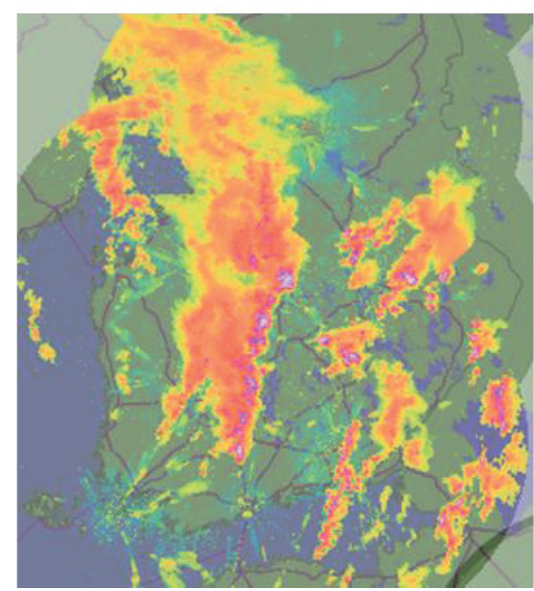

b)

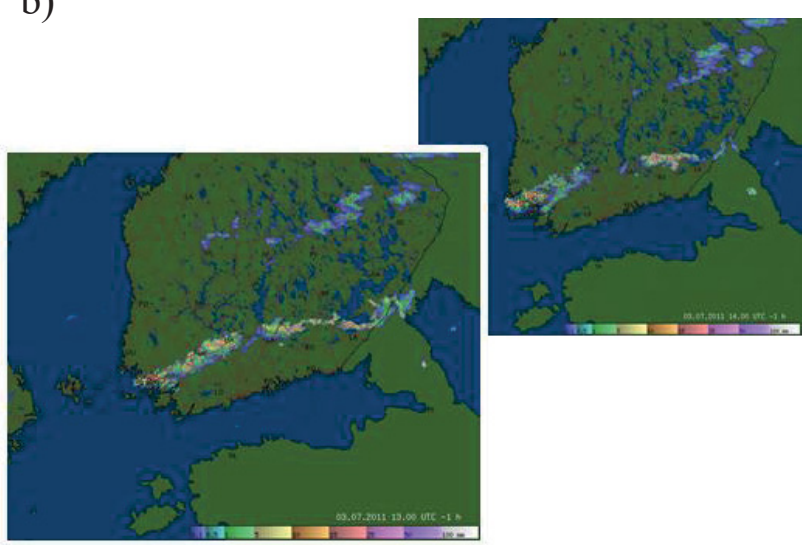

d)

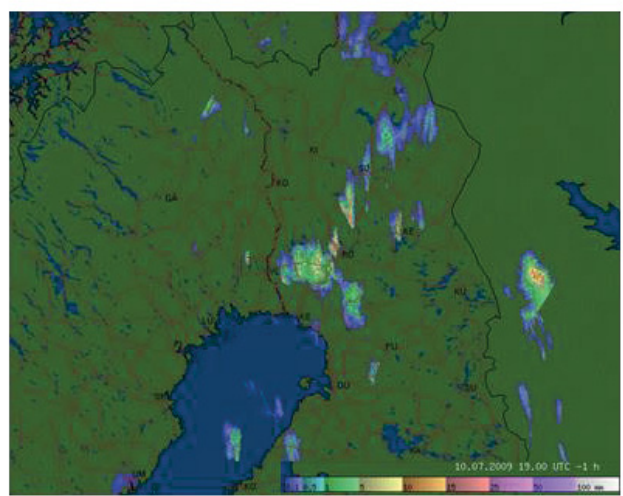

Kuva L2.4: Säätutkamittauksiin perustuvia karttoja sateen maantieteellisestä jakautumisesta voimakkaimpien tuntisateiden aikaan. (a) Vantaa: sateen voimakkuutta kuvaava tutkaheijastavuustekijä (dBZ) 12.8 .2017 klo 16.15 UTC. (b) Jokioinen: tunnin aikana kertynyt sademäärä (mm/h) 3.7.2011 klo 12-13 ja 13-14 UTC. (c) Jyväskylä: tutkaheijastavuustekijä (dBZ) 10.7.2006 klo 16.00 UTC (d) Sodankylä: tunnin aikana kertynyt sademäärä $(\mathrm{mm} / \mathrm{h})$ 10.7.2009 klo 18-19 UTC. 


\section{L2.5 Uusanalyysien vertailua säähavaintoihin}

Alkuperäisenä suunnitelmana oli hyödyntää tuntisademäärien arvioimisessa myös ERA5uusanalyysejä. Tässä luvussa arvioidaan niiden käyttökelpoisuutta vertailemalla analyysien antamia sademääriä vuonna 2015 aikana vastaaviin Jokioisten observatoriossa tehtyihin sadehavaintoihin. Tuona aikana sateita oli Jokioisissa nimittäin jo mitattu automaattisen sääaseman avulla tunnin välein.

Kuvassa L2.5 on tarkasteltu esimerkkinä mitattuja ja uusanalyysin tuottamia sademääriä kahden kuuden vuorokauden mittaisen ajanjakson aikana. Tammikuun alkupäivinä mitatut ja uusanalyysin sateet osuivat ajallisesti varsin hyvin yksiin. Kuitenkin analyysitiedoista peräisin olevat sateet vaihtelivat voimakkuudeltaan vähemmän. Erityisesti tammikuun 2. päivän runsas sade, mittausten mukaan enimmillään yli $3 \mathrm{~mm}$ tunnissa, näkyy uusanalyysissa noin puolta heikompana.

Toukokuun alkupäivinä yhteensopivuus on heikompi. Havaintojen mukaan sadetta saatiin vain lyhyen aikaa 3. päivänä. Tämän sadejakson myös uusanalyysi on tunnistanut, joskin jälleen liian heikkona ja myös hiukan liian myöhään ajoitettuna. Mutta sen lisäksi analyysi on kehittänyt kuukauden toiselle päivälle aivan oman yli puoli vuorokautta kestäneen sadejaksonsa, josta havainnoissa ei ole jälkeäkään.
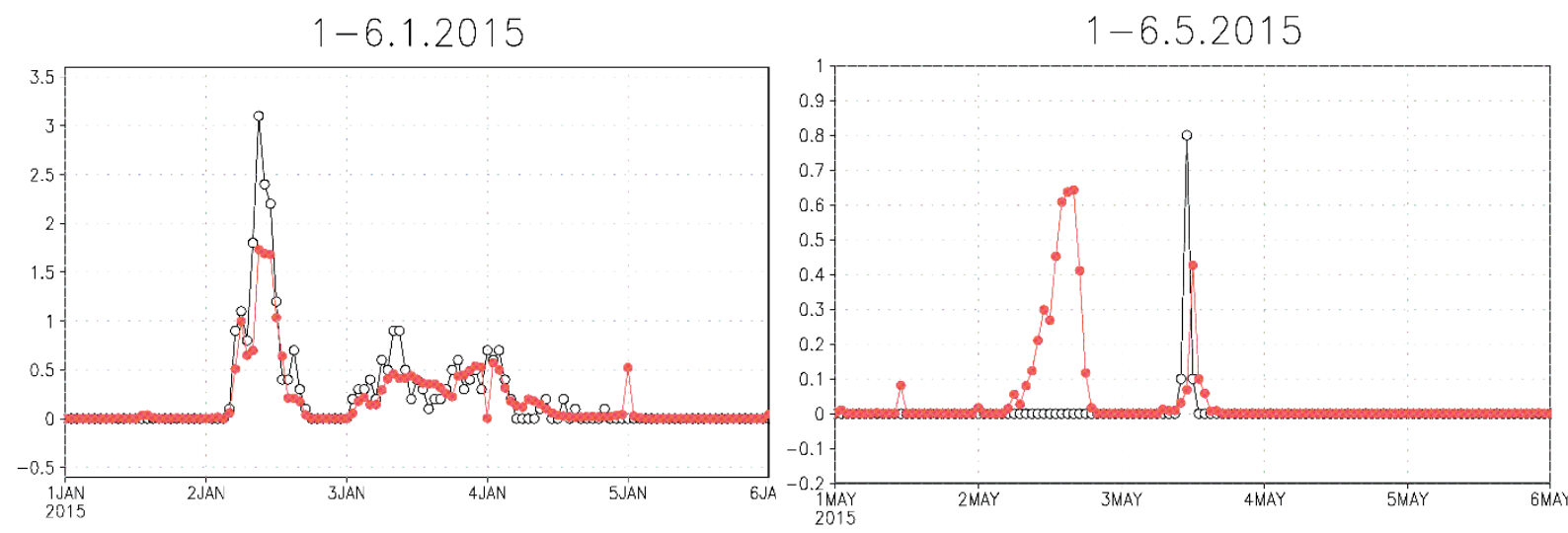

Kuva L2.5: Tunnittaisia sademääriä Jokioisissa tammikuun (yläkuva) ja toukokuun (alakuva) 1-6. päivinä vuonna 2015. Musta käyrä esittää havaintoasemalla mitattuja sademääriä, punainen ERA5-analyysin sademääriä havaintoasemaa lähimmässä hilapisteessä. Yksikkö mm/tunti.

Kuvan L2.5 esimerkit osoittivat, että uusanalyysien tuottamat sademäärät eivät läheskään täydellisesti vastaa havaittuja. Eri tavoin määrättyjen sademäärien tilastollisia ominaisuuksia on vertailtu yksityiskohtaisemmin taulukossa L2.3. Siitä nähdään, että aivan sateettomia tunteja on ollut ERA-analyyseissa ainoastaan noin puolet siitä mitä niitä on havaittu. Vastaavasti hyvin heikkoja sateita esiintyy analyyseissa aivan liian paljon. Kohtalaisten ja heikonpuoleisten sateitten (0.08-3.05 mm/h) esiintymisessä erot eivät ole kovin suuria. Sen sijaan suuria sademääriä esiintyy ERA5-analyyseissa jälleen selvästi liian harvoin. Esimerkiksi sellaisia tunteja, joina satoi 3.05-10.05 mm, oli havaintojen mukaan v. $201519 \mathrm{kpl}$ mutta ERA5-analyysien perusteella vain $5 \mathrm{kpl}$. Yli $10 \mathrm{~mm}: \mathrm{n}$ tuntisademääriä ei uusanalyyseista tavattu ensimmäistäkään. 
Taulukko L2.3: Jokioisten v. 2015 tuntisademäärien jakautuminen eri voimakkuusluokkiin. Yhteensä mittaushetkiä oli $365 \times 24=8760$ kappaletta, mutta 52 ajanhetkeltä mittaustietoa ei ollut käytettävissä. ERA5-analyysien sademäärät on laskettu kahdella vaihtoehtoisella menetelmällä: käyttäen havaintoasemaa lähinnä olevaa pistettä ("ERA-LÄH") tai neljän lähimmän hilapisteen avulla lineaarisesti interpoloitua arvoa ("ERA-INT"); käytännössä näitten kahden menetelmän ero on mitättömän pieni. ERA5-analyyseista nollasademäärien luokkaan on sisällytetty myös sellaiset tapaukset, joissa ilmoitettu sademäärä oli olemattoman pieni (alle miljoonasosamillimetri tunnissa).

\begin{tabular}{crrr}
\hline $\begin{array}{c}\text { Voimakkuus } \\
(\mathrm{mm} / \mathrm{h})\end{array}$ & MITATTU & $\begin{array}{r}\text { ERA- } \\
\text { LÄH }\end{array}$ & $\begin{array}{r}\text { ERA- } \\
\text { INT }\end{array}$ \\
\hline 0 & 7279 & 3902 & 3635 \\
$<0.08$ & 0 & 3119 & 3381 \\
$0.08-0.25$ & 755 & 906 & 915 \\
$0.25-1.05$ & 518 & 699 & 702 \\
$1.05-3.05$ & 136 & 129 & 122 \\
$3.05-10.05$ & 19 & 5 & 5 \\
$>10.05$ & 1 & 0 & 0 \\
\hline
\end{tabular}

Sademäärien tilastollisten jakaumien eroavaisuudet ovat periaatteessa järkeenkäypiä. Uusanalyysi pyrkii kuvaamaan keskimääräistä sademäärää koko hilaruudun alueella, jonka koko tarkasteltavalla alueella on n. $400 \mathrm{~km}^{2}$. Tämä vähentää sekä täysin poutaisia tilanteita että kovia sademääriä; onhan selvästi todennäköisempää, että yhdessä pisteessä (esim. Jokioisten havaintoasemalla) on joko täysin sateetonta tai sataa rankasti kuin että näin tapahtuu yht'aikaisesti koko hilaruudun alueella.

Vuoden 2015 kokonaissademäärä Jokioisissa oli mittaustiedon perusteella n. 690 mm. ERA5analyyseista laskettu vastaava kokonaissademäärä oli $760 \mathrm{~mm}$ eli $\mathrm{n}$. $10 \%$ enemmän. Tuntisademäärien (mitattu vs. ERA5) ajallinen korrelaatio oli 0.50. Jos tarkastellaan tuntisademäärien asemesta 12 tunnin sadekertymiä, korrelaatio nousi 0.76:een. Kvalitatiivisesti tarkastellen mitattujen ja ERA5-analyysien sademäärät näyttäisivät sopivan paremmin yhteen talvella kuin kesällä.

\section{L2.5.1 Uusanalyysitietojen hyödyntäminen tunnittaisten sademäärien laskemisessa}

Alustavan suunnitelman mukaan uusanalyysitietoja oli tarkoitus hyödyntää tuntisademäärien laskemisessa seuraavasti:

1. Tunnistetaan aluksi säähavaintotietojen perusteella ne $6 / 12$ tunnin mittaiset ajanjaksot, joitten aikana mahdollisesti on satanut.

2. Lasketaan kunkin tällaisen jakson sadesumma ERA5-analyysista ja määritetään sadekertymien suhdeluku rMITATTU/reRA5. Tässä vaiheessa pyöristetään uusanalyysien tuottamat tuntidademäärät lähimpään kymmenysosamilliin, jolloin hyvin pienet tuntisademäärät tulkitaan nolliksi. Huomattakoon, että myös mitatut sademäärät on ilmoitettu millimetrin kymmenysosan tarkkuudella. 
3. Kerrotaan ERA5-analyysin tuntisademäärät edellisen kohdan suhdeluvulla. Näin jakson aikana saatu kokonaissademäärä säilyy samana kuin mitä on mitattu mutta se jakautuu yksittäisille tunneille siinä suhteessa kuin missä ERA-analyysin sateetkin.

Erikseen mietittäviksi olisivat jääneet ne tapaukset, jolloin mittausten mukaan sadetta on saatu mutta uusanalyysin perusteella kaikki jakson tunnit ovat olleet poutaisia. Jokioisten v. 2015 sademääriä tutkittaessa tällaisia tapauksia löydettiin muutama kappale.

Menetelmä luultavimmin olisi tuottanut ainakin jossakin määrin tasaisemman sademäärän jakauman kuin mitä pitäisi; ts., siinä olisi edelleenkin liian vähän täysin sateettomia ja hyvin kovasateisia tunteja ja vastaavasti heikkoja sateita liian useasti.

Sekä uusanalyysien että aiemmin tässä liitteessä kuvatun, sääilmiöitä koskevien havaintojen hyödyntäminen perustui samaan periaatteeseen: jaetaan mitattu sademäärä niille tunneille, joiden aikana on mahdollisesti satanut. Koska sääilmiöitä koskevien havaintojen hyödyntäminen osoittautui riittävän hyvin toimivaksi, päädyttiin käyttämään sitä. Tarvittaessa uusanalyysejä voisi kuitenkin hyödyntää etenkin tilanteissa, joissa vallitsevan sään mittaustiedot puuttuivat taajaan, kuten Sodankylässä, jossa ne puuttuivat jakson 1989-2018 aikana yhteensä 498 tuntina (luku L2.1). Mainittakoon myös, että rakennusfysikaalisten testivuosien Jokioinen 2004 ja Vantaa 2007 tuntisadetietoja tarkennettiin niitä muodostettaessa säätutkamittausten avulla (Ruosteenoja ym., 2013). 


\section{Liite 3. Energialaskennan testivuosien valinta ja lisävertailuja}

\section{L3.1 Vaihe 1: Energialaskennan testivuosien ehdokaskuukaudet}

Energialaskennan testivuodet valitaan siten, että ne kuvaisivat mahdollisimman tyypillisiä vuosia rakennusten lämmitys- ja jäähdytystarpeen kannalta Suomessa. Energialaskennan testivuosien ehdokaskuukausien valinta koostui useasta vaiheesta:

1. Lasketaan jokaiselle kahdelletoista kalenterikuukaudelle kunkin suureen (lämpötila $T$, vesihöyryn osapaineelle $P$, kokonaissäteily GHI ja tuulen nopeus $W S$ ) vuorokautisten keskiarvojen keskimääräiset (klimatologiset) summafrekvenssijakaumat (pysyvyyskäyrät) $\Phi$ koko pitkäaikaisen säähavaintojen aikasarjan (vuodet 1989-2018) perusteella (esimerkkikuvan L3.1 paksut mustat käyrät).

2. Lasketaan jokaisen vuoden jokaiselle kuukaudelle kunkin suureen vuorokautisten keskiarvojen summafrekvenssijakaumat $F$ (kuvan L3.1 ohuet käyrät).

3. Määritetään summafrekvenssijakaumien poikkeamat pitkäaikaisista keskiarvoista eli ns. Finkelstein-Schafer -parametrin arvot erikseen lämpötilalle $\left(F S_{T}\right)$, vesihöyryn osapaineelle $\left(F S_{P}\right)$, kokonaissäteilylle $\left(F S_{G H I}\right)$ ja tuulen nopeudelle $\left(F S_{W S}\right)$ kyseisenä kuukautena $m(1-$ 12) ja vuonna $y$ (1989-2018):

$$
F S_{(p, y, m)}=\sum_{i=1}^{n}\left|F_{(p, y, m, i)}-\Phi_{(p, m, i)}\right|
$$

missä säämuuttuja $p=T, P, G H I$ tai $W S$ ja $n$ on frekvenssijakauman luokkien $i$ lukumäärä (tässä $n=51$ ). Vuodet, joille erikseen $F S_{T}$ ja erikseen $F S_{G H I}$ olivat pienimmät eri kalenterikuukausina, on esitetty taulukoiden L3.1-L3.4 kahdessa ylimmässä osassa.

4. Lasketaan yhteen Finkelstein-Schaferin parametrit ilman lämpötilalle ja kokonaissäteilylle kyseisenä kuukautena $m$ ja vuonna $y$ painottaen niitä kertoimilla, jotka kuvaavat lämpötilan ja säteilyn merkitystä lämmitys- ja jäähdytysenergian tarpeelle (Jylhä ym., 2011; Kalamees ym., 2012). Säteilyn painokerroin on kaikkina kuukausina 1, kun taas lämpötilan painokerroin $w_{T}$ vaihtelee. Se on lämmityskautena marras-helmikuussa 20, jäähdytyskautena touko-elokuussa 1 ja välikausina maalis-huhtikuussa ja syys-lokakuussa 4.

$$
\sum F S=w_{T} F S_{T}+F S_{G H I}
$$

Kesällä lämpötila ja auringonsäteily vaikuttavat siis yhä paljon rakennusten energiantarpeeseen, mutta lämmitys- ja välikausina lämpötilan painoarvo on suurempi. Koska kosteuden ja tuulen merkitys on selvästi pienempi, niitä ei oteta huomioon vielä tässä vaiheessa.

5. Asetetaan kunakin kalenterikuukautena yhtälön (3.2) mukaiset summat suuruusjärjestykseen ja poimitaan sijaluvuille 1-3 ne kolme vuotta, joina summat ovat olleet pienimmät (taulukoiden L3.1-L3.4 kolmas osa).

6. Lasketaan noille kolmelle ehdokasvuodelle Finkelstein-Schaferin parametrien summat, kun mukaan otetaan myös vesihöyryn osapaine ja tuulen nopeus:

$$
\sum F S=w_{T} F S_{T}+F S_{G H I}+F S_{p}+F S_{W S}
$$

7. Annetaan näille kolmelle ehdokaskuukaudelle uudet sijaluvut yhtälön (3.3) mukaisen summan perusteella. Nämä tulokset on esitetty taulukoiden L3.1-L3.4 alaosassa. 
Taulukko L3.1. Energialaskennan vyöhykkeen I uuden testivuoden ehdokaskuukaudet valittuina Vantaalla vuosina 1989-2018 tehtyjen säähavaintojen perusteella. Ensimmäinen sarake kertoo sijoituksen valinnan eri vaiheissa, ja loput sarakkeet näyttävät vuodet, joilta kukin kuukausi (I: tammikuu, ..., XII: joulukuu) on peräisin. Ylimpänä on esitetty vuorokauden keskilämpötiloille ja globaalisäteilylle laskettuihin FS-parametreihin perustuvat valinnat. Kolmantena on yhtälöön (3.2) ja alimpana yhtälöön (3.3) perustuvat valinnat. Lopulliset valinnat testivuoteen TRY2020 on korostettu (katso taulukko L3.7).

\begin{tabular}{|c|c|c|c|c|c|c|c|c|c|c|c|c|}
\hline Sija & 1 & II & III & IV & $\mathrm{V}$ & $\mathrm{VI}$ & VII & VIII & IX & $x$ & $\mathrm{XI}$ & XII \\
\hline & & & & \multicolumn{5}{|c|}{ Lämpötilan perusteella tehdyt valinnat } & & & & \\
\hline 1 & 1990 & 1998 & 2004 & 2012 & 2005 & 2000 & 1997 & 1991 & 2010 & 2014 & 2006 & 1998 \\
\hline 2 & 2002 & 2004 & 1999 & 2004 & 2008 & 1990 & 1989 & 1995 & 1998 & 2012 & 1989 & 1999 \\
\hline \multirow[t]{2}{*}{3} & 1994 & 1997 & 1993 & 2007 & 2007 & 1998 & 1991 & 2004 & 2003 & 1991 & 1999 & 2014 \\
\hline & & & \multicolumn{7}{|c|}{ Auringon säteilyn perusteella tehdyt valinnat } & & & \\
\hline 1 & 1995 & 1997 & 1990 & 2012 & 2013 & 2005 & 2011 & 2004 & 1989 & 1989 & 2017 & 1998 \\
\hline 2 & 1989 & 1989 & 2004 & 2013 & 1990 & 2000 & 2018 & 2014 & 2018 & 2008 & 1993 & 2017 \\
\hline \multirow[t]{2}{*}{3} & 2012 & 1992 & 1994 & 1998 & 2000 & 2016 & 2002 & 2018 & 2013 & 1993 & 2005 & 2014 \\
\hline & & & & \multicolumn{5}{|c|}{ Yhtälön (2) perusteella tehdyt valinnat } & & & & \\
\hline 1 & 2002 & 1998 & 2004 & 2012 & 2006 & 2000 & 1989 & 2004 & 1998 & 2012 & 2006 & 1998 \\
\hline 2 & 1990 & 2004 & 1999 & 2007 & 2000 & 2005 & 2012 & 1991 & 2010 & 2004 & 1989 & 1999 \\
\hline \multirow[t]{2}{*}{3} & 1994 & 1997 & 2000 & 1994 & 2005 & 2016 & 1997 & 2003 & 2003 & 1991 & 1999 & 2014 \\
\hline & & & & \multicolumn{5}{|c|}{ Yhtälön (3) perusteella tehdyt valinnat } & & & & \\
\hline 1 & 2002 & 1998 & 2004 & 2012 & 2006 & 2005 & 1989 & 2003 & 1998 & 2012 & 2006 & 1998 \\
\hline 2 & 1990 & 2004 & 1999 & 1994 & 2005 & 2000 & 2012 & 2004 & 2010 & 2004 & 1989 & 1999 \\
\hline 3 & 1994 & 1997 & 2000 & 2007 & 2000 & 2016 & 1997 & 1991 & 2003 & 1991 & 1999 & 2014 \\
\hline
\end{tabular}

Taulukko L3.2. Sama kuin taulukko L3.1, mutta vyöhykkeelle II (Jokioinen).

\begin{tabular}{|c|c|c|c|c|c|c|c|c|c|c|c|c|}
\hline Sija & 1 & II & III & IV & $\mathrm{V}$ & $\mathrm{VI}$ & $\mathrm{VII}$ & VIII & IX & $\mathrm{x}$ & $\mathrm{XI}$ & $\mathrm{XII}$ \\
\hline \multicolumn{13}{|c|}{ Lämpötilan perusteella tehdyt valinnat } \\
\hline 1 & 2002 & 1997 & 2004 & 2007 & 2007 & 1998 & 1999 & 1995 & 2010 & 2012 & 2006 & 1998 \\
\hline 2 & 1990 & 1998 & 1999 & 2012 & 2011 & 1990 & 2012 & 1994 & 1998 & 1991 & 2008 & 2003 \\
\hline 3 & 1991 & 2004 & 2003 & 1991 & 2008 & 2001 & 1991 & 1990 & 2012 & 2004 & 1999 & 1999 \\
\hline \multicolumn{13}{|c|}{ Auringon säteilyn perusteella tehdyt valinnat } \\
\hline 1 & 1989 & 1997 & 1994 & 1998 & 1990 & 2000 & 1992 & 2012 & 1998 & 2008 & 2017 & 2004 \\
\hline 2 & 1995 & 1992 & 1990 & 2018 & 1998 & 2016 & 2002 & 2004 & 2015 & 2011 & 2018 & 2011 \\
\hline 3 & 2013 & 2004 & 2014 & 2013 & 2011 & 2003 & 1989 & 1994 & 1997 & 1993 & 2007 & 2014 \\
\hline \multicolumn{13}{|c|}{ Yhtälön (2) perusteella tehdyt valinnat } \\
\hline 1 & 2002 & 1997 & 2004 & 2007 & 2011 & 2000 & 1991 & 1994 & 1998 & 2012 & 2006 & 1998 \\
\hline 2 & 1991 & 1998 & 1999 & 2012 & 2006 & 2016 & 1989 & 2004 & 2010 & 1991 & 2008 & 2003 \\
\hline 3 & 1994 & 2004 & 1997 & 2018 & 2007 & 2005 & 1997 & 1990 & 1997 & 2004 & 1999 & 1999 \\
\hline \multicolumn{13}{|c|}{ Yhtälön (3) perusteella tehdyt valinnat } \\
\hline 1 & 2002 & 1997 & 2004 & 2012 & 2011 & 2005 & 1989 & 1994 & 1998 & 2012 & 2006 & 1998 \\
\hline 2 & 1994 & 1998 & 1999 & 2007 & 2006 & 2000 & 1991 & 1990 & 2010 & 2004 & 2008 & 1999 \\
\hline 3 & 1991 & 2004 & 1997 & 2018 & 2007 & 2016 & 1997 & 2004 & 1997 & 1991 & 1999 & 2003 \\
\hline
\end{tabular}


Taulukko L3.3. Sama kuin taulukko L3.1, mutta vyöhykkeelle III (Jyväskylä).

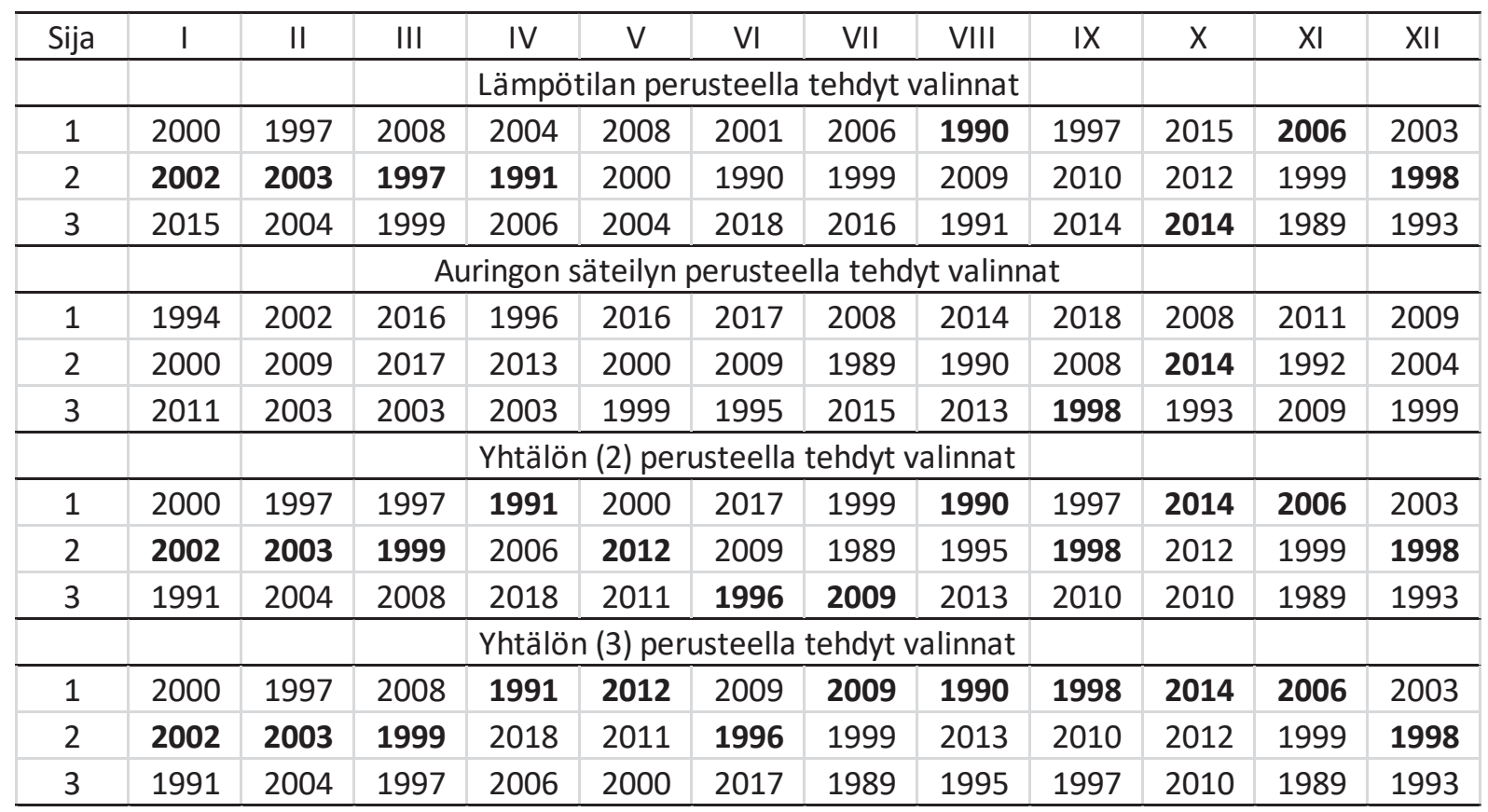

Taulukko L3.4. Sama kuin taulukko L3.1, mutta vyöhykkeelle IV (Sodankylä).

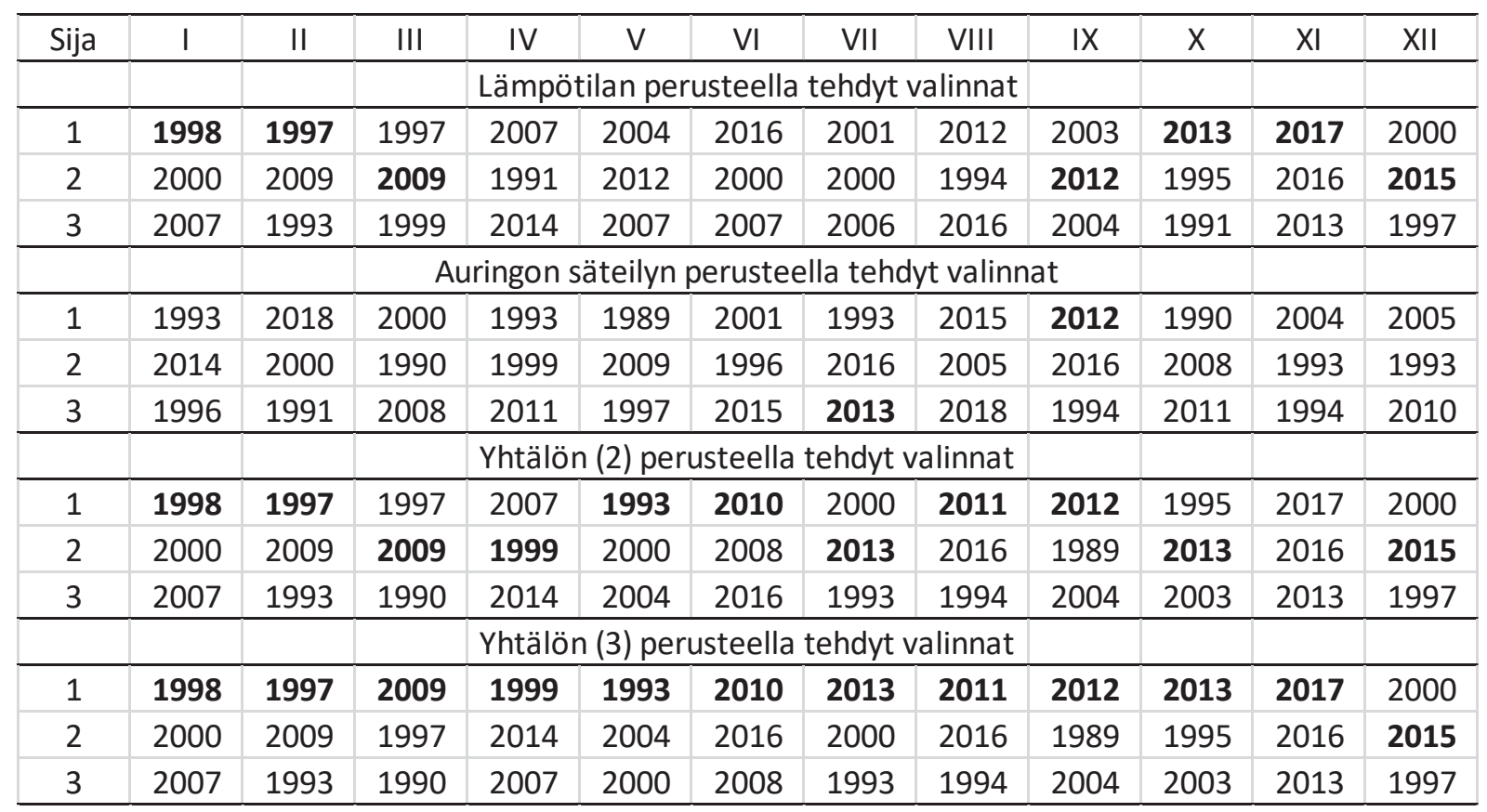



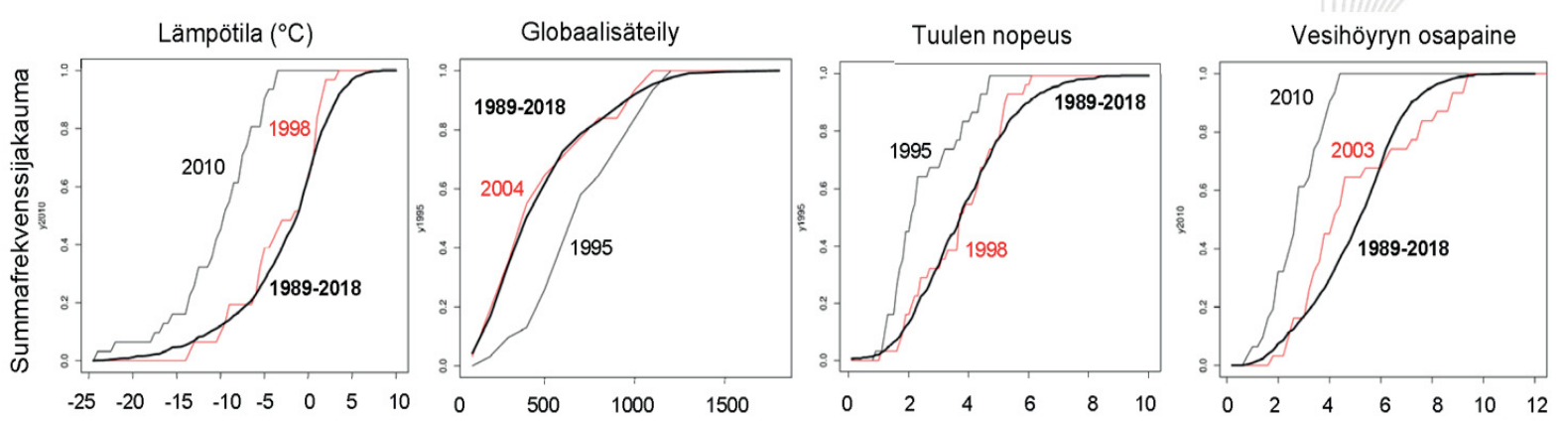

Kuva L3.1: Lämpötilan, kokonnaissäteilyn, vesihöyryn osapaineen ja tuulen nopeuden vuorokautisten keskiarvojen klimatologiset summafrekvenssijakaumat vuosien 1989-2018 perusteella joulukuussa Jokioisissa (paksut käyrät) sekä pienintä (punainen) ja suurinta (ohut musta käyrä) Finkelstein-Schafer -parametrin arvoa vastaavien vuosien joulukuiden summafrekvenssijakaumat. Valituksi testivuoteen TRY2020 tuli vuosi 1998 (taulukko L3.2).

Joulukuuta vyöhykkeellä II esittävässä esimerkkikuvassa L3.1 vuosi 1998 pääsi ensimmäiselle sijalle lämpötilan ja tuulen nopeuden perusteella, kun taas vuosi 2004 olisi ollut paras vaihtoehto auringon kokonaissäteilyn ja vuosi 2003 ilman kosteuden kannalta. Vuoteen 1998 päädytään myös yhtälöiden (3.2) että (3.3) perusteella (taulukko L3.2), mitä pitkälti selittää lämpötilan muita säämuuttujia suurempi merkitys rakennusten energiantarpeen kannalta lämmitys- ja välikausina syyskuusta huhtikuuhun. Toisaalta esimerkiksi vyöhykkeellä I tammikuussa vuosi 2002 (taulukko L3.1) ja vyöhykkeellä IV syyskuussa vuosi 2012 (taulukko L3.4) ovat vasta toisella sijalla lämpötilan FS-parametria tarkasteltaessa, mutta painotetun lämpötilan ja säteilyn FS-parametrien summan (yhtälö 3.2) nojalla ne nousivat ensimmäisiksi ja pitivät kärkisijansa myös, kun huomioon otettiin lisäksi tuulen nopeus ja kosteus (yhtälö 3.3).

Etenkin kesäaikaan valintoihin ovat vaikuttaneet myös tuulen nopeuden ja kosteuden tilastolliset jakaumat, mikä on hyvä pitää mielessä etenkin, jos testivuoden kuukausia säätietoineen käytetään muihinkin tarkoituksiin kuin kuvaamaan rakennusten lämmitys- ja jäähdytystarpeen kannalta tyypillisiä sääoloja. Esimerkiksi vyöhykkeellä III toukokuussa yhtälön (3.3) perusteella parhaaksi ehdokkaaksi noussut vuosi ei mahtunut kolmen parhaan joukkoon pelkästään lämpötilan eikä pelkästään säteilyn kannalta, ja samoin kävi heinäkuussa. Myöskään kesäkuussa ei kolmen lopullisen ehdokkaan joukossa ollut yhtään vuotta, jolloin lämpötilan FSparametri olisi ollut sijoilla 1-3 (taulukko L3.3).

\section{L3.2 Vaihe 2: Energialaskennan testivuosien lopulliset valinnat}

Taulukoiden L3.1-L3.4 alaosassa on siis esitetty energialaskennan testivuosien ehdokkaat muokatun FS-parametrien painotetun summan (yhtälö 3.3) perusteella. Samoin kuin tehtiin testivuotta TRY2012 muodostettaessa (Jylhä ym., 2011; Kalamees ym., 2012), ensimmäiselle sijalle päässyttä vuotta ei kuitenkaan automaattisesti valittu. Tässä työssä lopulliseen valintaan kolmen ehdokkaan välillä vaikuttivat tilastollisia jakaumia kuvaavien FS-parametrien lisäksi aritmeettiset kuukausikeskiarvot ja keskihajonnat sekä pyrkimys välttää liian suuria keinotekoisia säätilojen muutoksia kuukausien vaihteessa, kuten seuraavassa kerrotaan. 
Sen varmistamiseksi, että lopulliset TRY2020-vuoteen valittavat säätiedot ovat sekä tilastollisilta jakaumiltaan että kuukausikeskiarvoiltaan mahdollisimman keskimääräisiä, asetettiin seuraava ehto:

$$
\frac{\left|\overline{p_{y, m}}-\overline{p_{30 v, m}}\right|}{\sigma_{p, 30 v, m}} \leq c_{p, m}
$$

missä säämuuttuja $p=T, P$, GHI tai $W S$, kuukausi $m=1-12$, vuosi $y=1-3$ (ehdokkaat taulukoissa L3.1-L3.4), 30v tarkoittaa jaksoa 1989-2018 ja aksenttiviiva aritmeettista keskiarvoa, $\sigma$ $=30$-vuotisjakson kuukausikeskiarvojen keskihajonta ja $c=$ säämuuttujasta ja kuukaudesta riippuva vakio. Toisin sanoen tarkasteltiin ehdokaskuukausien säätiedoista laskettujen kuukausikeskiarvojen ja vastaavien ilmastollisten keskiarvojen erotuksia ottamalla huomioon myös kyseisen muuttujan kuukausikeskiarvojen vaihtelevuus vuodesta toiseen. Tavoitteena oli varmistaa, että testivuoteen TRY2020 tehtävät valinnat olisivat keskimääräisiä myös perinteisessä ilmastollisessa mielessä eli verrattuna keskihajonnoilla normitettuihin 30vuotisiin aritmeettisiin keskiarvoihin.

Vakiot $c_{p, m}$ määritettiin erikseen lämmitys-, jäähdytys- ja välikausille siten, että ne olisivat mahdollisimman pieniä, mutta kuitenkin riittävän isoja, jotta jäljelle jäisi kullekin kuukaudelle vähintään yksi ehdokas. Tässä työssä päädyttiin iteratiivisesti taulukossa L3.5 esitettyihin arvoihin. Valitut raja-arvot ovat tiukimmat lämpötilalle ja jäähdytyskaudella myös säteilylle.

Taulukko L3.5: Yhtälössä (3.4) käytetyt, iteratiivisesti määritetyt arvot vakiolle c c,m lämmitys-, jäähdytys- ja välikausina.

\begin{tabular}{lrrrrr}
\hline Vuodenaika & Kuukausi & $\mathrm{T}$ & $\mathrm{GHI}$ & $\mathrm{RH}$ & $\mathrm{WS}$ \\
\hline Lämmityskausi & $1-2,11-12$ & 0.3 & 1.3 & 1.5 & 1.5 \\
Välikausi & $3-4,9-10$ & 0.5 & 0.8 & 1.5 & 1.5 \\
Jäähdytyskausi & $5-8$ & 0.6 & 0.6 & 1.5 & 1.5 \\
\hline
\end{tabular}

Ehdon (3.4) läpäisivät kaikki vyöhykkeen I ensimmäiselle sijalle päässeet ehdokkaat. Samoin kävi vyöhykkeellä IV lukuun ottamatta joulukuuta, jonka ensimmäisen sijan ehdokas hylättiin, koska sille tuulen nopeuden kuukausikeskiarvo poikkesi pitkän ajan keskiarvoista enemmän kuin kahden keskihajonnan verran. Vyöhykkeellä II ensimmäisen sijan ehdokas pudotettiin pois helmikuussa suhteellisen kosteuden ja lokakuussa säteilyn poikkeavuuden takia. Vyöhykkeellä III näin kävi tammikuussa lämpötilan, maaliskuussa säteilyn ja joulukuussa tuulen nopeuden takia. Toisen ja kolmannen sijan ehdokkaille vastaavia hylkäyksiä tapahtui selvästi useammin kuin kärkisijan ehdokkaille (miinusmerkit vuosiluvun edessä myöhemmin esitettävässä taulukossa L3.7).

Testivuosien laadinnan viimeinen vaihe koskee kuukausien vaihteiden epäjatkuvuuksia, joita vääjäämättä syntyy, kun kuukausien säähavainnot ovat peräisin eri vuosilta. Vaikka kuukausien vaihteiden osuus kaikista testivuoden tunneista on pieni, säätilan porrasmaiset hyppäykset siirryttäessä kuukaudesta toiseen voivat olla hankalia monien sovellusten kannalta. Niinpä rakennusten energialaskennan säätietojen muodostamista koskevassa, suomalaiseksi kansalliseksi standardiksi vahvistetussa eurooppalaisessa standardissa (SFS EN ISO 15927-4, 2005) lukee: 
"Adjust the parameters in the last eight hours of each month and the first eight hours of the next month by interpolation to ensure a smooth transition when the "best" months are joined to form the reference year. This adjustment shall include the last eight hours of December and the first eight hours of January so that the reference year can be used repeatedly in simulations."

Kuukausien vaihteiden käsittelyä on tässä työssä jossain määrin muutettu verrattuna siihen, miten toimittiin muodostettaessa testivuotta TRY2012 (Jylhä ym. 2011; Kalamees ym., 2012). Epäjatkuvuusongelman ratkaisu oli tuolloin se, että lämpötiloihin kahdeksan tuntia ennen ja jälkeen kuukauden vaihteen sovitettiin kuudennen asteen polynomisovitus, jos lämpötilan ero klo 23 ja 00 välillä ylitti tilastojen perusteella määritetyt kynnysrajat (taulukko L3.6). Jos lämpötilan muutos kuukauden vaihtuessa oli erityisen suuri, muokattuja tunteja oli vielä enemmän, 17-25. Lisäksi suhteelliset kosteudet tasoitettiin lineaarisesti interpoloimalla niille tunneille, joille lämpötilan arvoa oli muokattu.

Taulukko L3.6: Lämpötilojen ja suhteellisten kosteuden muutos kello 23 ja 00 välillä 30 vuoden (1980-2009) aikana tehtyjen havaintojen perusteella. Alaraja vastaa frekvenssijakaumien prosenttipistettä 2.5 ja yläraja 97.5. Niiden väliin osuu $95 \%$ havainnoista. Lähde: Jylhä ym. (2011: taulukko 5.10).

\begin{tabular}{lrrr}
\hline Lämpötila $\left({ }^{\circ} \mathrm{C}\right)$ & Vantaa & Jyväskylä & Sodankylä \\
\hline Alaraja & -1.3 & -1.6 & -1.9 \\
Yläraja & 0.6 & 0.7 & 1.0 \\
\hline Suhteellinen kosteus (\%-yks) & & & \\
\hline Alaraja & -3 & -2 & -3 \\
Yläraja & 7 & 8 & 9 \\
\hline
\end{tabular}

Taulukossa L3.6 esitettyjä kynnysrajoja hyödynnettiin myös tässä työssä. Ennen tasoitusten tekemistä niitä käytettiin testivuoden kuukausien lopullisiin valintoihin. Tarkasteltavana oli se, kuinka suuria lämpötilan ja suhteellisen kosteuden epäjatkuvuuskohtia ilmeni yhtälön (3.4) mukaisen kriteerin läpäisseiden ehdokaskuukausien välillä. Tyypillisesti lämpötila laskee ja suhteellinen kosteus nousee kohti keskiyötä, joten taulukon L3.6 ylä- ja alarajat ovat epäsymmetriset nollan suhteen. Jos lämpötilan tai kosteuden porrasmainen muutos tunnin aikana (klo 23 ja 00 välillä) oli enemmän kuin 16-kertainen verrattuna taulukon ala- ja ylärajoihin, pyrittiin löytämään toinen ehdokaskuukausien yhdistelmä kuitenkin ensimmäisen ja toisen sijan ehdokkaita suosien. Subjektiivinen valinta 16 perustui siihen, että ISO-standardin mukaan tasoitus tehdään 16 tunnin ajalle. Toinen vaihtoehto olisi määrittää 2.5 ja 97.5 prosenttipisteet klo 16 ja klo 8 välisille eroille (ottaen myös vuodenajat huomioon), sillä tasoitus tehtiin näiden ajankohtien välillä.

Käytännössä pyrkimys välttää liian suuria keinotekoisia säätilojen muutoksia kuukausien vaihteessa johti siihen, että vyöhykkeen III helmikuun ja kesäkuun säätiedot otettiin toisen sijan ehdokasvuodelta kärkisijan asemesta. Syynä kesäkuun vaihdokselle oli se, että muutoin toukoja kesäkuun vaihteen lämpötilan nousu tunnin aikana olisi ollut $12.6{ }^{\circ} \mathrm{C}$ eli 18 -kertainen verrattuna taulukossa L3.6 esitettyyn ylärajaan (suhteellinen kosteuskin olisi pienentynyt 29\%yksikköä). Vastaava jyrkkä muutos olisi tullut myös tammi- ja helmikuun vaihteeseen. Muina kuukausina ja muilla vyöhykkeillä porrasmaiset muutokset eivät olleet yhtä suuria, eikä niillä ollut vaikutuksia testivuoden TRY2020 lopullisiin valintoihin. 
Taulukkoon L3.7 on koottu taulukoissa L3.1-L3.4 esitetyt valinnan loppusuoralle päässeet vuodet kuukausittain. Lopulliset valinnat testivuoteen TRY2020 on varjostettu. Kuten aiemmin on kerrottu, miinusmerkki vuosiluvun edessä tarkoittaa, että kyseisenä kuukautena suureiden kuukausikeskiarvot erosivat 30-vuotiskeskiarvoista sallittua (yhtälö 3.4) enemmän. Kaarisuluin on puolestaan merkitty ne ensimmäisen sijan ehdokkaat, jotka hylättiin liian jyrkkien kuukauden vaihteiden takia. Nähdään, että useimmissa tapauksissa valituksi tuli vuosi, joka oli paras myös muokatun ISO-standardin mukaan (yhtälö 3.3). Eniten poikkeamia tästä oli Jyväskylässä. Valittujen joukossa ei kuitenkaan ollut yhtään kolmannen sijan vuotta.

Taulukko L3.7: Energialaskennan testivuoden TRY2020 ehdokaskuukaudet vyöhykkeillä I-IV. Lopulliset valinnat on varjostettu. Miinusmerkki vuosiluvun edessä tarkoittaa, että kyseisenä kuukautena suureiden kuukausikeskiarvojen erot 30-vuotiskeskiarvoista, keskihajonnalla normitettuina, eivät läpäisseet loppuvaiheen valinnassa käytettyjä, vuodenajasta riippuvia kriteerejä (yhtälö 4). Kaarisuluin on puolestaan merkitty ne kärkiehdokkaat, jotka hylättiin liian jyrkkien kuukauden vaihteiden erojen takia.

\begin{tabular}{|c|r|r|r|r|r|r|r|r|r|r|r|r|r|}
\hline Vantaa & I & II & III & IV & V & VI & VII & VIII & IX & X & XI & XII \\
\hline 1 & 2002 & 1998 & 2004 & 2012 & 2006 & 2005 & 1989 & 2003 & 1998 & 2012 & 2006 & 1998 \\
\hline 2 & -1990 & 2004 & 1999 & -1994 & -2005 & 2000 & 2012 & 2004 & -2010 & 2004 & 1989 & 1999 \\
\hline 3 & 1994 & -1997 & -2000 & -2007 & 2000 & 2016 & -1997 & 1991 & 2003 & -1991 & -1999 & 2014 \\
\hline & & & & & & & & & & & & \\
\hline Jokioinen & I & II & III & IV & V & VI & VII & VIII & IX & X & XI & XII \\
\hline 1 & 2002 & -1997 & 2004 & 2012 & 2011 & 2005 & 1989 & 1994 & 1998 & -2012 & 2006 & 1998 \\
\hline 2 & 1994 & 1998 & 1999 & -2007 & 2006 & -2000 & 1991 & 1990 & -2010 & 2004 & -2008 & 1999 \\
\hline 3 & -1991 & 2004 & -1997 & 2018 & 2007 & -2016 & -1997 & 2004 & 1997 & -1991 & -1999 & -2003 \\
\hline
\end{tabular}

\begin{tabular}{|c|r|r|r|r|r|r|r|r|r|r|r|r|}
\hline Jyväskylä & I & II & III & IV & V & VI & VII & VIII & IX & X & XI & XII \\
\hline 1 & -2000 & $\{1997\}$ & -2008 & 1991 & 2012 & $\{2009\}$ & 2009 & 1990 & 1998 & 2014 & 2006 & -2003 \\
\hline 2 & 2002 & 2003 & 1999 & 2018 & 2011 & 1996 & 1999 & 2013 & -2010 & 2012 & -1999 & 1998 \\
\hline 3 & 1991 & 2004 & -1997 & 2006 & -2000 & -2017 & 1989 & -1995 & -1997 & 2010 & 1989 & -1993 \\
\hline
\end{tabular}

\begin{tabular}{|c|r|r|r|r|r|r|r|r|r|r|r|r|}
\hline Sodankylä & I & II & III & IV & V & VI & VII & VIII & IX & X & XI & XII \\
\hline 1 & 1998 & 1997 & 2009 & 1999 & 1993 & 2010 & 2013 & 2011 & 2012 & 2013 & 2017 & -2000 \\
\hline 2 & 2000 & 2009 & -1997 & 2014 & -2004 & 2016 & 2000 & -2016 & -1989 & 1995 & 2016 & 2015 \\
\hline 3 & 2007 & -1993 & 1990 & -2007 & 2000 & 2008 & 1993 & -1994 & -2004 & 2003 & 2013 & 1997 \\
\hline
\end{tabular}

\section{L3.3 Vaihe 3: Testivuosien kuukausien liittäminen yhteen}

Lopuksi suoritettiin kuukauden vaihteiden tasoitus. Toisin kuin TRY2012:ä laadittaessa, nyt on otettu kunkin testivuoteen valitun kuukauden (ns. tyyppikuukauden) ensimmäisten ja viimeisten kahdeksan tunnin säädatan lisäksi huomioon kutakin tyyppikuukautta edeltäneen todellisen kuukauden viimeiset tunnit, samoin kuin sitä seuraavan historiallisen kuukauden ensimmäiset tunnit. Näin kullekin kuukauden vaihteelle (klo 16-8) on kaksi rinnakkaista säädataa: ajallisesti jatkunut historiallinen ja tyyppikuukauden säätiedot. Kuukauden vaihteen lopulliset tunnittaiset säätiedot on muodostettu näistä painotettuina keskiarvoina (painot kellonajasta riippuen). 
Esimerkiksi joulu-tammikuun vaihde klo 00 vyöhykkeellä I on siis tammikuiden 1998 ja 2002 klo 00 säätietojen keskiarvo (katso taulukko L3.7). Joulukuun viimeisen päivän klo 20 tasoitettua arvoa laskettaessa on samaan kellonaikaan joulukuussa 1998 tehdylle havainnolle annettu paino 0.75 ja joulukuun 2001 vastaavalle havainnolle paino 0.25 . Tammikuun ensimmäisen päivän klo 4 arvo on puolestaan laskettu saman kellonajan säätiedoista tammikuussa 1999 ja 2002 antaen edelliselle painon 0.25 ja jälkimmäiselle painon 0.75 .

Tasoitukset on tehty, mikäli lämpötila ja/tai suhteellinen kosteus muuttuivat testivuoden tyyppikuukausien vaihteessa klo 23 ja 00 välillä jyrkemmin kuin mitä tapahtui 30 vuoden havaintojen mukaan 95 prosentissa tapauksista (taulukko L3.6). Käytännössä tasoitus on tehty lähes jokaiselle kuukauden vaihteelle. Samalla on tehty tasoitukset myös tuulen nopeudelle. Sen sijaan auringon säteilylle tasoituksia ei tehty, vaikka kesällä yöttömän yön aikaan etenkin Sodankylässä se olisi saattanut olla paikallaan. Huomattakoon, että sademäärät eivät ole mukana energianlaskennan testivuosien sääaineistoissa.

\section{L3.4: Lisävertailuja testivuoteen TRY2012}

Lisäyksenä luvussa 2.3 tehtyihin vertailuihin testivuosien TRY2012 ja TRY2020 välillä esitetään kuvissa L3.2-L3.3 vielä vastaavat vertailut vyöhykkeille II ja III.
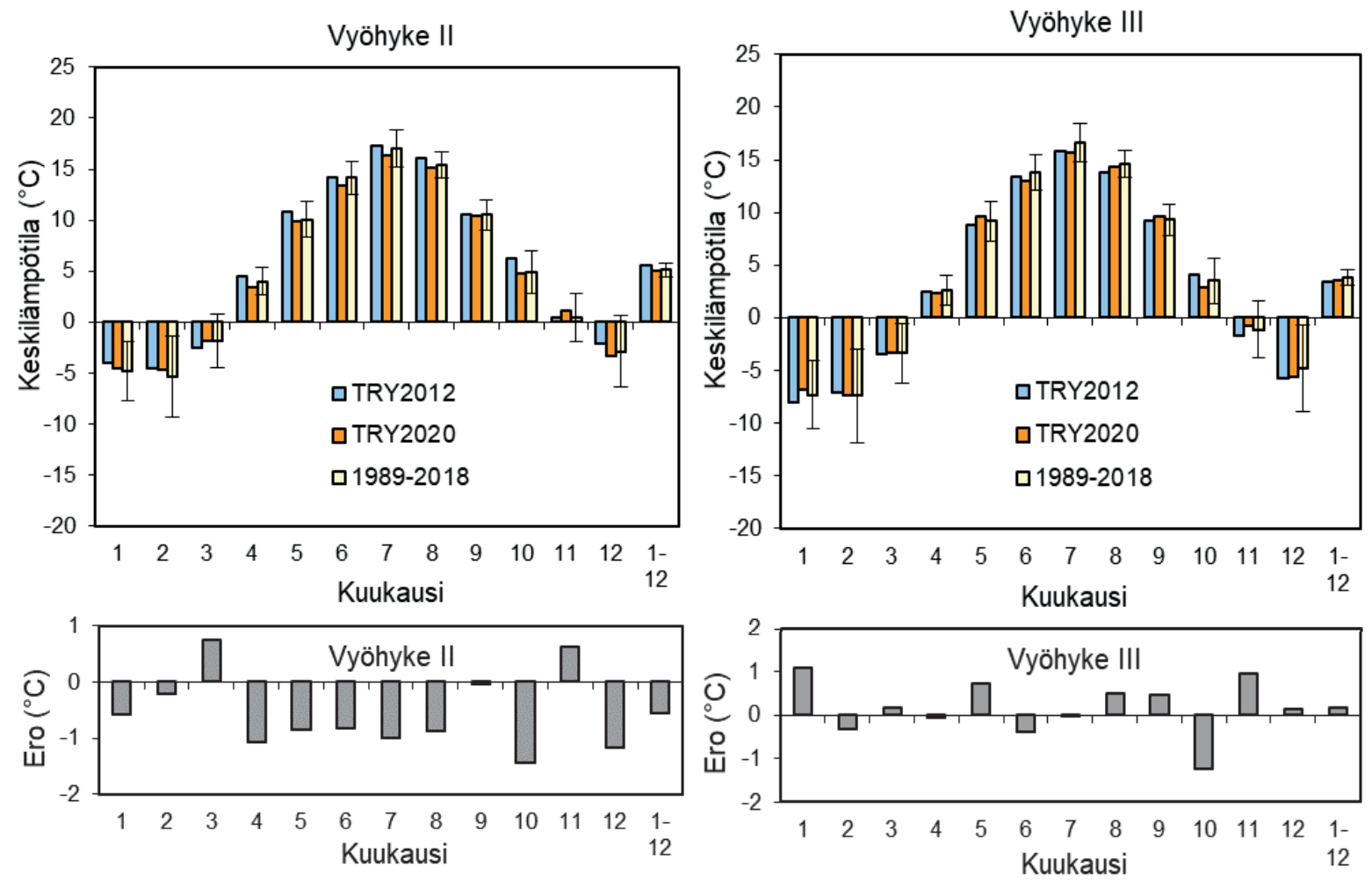

Kuva L3.2: Uuden testivuoden TRY2020 vertailua testivuoteen TRY2012 vyöhykkeillä II-III: kuukausien ja koko vuoden keskilämpötila. Lisäksi on esitetty jakson 1989-2018 pitkäaikaiset keskiarvot sekä yhden keskihajonnan suuruiset poikkeamat siitä kylmään ja lämpimään suuntaan. Vuoden keskilämpötila esitetään pylväillä "1-12". Huomaa, että vyöhykkeellä II TRY2012 perustuu Vantaan eikä Jokioisten mittauksiin. Alemmalla rivillä on testivuosien erotukset (TRY2020-TRY2012). 

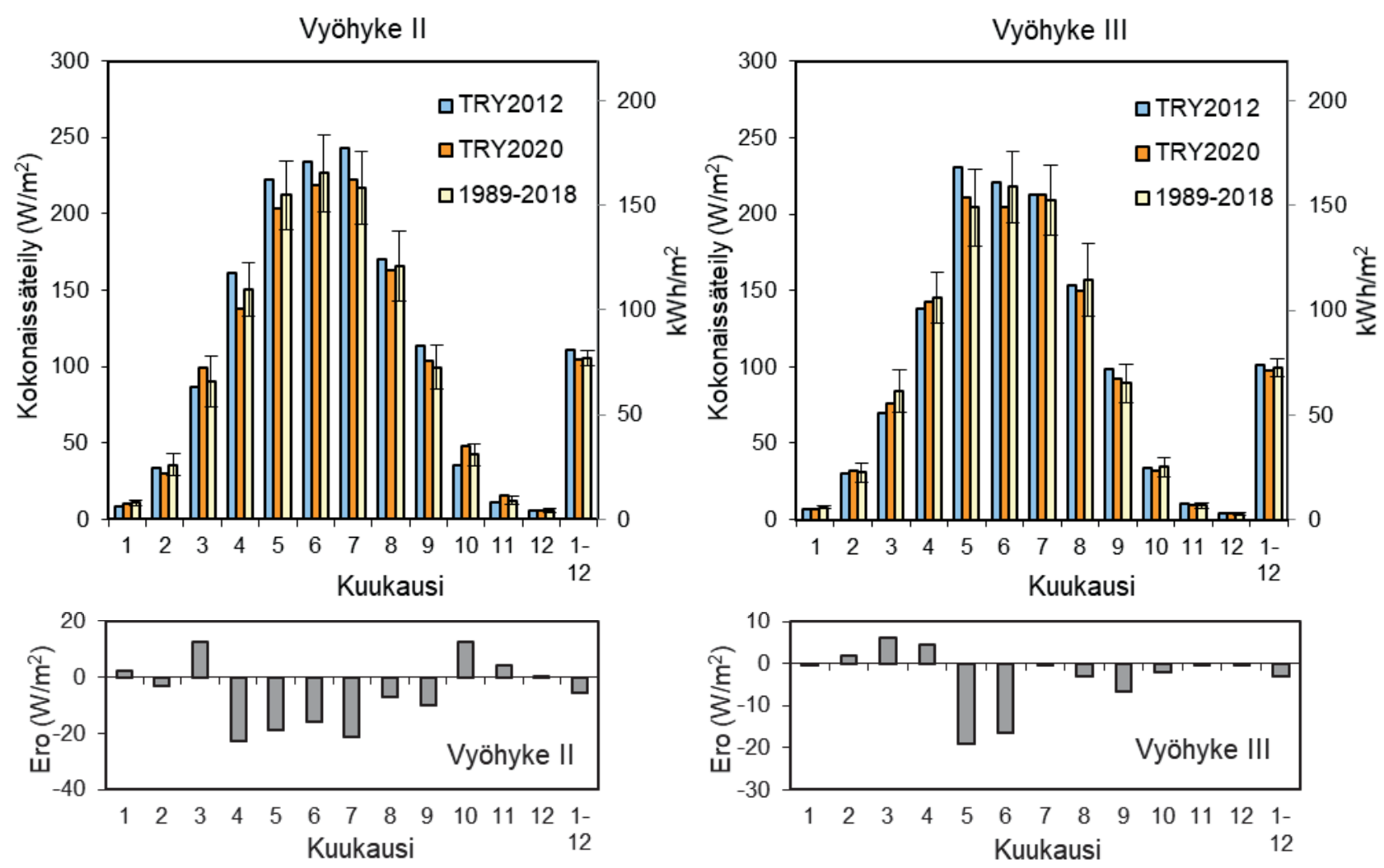

Kuva L3.3: Sama kuin kuva L3.2, mutta auringon kokonaissäteilylle. 


\section{Liite 4. Eri ilmastosuureitten muuntaminen kuvaamaan tulevaisuuden ilmastoa}

Muunnettaessa säähavaintotietoja kuvaamaan tulevaa ilmastoa käytettiin laskentamenetelmiä, jotka on kuvattu yksityiskohtaisesti aiemmin energialaskennan testivuoden TRY2012 ja rakennusfysikaalisten testivuosien (Jokioinen 2004 ja Vantaa 2007) laadintaa käsitelleissä raporteissa (Jylhä ym., 2011; Ruosteenoja ym., 2013). Muunnoksen lähtökohtana toimivat 30vuotisjakson 1989-2018 havaintotiedot (luku 2.1). Mallien ennustamat kuukausikeskiarvojen muutokset haettiin kutakin mittausasemaa lähimpänä sijaitsevasta maailmanlaajuisen $2.5 \times 2.5$ asteen hilaruudukon pisteestä. Soveltuvin osin hyödynnettiin aikaisemmissa tutkimuksissa tehtyjä laskelmia: keskilämpötila ja -sademäärä sekä auringonsäteilyn määrä - Ruosteenoja ym. (2016); suhteellinen kosteus — Ruosteenoja ym. (2017); keskimääräinen tuulivektori ja skalaarinen tuulen nopeus - Ruosteenoja ym. (2019). Toki aiemmin tehtyjä laskelmia jouduttiin päivittämään, sillä nyt käytetään sekä vertailujaksona että tulevaisuuden tarkastelujaksoina eri kausia kuin noissa mainituissa tutkimuksissa. Sadepäivien lukumäärän, sateen intensiteetti-indeksin ja lämpötilan vaihtelujen keskihajonnat muutokset oli laskettava erikseen varta vasten tätä tutkimusta varten.

Useimpien meteorologisten suureitten kuukausikeskiarvoille oli käytettävissä enimmillään 28 ilmastomallin avulla simuloituja jatkuvia aikasarjoja aina vuoteen 2099 asti (taulukko L4.1). Vuosia 2030, 2050 ja 2080 ympäröiviä 30-vuotisjaksoja 2015-2044, 2035-2064 ja 2065-2094 kuvaavat muutokset saatiin tällöin laskettua suoraan näistä aikasarjoista, käyttäen mallitulosten painotettua keskiarvoa. Painot oli määrätty niin, että mikään yksittäinen tutkimuskeskus ei saanut suurempaa yhteenlaskettua painojen summaa kuin 2 (Ruosteenoja, 2016).

Lämpötilojen vaihtelun keskihajonta, tuulen komponentit sekä sadepäivien lukumäärä ja sateen intensiteetti-indeksi piti laskea mallien tuottamien päivittäisten tietojen avulla, joita oli analysoitu vain muutamalta erilliseltä ajanjaksolta. Näihin suureisiin liittyvät ilmastomalleihin perustuvat lähtötiedot (ns. pakotefunktiot) tässä hankkeessa käytetyille ajanjaksoille jouduttiin sen tähden laskemaan osaksi ajan suhteen interpoloimalla. 
Taulukko L4.1: Ilmastonmuutoslaskelmissa käytetyt maailmanlaajuiset ilmastomallit. Kahdessa ensimmäisessä sarakkeessa on annettu mallin nimi ja alkuperämaa. Sen jälkeen on luetteloitu, mitä ilmastosuureita laskettaessa mitäkin mallia on käytetty tietojen lähteenä. Tarkastellut suureet ovat keskilämpötila (T $\left.T_{\text {kesk}}\right)$, lämpötilan vaihtelun keskihajonta $\left(T_{\text {haj}}\right)$, keskimääräinen sademäärä (Sade), sadepäivien lukumäärä ja sateen intensiteetti-indeksi (Sadeind), auringon kokonaissäteily (GHI); Vkesk — keskimääräinen tuulennopeus; $V_{\text {komp - }}$ tuulen komponentit; $R H$ - suhteellinen kosteus.

\begin{tabular}{|c|c|c|c|c|c|c|c|c|c|}
\hline Malli & Alkuperämaa & Tarkas & uureet & & & & & & \\
\hline MIROC5 & Japani & $T_{\text {kesk }}$ & $T_{h a j}$ & Sade & Sadeind & GHI & $V_{k e s k}$ & $V_{\text {komp }}$ & $\mathrm{RH}$ \\
\hline MIROC-ESM & Japani & $T_{k e s k}$ & $T_{h a j}$ & Sade & & GHI & $V_{k e s k}$ & $V_{\text {komp }}$ & $\mathrm{RH}$ \\
\hline $\begin{array}{l}\text { MIROC-ESM- } \\
\text { CHEM }\end{array}$ & Japani & $T_{\text {kesk }}$ & $T_{h a j}$ & Sade & & GHI & $V_{\text {kesk }}$ & & $\mathrm{RH}$ \\
\hline MRI-CGCM3 & Japani & $T_{k e s k}$ & $T_{h a j}$ & Sade & & GHI & $V_{k e s k}$ & $V_{k o m p}$ & $\mathrm{RH}$ \\
\hline BCC-CSM1-1 & Kiina & $T_{k e s k}$ & $T_{h a j}$ & Sade & & GHI & $V_{k e s k}$ & $V_{\text {komp }}$ & $\mathrm{RH}$ \\
\hline INMCM4 & Venäjä & $T_{k e s k}$ & $T_{h a j}$ & Sade & & GHI & $V_{k e s k}$ & $V_{\text {komp }}$ & $\mathrm{RH}$ \\
\hline NorESM1-M & Norja & $T_{\text {kesk }}$ & $T_{h a j}$ & Sade & & GHI & & & $\mathrm{RH}$ \\
\hline NorESM1-ME & Norja & $T_{k e s k}$ & & Sade & & GHI & & & $\mathrm{RH}$ \\
\hline HadGEM2-ES & Britannia & $T_{k e s k}$ & $T_{h a j}$ & Sade & Sadeind & GHI & $V_{k e s k}$ & $V_{\text {komp }}$ & $\mathrm{RH}$ \\
\hline HadGEM2-CC & Britannia & $T_{\text {kesk }}$ & $T_{h a j}$ & Sade & & GHI & $V_{k e s k}$ & $V_{\text {komp }}$ & $\mathrm{RH}$ \\
\hline MPI-ESM-LR & Saksa & $T_{k e s k}$ & $T_{h a j}$ & Sade & & GHI & $V_{k e s k}$ & $V_{\text {komp }}$ & \\
\hline MPI-ESM-MR & Saksa & $T_{\text {kesk }}$ & $T_{h a j}$ & Sade & Sadeind & GHI & $V_{k e s k}$ & $V_{\text {komp }}$ & \\
\hline CNRM-CM5 & Ranska & $T_{\text {kesk }}$ & $T_{h a j}$ & Sade & Sadeind & GHI & $V_{k e s k}$ & $V_{\text {komp }}$ & $\mathrm{RH}$ \\
\hline IPSL-CM5A-LR & Ranska & $T_{\text {kesk }}$ & $T_{h a j}$ & Sade & & GHI & $V_{\text {kesk }}$ & $V_{\text {komp }}$ & $\mathrm{RH}$ \\
\hline IPSL-CM5A-MR & Ranska & $T_{k e s k}$ & $T_{h a j}$ & Sade & & GHI & $V_{\text {kesk }}$ & $V_{\text {komp }}$ & $\mathrm{RH}$ \\
\hline CMCC-CM & Italia & $T_{\text {kesk }}$ & $T_{h a j}$ & Sade & & GHI & $V_{k e s k}$ & $V_{\text {komp }}$ & \\
\hline CMCC-CMS & Italia & $T_{\text {kesk }}$ & $T_{h a j}$ & Sade & & GHI & $V_{k e s k}$ & $V_{\text {komp }}$ & \\
\hline GFDL-CM3 & Yhdysvallat & $T_{\text {kesk }}$ & $T_{h a j}$ & Sade & Sadeind & GHI & $V_{\text {kesk }}$ & $V_{\text {komp }}$ & $\mathrm{RH}$ \\
\hline GFDL-ESM2M & Yhdysvallat & $T_{k e s k}$ & $T_{h a j}$ & Sade & & GHI & $V_{\text {kesk }}$ & $V_{\text {komp }}$ & $\mathrm{RH}$ \\
\hline GISS-E2-R & Yhdysvallat & $T_{k e s k}$ & & Sade & & GHI & $V_{k e s k}$ & & $\mathrm{RH}$ \\
\hline GISS-E2-H & Yhdysvallat & $T_{\text {kesk }}$ & & Sade & & GHI & $V_{k e s k}$ & & $\mathrm{RH}$ \\
\hline NCAR-CCSM4 & Yhdysvallat & $T_{\text {kesk }}$ & $T_{h a j}$ & Sade & Sadeind & GHI & & & $\mathrm{RH}$ \\
\hline $\begin{array}{l}\text { NCAR-CESM1- } \\
\text { CAM5 }\end{array}$ & Yhdysvallat & $T_{k e s k}$ & & Sade & & GHI & $V_{k e s k}$ & & $\mathrm{RH}$ \\
\hline $\begin{array}{l}\text { NCAR-CESM1- } \\
\text { BGC }\end{array}$ & Yhdysvallat & $T_{\text {kesk }}$ & & Sade & & GHI & & & $\mathrm{RH}$ \\
\hline CanESM2 & Kanada & $T_{\text {kesk }}$ & $T_{h a j}$ & Sade & Sadeind & GHI & $V_{k e s k}$ & $V_{\text {komp }}$ & $\mathrm{RH}$ \\
\hline ACCESS1-0 & Australia & $T_{\text {kesk }}$ & $T_{h a j}$ & Sade & & GHI & $V_{k e s k}$ & & RH \\
\hline ACCESS1-3 & Australia & $T_{k e s k}$ & & Sade & & GHI & $V_{k e s k}$ & & $\mathrm{RH}$ \\
\hline EC-EARTH & Usea maa & $T_{\text {kesk }}$ & $T_{h a j}$ & Sade & & GHI & $V_{k e s k}$ & & \\
\hline
\end{tabular}

\section{(a) Lämpötila}

Kaikkien tarkasteltujen ilmastomallien tulosten mukaan keskilämpötilat kohoavat tulevaisuudessa jokaisena vuodenaikana. Samalla kuitenkin talvipuolella vuotta lämpötilan vaihtelu päivästä toiseen vaimenee. Jotta tulevaisuuden lämpötila-aikasarjoja laadittaessa 
saataisiin otettua huomioon molemmat ilmiöt, tunnittaiset lämpötilat ( $\left.T_{\text {ske }}\right)$ vuosien 2030, 2050 ja 2080 ilmastoa kuvaavien 30-vuotisjaksojen aikana laskettiin muokkaamalla jakson 19892018 tunnittaisia lämpötilahavaintoja:

$$
T_{\text {ske }}(t)=T_{\text {hav }}(t)+\Delta \bar{T}+\left(\frac{\sigma_{T, s k e}}{\sigma_{T, n y k}}-1\right)\left(T_{\text {hav }}(t)-\bar{T}_{\text {hav }}\right)
$$

missä $t$ on aika tunteina, $T_{\text {hav }}$ havaintoihin perustuva hetkellinen lämpötila ja $\Delta \bar{T}$ ilmastomallien ennustama keskilämpötilan nousu suhteessa jakson 1989-2018 simuloituun keskilämpötilaan tarkasteltavana kalenterikuukautena. $\sigma_{T, n y k}$ ja $\sigma_{T \text {,ske }}$ ovat mallien simuloimat vuorokauden keskilämpötilojen keskihajonnat kunakin kuukautena perusjakson (1989-2018) ja tulevan jakson (esim. 2035-2064) aikana, ja $\bar{T}_{\text {hav }}$ kertoo kunkin kalenterikuukauden keskilämpötila jakson 1989-2018 säähavainnoista laskettuna. Kaavaa (4.1) käyttäen tuotetuista aikasarjoista lasketut kuukausikeskilämpötilojen muutokset eri kasvihuonekaasuskenaarioille määräytyvät suoraan kaavaan sijoitetun malleihin perustuvan lämpötilamuutoksen perusteella.

Lämpötilan päivittäisistä vaihteluista oli käytettävissä tietoa neljältä jaksolta: 1981-2010, 2010-2039, 2040-2069 ja 2070-2099. Tässä tutkimuksessa tarkasteltuja jaksoja varten keskihajonnat arvioitiin interpoloimalla hajonnan arvoa ajallisesti lähimpien tarjolla olevien jaksojen perusteella.

\section{(b) Suhteellinen kosteus}

Tulevaisuuden ilmaston tunnittaiset suhteellisen kosteuden arvot laskettiin aiemmin kehitetyn iterointialgoritmin avulla (Jylhä ym., 2011, kaava (L10.1)). Syöttötietona annettava kuukauden keskimääräisen kosteuden muutos laskettiin tutkimalla ilman kyllästysvajauksen muuttumista perusjakson ja tulevaisuuden ilmaston välillä. Lisäksi tarvittiin myös tietoa perusjakson ajan keskimääräisestä kuukausikeskilämpötilasta ja suhteellisesta kosteudesta. Nämä laskettiin perusjakson tunnittaisista säähavaintotiedoista.

Säähavainto-ohjeistuksen mukaan suhteellinen kosteus ilmaistaan aina nestemäisen, pakkasasteilla siis alijäähtyneen, veden suhteen. Sen tähden veden suhteen lasketut tulevan ilmaston tunnittaiset kosteusarvot sopeutettiin lopuksi vastaamaan uusia hetkellisiä lämpötiloja niin, että suhteellinen kosteus jään suhteen on se mitä iteroinnin tuloksena saatiin. Tätä suhteellista kosteutta (näennäisesti) kohottavaa korjausta tarvittiin ainoastaan lämpötilan ollessa pakkasen puolella.

\section{(c) Tuuli}

Tuulen suuntaa ja nopeutta muuttuneessa ilmastossa arvioitiin niinikään käyttäen samoja laskentakaavoja kuin aiemmin (Jylhä ym., 2011: liite 10). Tuloksena saatavat tuulen skalaarisen nopeuden kuukausikeskiarvojen muutokset vastaavat tarkkaan malliennustuksia. Myös tuulen suuntien mallitetut muutokset saadaan otettua huomioon, joskin vain likimääräisesti.

Tuulien muutoksia laskettaessa tarvitaan jokaiselle kalenterikuukaudelle ilmastomalleista saatavana tietona (i) keskimääräisen skalaarisen tuulen nopeuden muutos prosentteina ja (ii) tuulen keskimääräisen länsi- ja eteläkomponentin muutos metreinä sekunnissa. 
Tuulen keskimääräisen voimakkuuden prosentuaaliset muutokset saatiin laskettua suoraviivaisesti tuulen voimakkuuksien 30 vuoden liukuvien keskiarvojen aikasarjoista:

$$
D V=\frac{\Delta V(t)-\Delta V(t=2004)}{1+\Delta V(t=2004) / 100}
$$

Missä $\Delta V$ kuvaa tuulen voimakkuuden muuttumista prosentteina verrattuna jakson 1981-2010 keskiarvoon. Lausekkeen alakerrassa oleva (käytännössä pieni) korjaustermi tarvitaan, jotta saataisiin laskettua tarkasti oikein prosenttimuutos nimenomaan vuotta 2004 ympäröivään 30vuotisjaksoon (jakso 1989-2018) nähden. Ilmastonmuutoshan on ehtinyt muuttaa tuulia pikkuisen jo ennen tätä jaksoa.

Mallien simuloimaa tietoa päivittäisistä tuulista RCP4.5- ja RCP8.5-skenaarioilla oli analysoituna vain neljältä 30-vuotisjaksolta (1971-2000, 2020-2049, 2040-2069 ja 20702099; Ruosteenoja ym., 2019). Kunkin kalenterikuukauden keskimääräiset tuulen länsi- ja eteläkomponenttien muutokset vuosien 2030, 2050 ja 2080 ilmastoille laskettiin siksi samaan tapaan ajallisesti interpoloiden kuin tehtiin lämpötilan vaihtelujen keskihajonnallekin.

Lopuksi määrättiin tuulen komponenttien muutokset RCP2.6-skenaariolle kertomalla RCP4.5skenaariota vastaavat muutokset suhdeluvulla

$$
\Delta T_{r c p 2.6}^{g l o b} / \Delta T_{r c p 4.5}^{g l o b}
$$

missä $\Delta T^{g l o b}$ on mallien tuottama maapallon keskilämpötilan muutos jakson 1989-2018 ja tarkasteltavan jakson välillä. Kyseessä on yleisesti käytetty skaalausmenetelmä, joka olettaa, että tarkasteltavan suureen paikallinen muutos on verrannollinen maapallon keskilämpötilan muutokseen.

\section{(d) Auringon säteily}

Muunnettaessa auringon säteilyä kuvaamaan tulevaisuuden ilmastoa tarvittiin pakotteena ainoastaan auringon kokonaissäteilyn muutos prosentteina ilmaistuna. Se laskettiin samalla tavalla kuin esimerkiksi tuulen nopeuden muutos kaavassa (4.2).

\section{(e) Sademäärä}

Muunnettaessa tunnittaisia sademääriä kuvaamaan tulevaa ilmastoa tarvitaan mallien tuottamaa tietoa kolmen sadesuureen muutoksista:

- keskimääräinen kuukausisademäärä

- $\quad$ sadepäivien (sademäärä $\geq 1 \mathrm{~mm} /$ vrk) osuus kaikista päivistä

- $\quad$ sateen intensiteetti-indeksi - keskimääräinen sademäärä kuukauden niinä päivinä, joina on satanut vähintään $1 \mathrm{~mm}$

Laskettiin ensin näitten suureitten muutokset mallien tuloksista. Keskimääräisen sademäärän muutos laskettiin prosentteina samalla tavalla kuin tuulen voimakkuuden ja auringon säteilyn prosenttimuutokset (kaava (4.2)). 
Sadepäivien lukumäärälle ja intensiteetti-indeksille käytettiin laskennan pohjana ns. kvantiilikorjausmenetelmällä (Räty ym., 2014) tuotettuja harhasta korjattuja vuorokautisia mallitietoja, joita oli saatavilla ainoastaan seitsemästä mallista (taulukko L4.1). Kyseisiä mallitietoja ovat aiemmin käyttäneet mm. Lehtonen ym. (2016a, 2016b, 2019b) ja Räihä (2018).

Näiden laskelmien jälkeen muodostettiin arvio tulevaisuuden tunnittaisista sademääristä useassa vaiheessa. Ensin vähennettiin tai lisättiin yli yhden millimetrin sadepäivien osuutta sen mukaisesti, mitä ilmastomallit ennakoivat. Sitten kuukausisademäärän ennustettu kasvu jaettiin sadepäivien ja lopulta sateisten tuntien kesken; ei kuitenkaan tasaisesti, vaan korottaen suuria vuorokausi- ja tuntisateita enemmän kuin pieniä. Lopuksi vielä varmistettiin, että kokonaissademäärä oli muuttunut prosentuaalisesti juuri sen verran kuin mallit ennustavat. Menetelmän yksityiskohtaisempi kuvaus on esitetty Ruosteenojan ym. (2013) raportin liitteessä 1; katso myös Lehtosen ym. (2014b) artikkelia. 


\section{Liite 5. Ilmastosuureitten kuukausikeskiarvojen muutokset 30-vuotisista aikasarjatiedostoista}

Eri ilmastosuureitten muutokset siirryttäessä tulevaan ilmastoon tuotettiin liitteessä 4 esitetyillä algoritmeilla. Tuloksena saadut suureitten muutokset kaikilla neljällä asemalla on esitetty taulukossa L5.1. Poikkeuksena tästä on tuulen suunta, joka on esitetty asteina. Sen tähden siitä ei ole mielekästä laskea aikakeskiarvoja. Tuulen suuntien jakaumasta esitetään sen sijaan frekvenssijakaumia kappaleessa 3.3.

Taulukko L5.1: (a) Kuukauden keskilämpötilan, (b) tunnittaisten lämpötilojen keskihajonnan, (c) suhteellisen kosteuden, (d) tuulen nopeuden, (e) kokonaissäteilyn, (f) auringon sädettä vastaan kohtisuoralle pinnalle osuvan suoran säteilyn, (g) vaakasuoralle pinnalle lankeavan hajasäteilyn ja (h) sademäärän muutosten kuukausikeskiarvot kaikilla neljällä havaintopaikkakunnalla siirryttäessä jaksosta 1989-2018 vuosien 2030, 2050 ja 2080 tienoilla vallitsevaan RCP4.5-skenaariota vastaavaan ilmastoon. Sädettä vastaan kohtisuoralle pinnalle projisoitua suoraa säteilyä ei ole laskettu auringon paistaessa alempaa kuin viiden asteen korkeudelta, mikä selittää taulukon L5.1(f) puuttuvat arvot pohjoisessa joulukuussa.

(a) Lämpötilan muutos $\left({ }^{\circ} \mathrm{C}\right)$

\begin{tabular}{|c|ccc|ccc|ccc|ccc|}
\hline & \multicolumn{3}{|c|}{ Vantaa } & \multicolumn{3}{c|}{ Jokioinen } & \multicolumn{3}{c|}{ Jyväskylä } & \multicolumn{3}{c|}{ Sodankylä } \\
\hline Kk & 2030 & 2050 & 2080 & 2030 & 2050 & 2080 & 2030 & 2050 & 2080 & 2030 & 2050 & 2080 \\
\hline 1 & 1.6 & 2.4 & 3.5 & 1.5 & 2.3 & 3.2 & 1.8 & 2.7 & 3.9 & 2.1 & 3.1 & 4.4 \\
2 & 1.3 & 2.1 & 3.1 & 1.3 & 2.1 & 3.1 & 1.3 & 2.2 & 3.3 & 1.5 & 2.7 & 3.8 \\
3 & 1.3 & 2.1 & 2.8 & 1.3 & 2.1 & 2.8 & 1.3 & 2.2 & 3.0 & 1.4 & 2.5 & 3.3 \\
4 & 1.2 & 1.9 & 2.7 & 1.1 & 1.8 & 2.5 & 1.3 & 2.0 & 2.9 & 1.3 & 2.0 & 3.0 \\
5 & 1.1 & 1.6 & 2.2 & 1.0 & 1.6 & 2.2 & 1.1 & 1.7 & 2.3 & 1.3 & 2.0 & 2.8 \\
6 & 0.9 & 1.5 & 2.0 & 0.9 & 1.5 & 2.1 & 0.9 & 1.5 & 2.0 & 1.0 & 1.6 & 2.2 \\
7 & 0.9 & 1.5 & 2.1 & 1.0 & 1.5 & 2.1 & 0.9 & 1.5 & 2.1 & 1.0 & 1.6 & 2.2 \\
8 & 1.0 & 1.5 & 2.1 & 1.0 & 1.5 & 2.1 & 0.9 & 1.5 & 2.1 & 0.9 & 1.6 & 2.3 \\
9 & 1.0 & 1.5 & 2.1 & 0.9 & 1.4 & 2.1 & 1.0 & 1.5 & 2.1 & 1.0 & 1.6 & 2.3 \\
10 & 0.8 & 1.5 & 2.2 & 0.8 & 1.5 & 2.2 & 0.9 & 1.6 & 2.4 & 1.0 & 1.9 & 2.8 \\
11 & 1.2 & 1.8 & 2.7 & 1.1 & 1.7 & 2.5 & 1.4 & 2.1 & 3.1 & 1.7 & 2.5 & 3.7 \\
12 & 1.3 & 2.1 & 3.0 & 1.2 & 1.9 & 2.7 & 1.5 & 2.4 & 3.5 & 1.7 & 2.9 & 4.0 \\
\hline Vuosi & 1.1 & 1.8 & 2.5 & 1.1 & 1.7 & 2.5 & 1.2 & 1.9 & 2.7 & 1.3 & 2.2 & 3.1 \\
\hline
\end{tabular}

(b) Lämpötilojen keskihajonnan muutos (\%)

\begin{tabular}{|c|ccc|ccc|ccc|ccc|}
\hline & \multicolumn{3}{|c|}{ Vantaa } & \multicolumn{3}{c|}{ Jokioinen } & \multicolumn{3}{c|}{ Jyväskylä } & \multicolumn{3}{c|}{ Sodankylä } \\
\hline $\mathrm{Kk}$ & 2030 & 2050 & 2080 & 2030 & 2050 & 2080 & 2030 & 2050 & 2080 & 2030 & 2050 & 2080 \\
\hline 1 & -6.0 & -10.0 & -15.0 & -7.0 & -11.0 & -16.0 & -6.0 & -10.0 & -15.0 & -6.0 & -9.0 & -14.0 \\
2 & -6.0 & -10.0 & -16.0 & -8.0 & -12.0 & -19.0 & -6.0 & -10.0 & -15.0 & -6.0 & -10.0 & -14.0 \\
3 & -6.0 & -13.0 & -18.0 & -8.0 & -16.0 & -21.0 & -6.0 & -13.0 & -17.0 & -7.0 & -15.0 & -20.0 \\
4 & -4.0 & -6.0 & -8.0 & -4.0 & -7.0 & -9.0 & -3.0 & -5.0 & -7.0 & -6.0 & -8.0 & -11.0 \\
5 & -2.0 & -3.0 & -3.0 & -1.0 & -3.0 & -2.0 & -2.0 & -4.0 & -4.0 & -2.0 & -3.0 & -4.0 \\
6 & -0.1 & 1.0 & -1.0 & 0.0 & 0.0 & -2.0 & -0.0 & 1.0 & -2.0 & -1.0 & 0.0 & -2.0 \\
7 & 1.0 & 1.0 & -1.0 & 0.0 & -1.0 & -2.0 & -0.0 & 1.0 & -0.0 & -1.0 & -0.0 & -3.0 \\
8 & -1.0 & -1.0 & -1.0 & -1.0 & -1.0 & -2.0 & -1.0 & -1.0 & -1.0 & -2.0 & -2.0 & -3.0 \\
9 & 0.0 & -3.0 & -4.0 & -0.0 & -3.0 & -4.0 & -1.0 & -3.0 & -5.0 & -2.0 & -4.0 & -6.0 \\
10 & -3.0 & -4.0 & -7.0 & -3.0 & -5.0 & -7.0 & -4.0 & -5.0 & -8.0 & -5.0 & -7.0 & -9.0 \\
11 & -5.0 & -9.0 & -12.0 & -5.0 & -8.0 & -11.0 & -6.0 & -10.0 & -13.0 & -8.0 & -12.0 & -17.0 \\
12 & -4.0 & -10.0 & -14.0 & -5.0 & -10.0 & -14.0 & -5.0 & -10.0 & -16.0 & -6.0 & -11.0 & -16.0 \\
\hline
\end{tabular}


(c) Suhteellisen kosteuden muutos (\%-yks.)

\begin{tabular}{|c|ccc|ccc|cccc|ccc|}
\hline & \multicolumn{3}{|c|}{ Vantaa } & \multicolumn{3}{c|}{ Jokioinen } & \multicolumn{3}{c|}{ Jyväskylä } & \multicolumn{3}{c|}{ Sodankylä } \\
\hline Kk & 2030 & 2050 & 2080 & 2030 & 2050 & 2080 & 2030 & 2050 & 2080 & 2030 & 2050 & 2080 \\
\hline 1 & 0.4 & 0.4 & 0.8 & 0.7 & 1.0 & 1.5 & 1.0 & 1.5 & 2.2 & 1.5 & 2.3 & 3.3 \\
2 & -0.1 & 0.1 & 0.2 & 0.3 & 0.5 & 0.8 & 0.6 & 1.2 & 1.7 & 1.2 & 2.1 & 2.9 \\
3 & -0.8 & -1.0 & -1.4 & -0.4 & -0.6 & -0.7 & -0.4 & -0.4 & -0.7 & 0.6 & 1.6 & 2.2 \\
4 & -1.1 & -1.8 & -2.0 & -0.7 & -1.1 & -1.0 & -0.9 & -1.7 & -1.9 & -0.8 & -1.3 & -2.4 \\
5 & -0.6 & -1.0 & -0.9 & -0.5 & -0.9 & -0.7 & -0.4 & -0.9 & -0.5 & -1.4 & -2.1 & -2.6 \\
6 & -0.5 & -1.2 & -1.4 & -0.4 & -1.0 & -1.2 & -0.3 & -1.2 & -1.4 & -0.2 & -0.4 & -0.3 \\
7 & -1.1 & -1.5 & -1.9 & -0.8 & -1.1 & -1.3 & -0.7 & -1.1 & -1.9 & -0.2 & -0.4 & -0.6 \\
8 & -1.4 & -1.6 & -2.1 & -1.0 & -1.2 & -1.6 & -0.8 & -1.2 & -1.7 & -0.6 & -0.8 & -1.5 \\
9 & -0.8 & -1.0 & -1.4 & -0.4 & -0.5 & -0.8 & -0.4 & -0.5 & -0.9 & -0.2 & -0.4 & -0.4 \\
10 & -0.0 & -0.0 & 0.0 & 0.0 & 0.1 & 0.2 & 0.1 & 0.3 & 0.4 & 0.2 & 0.5 & 0.8 \\
11 & 0.2 & 0.4 & 0.7 & 0.4 & 0.5 & 0.9 & 0.3 & 0.6 & 1.0 & 1.1 & 1.6 & 2.2 \\
12 & -0.0 & 0.1 & 0.2 & 0.4 & 0.7 & 1.0 & 0.5 & 0.9 & 1.4 & 1.2 & 2.1 & 2.8 \\
\hline Vuosi & -0.5 & -0.7 & -0.8 & -0.2 & -0.3 & -0.2 & -0.1 & -0.2 & -0.2 & 0.2 & 0.4 & 0.5 \\
\hline
\end{tabular}

(d) Tuulen nopeuden \%-muutos

\begin{tabular}{|c|ccc|ccc|cccc|ccc|}
\hline & \multicolumn{3}{|c|}{ Vantaa } & \multicolumn{3}{c|}{ Jokioinen } & \multicolumn{3}{c|}{ Jyväskylä } & \multicolumn{3}{c|}{ Sodankylä } \\
\hline $\mathrm{Kk}$ & 2030 & 2050 & 2080 & 2030 & 2050 & 2080 & 2030 & 2050 & 2080 & 2030 & 2050 & 2080 \\
\hline 1 & 0.5 & -0.5 & -0.8 & 0.6 & -0.2 & -0.6 & 1.5 & 0.9 & 0.0 & 0.2 & 0.1 & -1.9 \\
2 & -1.1 & -1.0 & -2.2 & -0.3 & -0.1 & -1.2 & -0.9 & -0.4 & -1.9 & -1.9 & -2.2 & -2.8 \\
3 & -0.3 & -0.7 & -2.6 & 0.3 & 0.2 & -1.8 & -0.1 & -0.4 & -2.3 & -1.5 & -2.4 & -4.5 \\
4 & -0.7 & -2.0 & -3.0 & -0.1 & -1.4 & -2.6 & -0.2 & -1.4 & -2.7 & -2.0 & -3.3 & -4.8 \\
5 & -0.3 & -1.0 & -1.3 & 0.4 & -0.3 & -0.5 & -0.2 & -0.4 & -0.9 & -0.2 & -0.7 & -0.9 \\
6 & -1.2 & -1.7 & -1.4 & -0.2 & -0.6 & -0.1 & -0.4 & -0.3 & -0.1 & -0.8 & -1.4 & -2.0 \\
7 & 0.6 & 0.0 & -0.3 & 0.7 & 0.6 & 0.2 & 0.7 & 1.0 & 0.5 & -1.5 & -1.7 & -2.6 \\
8 & 0.0 & -0.2 & -1.3 & 0.2 & 0.3 & -0.7 & 0.8 & 0.3 & -0.2 & -1.2 & -2.5 & -2.7 \\
9 & -0.4 & -1.3 & -1.5 & 0.0 & -0.6 & -1.0 & 0.2 & -0.4 & -0.4 & -0.2 & -1.2 & -1.4 \\
10 & -1.8 & -0.9 & -1.7 & -1.1 & 0.2 & -0.5 & -1.4 & -0.7 & -1.3 & -1.7 & -1.5 & -1.4 \\
11 & -0.2 & -0.6 & -1.3 & 0.2 & -0.1 & -0.6 & 1.0 & 0.5 & -0.3 & -0.6 & -1.3 & -1.2 \\
12 & -0.6 & -1.2 & -1.3 & -0.1 & -0.7 & -0.8 & 0.0 & -0.5 & -1.3 & -0.9 & -0.7 & -2.3 \\
\hline Vuosi & -0.5 & -0.9 & -1.6 & 0.0 & -0.2 & -0.9 & 0.1 & -0.2 & -0.9 & -1.0 & -1.6 & -2.4 \\
\hline
\end{tabular}

(e) Kokonaissäteilyn \%-muutos

\begin{tabular}{|c|ccc|ccc|ccc|ccc|}
\hline & \multicolumn{3}{|c|}{ Vantaa } & \multicolumn{3}{|c|}{ Jokioinen } & \multicolumn{3}{c|}{ Jyväskylä } & \multicolumn{3}{c|}{ Sodankylä } \\
\hline Kk & 2030 & 2050 & 2080 & 2030 & 2050 & 2080 & 2030 & 2050 & 2080 & 2030 & 2050 & 2080 \\
\hline 1 & -2.5 & -4.5 & -6.6 & -1.8 & -3.4 & -4.7 & -2.3 & -4.5 & -7.4 & -3.1 & -4.1 & -5.7 \\
2 & -2.2 & -4.1 & -5.1 & -2.0 & -3.6 & -4.4 & -1.6 & -4.0 & -5.5 & -1.7 & -4.1 & -5.2 \\
3 & -1.4 & -2.4 & -3.9 & -1.3 & -2.1 & -3.7 & -1.4 & -3.2 & -4.7 & -1.6 & -3.5 & -4.9 \\
4 & 0.3 & 0.9 & 1.1 & 0.2 & 0.8 & 0.9 & -0.9 & -0.5 & -1.1 & -2.1 & -3.1 & -4.7 \\
5 & 1.2 & 2.0 & 2.1 & 1.1 & 1.8 & 1.9 & 0.9 & 1.8 & 1.5 & -0.4 & -0.6 & -1.1 \\
6 & 0.7 & 1.4 & 1.4 & 0.7 & 1.4 & 1.5 & 0.6 & 1.4 & 1.0 & 0.0 & 0.2 & -0.2 \\
7 & 1.8 & 2.3 & 2.2 & 1.5 & 1.8 & 1.8 & 1.4 & 1.8 & 2.0 & 0.8 & 1.3 & 1.2 \\
8 & 2.6 & 3.0 & 3.8 & 2.3 & 2.5 & 3.5 & 2.2 & 2.6 & 3.2 & 1.7 & 2.2 & 3.0 \\
9 & 3.1 & 3.9 & 5.1 & 2.8 & 3.6 & 4.4 & 2.6 & 3.1 & 3.8 & 0.6 & 1.1 & 1.0 \\
10 & 2.4 & 3.0 & 3.8 & 2.2 & 2.5 & 3.7 & 1.4 & 0.6 & 0.5 & -2.2 & -5.4 & -7.3 \\
11 & -1.5 & -0.9 & -1.7 & -0.3 & 0.7 & 0.6 & -3.6 & -4.7 & -6.8 & -5.4 & -7.6 & -11.4 \\
12 & -2.1 & -3.6 & -4.6 & -0.5 & -1.2 & -2.2 & -2.8 & -4.8 & -7.3 & -5.4 & -8.1 & -11.6 \\
\hline Vuosi & 1.2 & 1.6 & 1.6 & 1.0 & 1.4 & 1.5 & 0.7 & 1.0 & 0.8 & -0.2 & -0.4 & -0.9 \\
\hline
\end{tabular}


(f) Sädettä vastaan kohtisuoralle pinnalle saapuvan suoran säteilyn \%-muutos

\begin{tabular}{|c|ccc|ccc|ccc|ccc|}
\hline & \multicolumn{3}{|c|}{ Vantaa } & \multicolumn{3}{c|}{ Jokioinen } & \multicolumn{3}{c|}{ Jyväskylä } & \multicolumn{3}{c|}{ Sodankylä } \\
\hline Kk & 2030 & 2050 & 2080 & 2030 & 2050 & 2080 & 2030 & 2050 & 2080 & 2030 & 2050 & 2080 \\
\hline 1 & -6.7 & -11.5 & -16.2 & -5.2 & -9.3 & -12.3 & -6.6 & -12.3 & -19.3 & -10.9 & -13.7 & -18.2 \\
2 & -5.0 & -8.9 & -10.9 & -4.5 & -8.0 & -9.4 & -3.8 & -8.7 & -11.7 & -4.7 & -10.1 & -12.6 \\
3 & -2.7 & -4.6 & -7.1 & -2.5 & -3.9 & -6.8 & -2.8 & -6.2 & -9.0 & -3.4 & -7.3 & -9.9 \\
4 & 0.6 & 1.7 & 2.0 & 0.5 & 1.4 & 1.7 & -1.7 & -1.0 & -2.1 & -4.5 & -6.5 & -9.6 \\
5 & 2.0 & 3.3 & 3.5 & 1.9 & 3.1 & 3.2 & 1.6 & 3.1 & 2.7 & -0.9 & -1.3 & -2.3 \\
6 & 1.3 & 2.4 & 2.5 & 1.3 & 2.5 & 2.7 & 1.1 & 2.6 & 1.9 & 0.1 & 0.3 & -0.3 \\
7 & 3.1 & 3.9 & 3.8 & 2.8 & 3.2 & 3.3 & 2.5 & 3.2 & 3.7 & 1.6 & 2.6 & 2.4 \\
8 & 4.7 & 5.5 & 6.9 & 4.3 & 4.7 & 6.5 & 4.2 & 4.9 & 5.9 & 3.7 & 4.6 & 6.5 \\
9 & 6.1 & 7.6 & 9.9 & 5.6 & 7.2 & 9.0 & 5.6 & 6.6 & 8.1 & 1.5 & 2.7 & 2.3 \\
10 & 5.2 & 6.4 & 8.2 & 4.9 & 5.7 & 8.4 & 3.7 & 1.6 & 1.4 & -5.6 & -12.3 & -15.9 \\
11 & -4.1 & -2.5 & -4.6 & -0.8 & 2.4 & 1.9 & -11.5 & -14.3 & -19.4 & -14.5 & -19.4 & -26.8 \\
12 & -6.3 & -10.2 & -12.6 & -1.9 & -4.0 & -7.2 & -10.5 & -17.0 & -24.3 & - & - & - \\
\hline Vuosi & 1.8 & 2.4 & 2.5 & 1.7 & 2.2 & 2.5 & 1.2 & 1.4 & 0.9 & -0.7 & -1.3 & -2.4 \\
\hline
\end{tabular}

(g) Hajasäteilyn \%-muutos

\begin{tabular}{|c|ccc|cccc|ccc|ccc|}
\hline & \multicolumn{3}{|c|}{ Vantaa } & \multicolumn{3}{c|}{ Jokioinen } & \multicolumn{3}{c|}{ Jyväskylä } & \multicolumn{3}{c|}{ Sodankylä } \\
\hline Kk & 2030 & 2050 & 2080 & 2030 & 2050 & 2080 & 2030 & 2050 & 2080 & 2030 & 2050 & 2080 \\
\hline 1 & -1.2 & -2.3 & -3.6 & -0.8 & -1.6 & -2.3 & -1.2 & -2.5 & -4.5 & -3.0 & -4.0 & -5.5 \\
2 & -0.7 & -1.4 & -1.9 & -0.6 & -1.3 & -1.7 & -0.5 & -1.4 & -2.0 & -0.6 & -1.7 & -2.4 \\
3 & -0.2 & -0.4 & -0.7 & -0.2 & -0.3 & -0.7 & -0.1 & -0.4 & -0.8 & -0.2 & -0.7 & -1.1 \\
4 & 0.0 & 0.0 & 0.1 & 0.0 & 0.1 & 0.1 & -0.0 & -0.0 & -0.0 & -0.1 & -0.2 & -0.5 \\
5 & 0.0 & 0.1 & 0.1 & 0.1 & 0.1 & 0.1 & 0.0 & 0.0 & 0.0 & -0.0 & -0.0 & -0.0 \\
6 & 0.0 & 0.0 & 0.0 & 0.0 & 0.1 & 0.1 & 0.0 & 0.0 & 0.0 & 0.0 & 0.0 & -0.0 \\
7 & 0.1 & 0.1 & 0.1 & 0.1 & 0.1 & 0.1 & 0.0 & 0.0 & 0.0 & 0.0 & 0.0 & 0.0 \\
8 & 0.1 & 0.1 & 0.1 & 0.1 & 0.1 & 0.2 & 0.1 & 0.1 & 0.1 & 0.0 & 0.1 & 0.1 \\
9 & 0.2 & 0.3 & 0.4 & 0.3 & 0.3 & 0.4 & 0.1 & 0.1 & 0.1 & 0.0 & 0.1 & 0.0 \\
10 & 0.4 & 0.4 & 0.6 & 0.4 & 0.5 & 0.7 & 0.2 & 0.1 & 0.1 & -0.6 & -2.1 & -3.3 \\
11 & -0.6 & -0.3 & -0.7 & -0.1 & 0.3 & 0.2 & -1.7 & -2.3 & -3.7 & -4.0 & -5.9 & -9.1 \\
12 & -1.2 & -2.1 & -2.7 & -0.3 & -0.7 & -1.3 & -2.6 & -4.4 & -6.9 & -5.4 & -8.1 & -11.6 \\
\hline Vuosi & -0.0 & -0.0 & -0.1 & 0.0 & 0.0 & -0.0 & -0.0 & -0.1 & -0.2 & -0.1 & -0.2 & -0.4 \\
\hline
\end{tabular}

\section{(h) Sademäärän \%-muutos}

\begin{tabular}{|c|ccc|cccc|ccc|ccc|}
\hline & \multicolumn{3}{|c|}{ Vantaa } & \multicolumn{3}{c|}{ Jokioinen } & \multicolumn{3}{c|}{ Jyväskylä } & \multicolumn{3}{c|}{ Sodankylä } \\
\hline Kk & 2030 & 2050 & 2080 & 2030 & 2050 & 2080 & 2030 & 2050 & 2080 & 2030 & 2050 & 2080 \\
\hline 1 & 4.5 & 8.6 & 13.1 & 4.2 & 8.6 & 12.4 & 4.4 & 7.8 & 13.7 & 4.8 & 8.5 & 12.8 \\
2 & 2.9 & 5.5 & 8.4 & 3.5 & 5.3 & 8.2 & 2.0 & 5.4 & 8.2 & 2.8 & 7.9 & 9.3 \\
3 & 3.0 & 7.6 & 9.6 & 3.1 & 7.0 & 9.4 & 3.1 & 6.9 & 8.1 & 2.9 & 6.6 & 8.5 \\
4 & 4.7 & 4.5 & 5.6 & 3.3 & 3.3 & 3.5 & 5.7 & 4.8 & 7.7 & 5.9 & 7.8 & 10.0 \\
5 & 5.4 & 3.3 & 8.6 & 2.2 & 0.1 & 7.1 & 5.3 & 4.8 & 10.4 & 5.2 & 5.6 & 12.5 \\
6 & 2.6 & 5.0 & 6.7 & 4.1 & 6.0 & 7.7 & 3.5 & 3.8 & 7.5 & 4.9 & 5.9 & 7.6 \\
7 & 0.5 & 1.9 & 4.7 & 2.6 & 2.5 & 5.6 & 2.8 & 4.8 & 6.5 & 4.1 & 6.3 & 7.8 \\
8 & -2.7 & -0.4 & 1.1 & -0.4 & 2.7 & 2.7 & -0.3 & 1.5 & 1.9 & 1.4 & 2.8 & 3.6 \\
9 & 1.2 & 1.7 & 2.0 & 2.6 & 3.2 & 3.4 & 1.1 & 3.1 & 4.6 & 4.8 & 4.4 & 7.6 \\
10 & 4.1 & 6.3 & 9.8 & 3.6 & 7.6 & 9.8 & 2.8 & 7.1 & 10.1 & 2.4 & 7.6 & 12.7 \\
11 & 4.3 & 8.1 & 11.0 & 4.6 & 7.9 & 11.7 & 5.4 & 8.1 & 13.3 & 7.2 & 10.5 & 15.5 \\
12 & 5.8 & 8.5 & 13.0 & 5.6 & 8.4 & 13.2 & 5.4 & 7.9 & 12.7 & 7.4 & 10.6 & 15.1 \\
\hline Vuosi & 2.8 & 5.0 & 7.7 & 3.1 & 5.2 & 7.7 & 3.2 & 5.2 & 8.3 & 4.4 & 6.7 & 9.7 \\
\hline
\end{tabular}




\section{Liite 6. Ääriarvojen laskeminen}

Ääriarvolaskenta perustuu ns. yleisen ääriarvojakauman eli GEV-jakauman (General Extreme Value) sovittamiseen 30-vuotisten tunnittaisten sääaikasarjojen vuotuisiin maksimi- (korkea lämpötila, sademäärä, tuulen nopeus) ja minimiarvoihin (alhainen lämpötila). GEV-jakauman sovittamiseen käytettiin tilastollisen laskennan R-ohjelmointikielen ääriarvolaskentaan yleisesti käytettyä extRemes-pakettia (Gilleland ja Katz, 2016). GEV-jakauman parametrien estimointiin käytettiin suurimman uskottavuuden estimointimenetelmää (maximum likelihood estimate).

GEV-jakauman käyttöön liittyvien oletusten mukaisesti aikasarjan, johon jakauma sovitetaan, tulee olla trenditön. Tämän vuoksi aineistoihin sovitettiin lineaarinen regressiomalli ajan suhteen mahdollisen trendin arvioimiseksi. Niissä tapauksissa, joissa lineaarinen trendi oli tilastollisesti merkitsevä $(p<0.05)$, tehtiin regressiomallin residuaalien avulla ns. trendin poisto ennen GEV-jakauman sovittamista.

Aineistoihin sovitetuista GEV-jakaumista määritettiin kunkin suureen toistuvuustasot 2, 5, 10, 20, 50 ja 100 vuoden tilastollisille toistuvuusajoille. Nämä ovat siis esimerkiksi korkeita lämpötiloja tarkasteltaessa ne lämpötilat, jotka saavutetaan tilastollisesti keskimäärin kerran 2, $5,10,20,50$ ja 100 vuodessa. Suurimman uskottavuuden estimaatin lisäksi toistuvuustasoille määritettiin $95 \%$ luottamustasoa vastaavat luottamusvälin ala- ja ylärajat.

Yleisesti ottaen ääriarvolaskenta tuottaa sitä luotettavampia arvioita, mitä pidempi aikasarja on. Jatkossa tässä tutkimuksessa käytetyn 30-vuotisen aikasarja sijasta olisi hyödyllistä käyttää pidempää jaksoa, jolloin myös GEV-jakautuman muotoparametrin (kuten myös toistuvuustasojen) epävarmuus jäisi pienemmäksi. 
FINNISH METEOROLOGICAL INSTITUTE

Erik Palménin aukio 1

P.O. Box 503

FI-O0560 HELSINKI

tel. +358295391000

WWW.FMI.FI

FINNISH METEOROLOGICAL INSTITUTE

REPORTS 2020:6

ISSN 0782-6079

ISBN 978-952-336-128-7 (pdf)

https://doi.org/10.35614/isbn.9789523361287
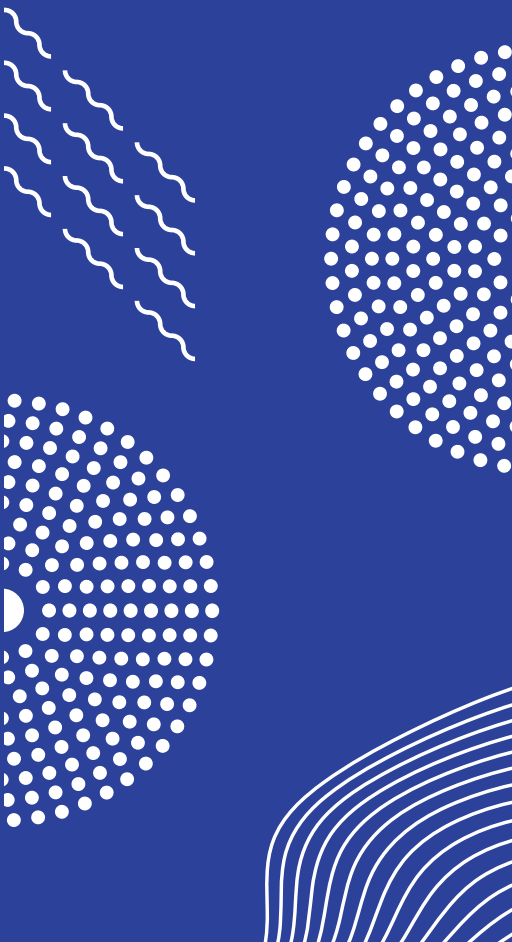